\title{
La aportación de Castro Urdiales \\ a la Armada Invencible (1586-1618)
}

\section{The contribution of Castro Urdiales to the Spanish Armada (1586-1618)}

\author{
Pedro Andrés PORRAS ARBOLEDAS \\ Catedrático acreditado de Historia del Derecho \\ Departamento de Historia del Derecho \\ Instituto de Metodología e Historia de la Ciencia Jurídica \\ Facultad de Derecho. Universidad Complutense de Madrid \\ pporras@der.ucm.es
}

Recibido: 30 de septiembre de 2014

Aceptado: 22 de octubre de 2014

\section{RESUMEN}

Durante al menos 30 años los herederos de los vecinos de Castro Urdiales que habían participado en la Jornada de Inglaterra de 1588 o los propios supervivientes estuvieron reclamando a la Corona el pago de sus salarios como marineros, artilleros o pilotos; gracias a los poderes otorgados por los interesados, donde hicieron constar las peripecias de los castreños en aquella triste ocasión, es posible reconstruir la participación de la villa cántabra en esa y otras armadas de la época.

PALABRAS CLAVE: Castro Urdiales, Jornada de Inglaterra, Armada Invencible, salarios atrasados.

\begin{abstract}
For almost 30 years the heirs of Castro Urdiales neighbors who had participated in the 1588 England Journey, or even the survivors themselves, were claiming to the Crown the payment of their wages as sailors, gunners and pilots. The adventures of Castreños on that sad occasion were recorded in the wills granted by stakeholders, and so it is possible to reconstruct the participation of the Cantabrian town in this and other armies at the time.
\end{abstract}

KEYWORDS: Castro Urdiales, England Journey, Invincible Army, back wages.

\section{RÉSUMÉ}

Pendant près de 30 ans, les voisins de Castro Urdiales qui avaient participé et survécu à la Journée de l'Angleterre en 1588, ou bien leurs héritiers, on laissé entendre à la Couronne leurs prétensions sur les arriérés des salaires encore débités aux marins, artilleurs et pilotes de cette campaigne. Les aventures des Castreños sur cette triste occasion ont été enregistrées sur les pouvoirs loués par les parties prenantes, et grâce à eux il est possible de reconstituer aujourd'hui la participation de la ville cantabrique dans cette armée et dans d'autres à l'époque.

MOTS CLÉ : Castro Urdiales, Journée d'Angleterre, Armée Invincible, arriérés de salaires. 
Mucho se ha escrito sobre la Jornada de Inglaterra de la Gran Armada de Felipe II y seguramente mucho queda aún por escribir, habida cuenta de la importancia del acontecimiento y de los rastros que ha dejado tanto en los archivos nacionales como en otros de rango inferior, como es el caso que nos ocupa. Entre los protocolos de la villa de Castro Urdiales (Cantabria) se conserva una parte importante de los debidos al escribano público García de Peñavera, que, además, reunía la condición de escribano de la armada real en las Cuatro Villas por aquellos años 1587-1589.

Si hubiéramos de ser fieles a la terminología usada por los contemporáneos, deberíamos utilizar las locuciones que he escrito arriba: «Jornada de Inglaterra», esto es, la expedición de la «Gran Armada», sin embargo, el nombre que la posterioridad ha conservado para este hecho de armas, luctuoso para España — «Armada Invencible»—, fue creado en tono de burla por sus enemigos de entonces y, como en nuestro país hemos sido y somos amigos de los disparates proferidos interesadamente por los propagandistas de la Leyenda Negra, seguimos usándolo sin pudor. En mi caso, el hecho de utilizarlo proviene de la evidencia de que en los buscadores de hoy en día las referencias de este artículo serán más localizables si manejo el oprobioso título inventado por los voceros de Isabel I de Inglaterra.

Como es fácil imaginar, es esta una aportación de importancia menor, por cuanto intentaré recoger sólo la información conservada en dichos protocolos sobre la participación de las naves y vecinos de Castro Urdiales y su comarca, sin pretender ir más allá. Como base de partida contamos con los datos reunidos en su día por Javier Echavarría y Sarraoa, que hizo un bonito resumen de esta aportación a partir de la obra del capitán de navío don Cesáreo Fernández Duro y de los mismos protocolos que yo también he manejado. ${ }^{1}$ Más recientemente fue José Luis Casado Soto - tristemente desaparecido este mismo mes- quien se ocupó, a partir de los documentos conservados en el Archivo General de Simancas, de localizar las naves castreñas de la Armada y su destino, si bien no pasó más adelante, por estar más interesado en el tema de la construcción naval y de la tipología de las embarcaciones que en otros. ${ }^{2}$

\footnotetext{
${ }^{1}$ Recuerdos históricos castreños, Santander, 1898, pp. 135-144 (hay edición moderna, Bilbao, 1973). De su mano deben de proceder los gruesos trazos de lápiz rojo o azul en los protocolos en cuestión cuando localiza algún dato relativo a este evento.

La obra clásica se la debemos al citado don Cesáreo (La Armada Invencible, Madrid, 1884-1885, dos tomos), que realizó un acopio ingente de documentación.

Mi búsqueda de esos mismos datos dio lugar a otro trabajo (La práctica mercantil marítima en el Cantábrico Oriental (siglos XV-XIX), Madrid, 2002). Véase la bibliografía ahí reunida.

${ }^{2}$ Los barcos españoles del siglo XVI y la Gran Armada de 1588, Madrid, 1988. Resulta interesante comprobar las conclusiones sobre el supuesto 'desastre' de la Invencible, que minimiza (pp. 253-257); en cualquier caso, sea por las consecuencias de dicha Armada y las que le siguieron de inmediato, sea por la atracción de la foralidad vizcaína o por otra razón, lo cierto es que, cruzado el umbral del siglo XVII, la marina castreña era una sombra de la existente unas décadas antes y no dejó de ir a peor luego.
} 
Así, la obra de conjunto más completa sobre el episodio de 1588 es la de Colin Martin y Geoffrey Parker, donde se puede encontrar un relato detallado de los hechos y muchas otras consideraciones. ${ }^{3}$

La tradición marinera de las poblaciones cántabras debe retrotraerse a la fundación de las grandes villas costeras merced al otorgamiento del Fuero de San Sebastián a la mayor parte de ellas; de este modo, la costa cántabra entró en la Baja Edad Media con una red de villas marineras (Santander, San Vicente de la Barquera, Laredo, Castro Urdiales) que, en buena medida, dominaron el comercio en el Cantábrico, así como la pesca en aguas franco-españolas, irlandesas y de Groenlandia. A partir de finales del siglo XVI — coincidiendo casualmente o no con el desastre de la Gran Armada - dicha pujanza pesquera y mercantil entró en crisis, de la cual salió extraordinariamente beneficiada la marina vizcaína, que contaba desde un siglo antes con el apoyo de un Consulado propio, además de los privilegios de la foralidad.

No pretendo entrar aquí en la polémica de las consecuencias para las villas cántabras de la Jornada de Inglaterra, tan sólo exponer ordenadamente, como decía, la participación de naves y vecinos en dicha Jornada. Para ello contamos con dos grupos de noticias, todas procedentes de los protocolos de Peñavera, principalmente, y de sus sucesores en las escribanías públicas castreñas. En el primer grupo se detallan las actuaciones habidas entre don Ordoño de Zamudio, corregidor de las Cuatro Villas, y don Antonio Hurtado de Mendoza, vecino de Castro Urdiales, encargado de reclutar bajeles y tripulaciones en su villa y alrededores, en las que ambos se acusaban mutuamente del retraso en el cumplimiento de dicha misión. Un segundo conjunto de noticias proceden de los poderes otorgados por los supervivientes o, mejor, por sus causahabientes para cobrar sus salarios atrasados, cobranza que se retrasó, al menos, 30 años en algunos casos, todo ello a pesar de la voluntad de Felipe II de hacer justicia a sus fieles súbditos; ${ }^{4}$ de hecho, muchos de los pagos documentados proceden de los testamentarios del fallecido monarca. ${ }^{5}$

Para Echavarría las armadas de esos años y la peste de 1596-1597, traída de Calais, causaron un tremendo impacto en la villa, que perdió más de 3.000 personas, reduciéndose de 700 a 200 el total de vecinos; como él mismo sentencia, «en el transcurso de veinte años pierde las tres cuartas partes del número de sus hijos, arrebatados por las guerras y por la peste» (op. cit., pp. 153-156; la cita textual en la última). ${ }^{3}$ La Gran Armada. La mayor flota jamás vista desde la creación del mundo, Barcelona, 2011 (ed. original de 1988). La valoración de este episodio es mucho más acerada en estos autores (pp. 412-414). Tanto la bibliografía reunida por Casado Soto como por Martín y Parker me releva de la necesidad de incluirla ahora en estas páginas.

${ }^{4}$ La primera oleada de poderes conservada data de 1594, cuando Juan de Marecheaga, vecino de Castro, recibió el encargo de numerosos interesados en el cobro; los que fueron recibiendo parte de sus atrasos le libraron sus cartas de finiquito en 1596, momento en que tomó el relevo Gaspar de Otañes. A partir de 1609 el encargado de continuar con el cobro fue Martín de Miranda, esta vez no ante la Hacienda real, sino ante don Pedro Mesía de Tovar, caballero de Santiago, del Consejo de Hacienda y contador mayor de dicho Consejo, en su calidad de pagador de los descargos de Felipe II. A la altura de 1617 proseguía dicha labor Gaspar de Carasa.

${ }^{5}$ Martin y Parker destacan el contraste entre la actitud cínica de Isabel I y sus ministros de ahorrarse las 
Con anterioridad a 1587 — por sólo referirnos a la década previa - la marina de Castro Urdiales vio cómo se procedía intermitentemente al embargo real, esto es, a la inmovilización de todas las naves mercantes para atender las necesidades diplomáticas o militares de la Corona: ${ }^{6}$ entre fines de 1571 y comienzos del año siguiente, así como en julio de 1574, se fletaron distintas naves para ir a los Estados de Flandes, concretamente, la zabra San Martín (capitán Martín de Cereceda, vecino de Castro), ${ }^{7}$ los navíos San Pedro y Espíritu Santo y la nao Nuestra Señora la Blanca (dueños Antón de Sámano escribano y Juan de Jimeno) ${ }^{8}$ y la nave en la que había de viajar Juan Sánchez de la Atalaya. ${ }^{9}$ Para 1576 se habían movilizado naves para ir de nuevo a Flandes ${ }^{10}$ y para formar una armada que patrullase la línea costera entre el Reino de Portugal y la provincia de Guipúzcoa. ${ }^{11}$

pagas de sus combatientes fallecidos o heridos y la caritativa del Rey Prudente de atender a las neesidades de sus hombres (pp. 403-406 y 410-415), sin embargo, la realidad que constatamos en nuestros documentos es la dificultad de hallar dinero con que pagar dichos atrasos durante tanto tiempo.

${ }^{6}$ Casado Soto, op. cit., pp. 35-53. También Echavarría, pp. 129-133.

${ }^{7}$ 1570/07/08. Castro Urdiales. El capitán Martín de Cereceda, vecino de Castro, que había fletado su zabra San Martín, surta en el puerto de la villa, al señor Juan Martínez de Recalde, vecino de Bilbao, probehedor de S.M., para yr con ella desde la canal de la villa de Bilbao a los Estados de Flandes con despachos ymportantes al servicio de S.M., y había de llevar para dicho viaje 30 personas; para que así conste, entrega lista pormenorizada de la tripulación (Archivo Histórico Provincial de Cantabria, protocolo 1.694, fol. 28).

1570/10/20. Castro Urdiales. El mismo capitán otorga poder a Juan de Liendo, también vecino, para cobrar de Martín Ruiz de Leriz, pagador en la armada real, estante en Santander, 100 florines (20.000 mrs.), resto de una libranza de 500 florines, que alguien [ilegible] le había librado, tomando razón el contador Navarrete (AHPC, prot. 1.694, fol. 44). El capitán moriría en febrero de 1571, según obligación prestada por sus albaceas (Ibidem, fol. 286-287).

${ }^{8}$ 1571/12/01. Castro Urdiales. Julián de Uribe, en nombre de Octaviano de Encinas, vecino de Burgos, cónsul y diputado por el prior y cónsules de Burgos para el despacho de las naves fletadas por el Consulado, requiere a Antón de Sámano escribano y a Juan de Jimeno, vecinos de Castro, dueños de los navíos San Pedro y Espíritu Santo y de la nao Nuestra Señora la Blanca, surtos en la bahía de Santander, los cuales estaban embargados para la armada real que había de ir a Flandes, y ahora con la venida del Excmo. Sr. Duque de Medinaceli, capitán general y gobernador de Flandes, habían sido desarrestadas para ir a ese viaje; se les había apercibido tres veces par que las proveyesen de gente, vituallas y munición y no lo habían querido hacer. Requeridos ambos, uno responde que tenía que carenar su nave y el otro que no había encontrado aún tripulación (Idem, fol. 205-206).

${ }^{9}$ 1574/07/05. Castro Urdiales. Juan Sáenz de la Atalaya, vecino de Castro, por quanto yo estoy de partida para los Estados de Flandes en la armada del Adelantado Pero Menéndez de Avilés, otorga testamento (AHPC, prot. 1.695, fol. 127-128). En el día hay cierre de cuenta entre este Juan y Antón de la Colina (cuentas, dares y tomares) (Ibidem, fol. 134).

${ }^{10}$ 1576/09/20. Castro Urdiales. Antona de Vidania, viuda de Juan de Manzanal, vecina de Castro, por sí y en nombre de sus hijos, otorga poder a Diego de la Gándara, Alonso de Lastero y Juan de Jimeno, vecinos también y estantes en los Estados de Flandes, para cobrar los sueldos de su marido, como maestre de una de las çabras que pasaron a los dichos Estados, así como para recoger los bienes que allí hubiera dejado (Idem, fol. 432).

${ }^{11}$ 1576/07/22 a 08/11. Castro Urdiales. Relación de los marineros que iban en la nao La Trinidad, maestre Martín de Beasáin, vecino de Castro, con las fechas de embarque (27 personas, tres de ellos con un hijo, detallados) (Idem, fol. 452r). 
La conquista del Reino de Portugal y la valerosa toma de la Isla Tercera, en las Azores, dio oportunidad de lucirse a la marina cántabra, empleada en muchas otras tareas de la monarquía por aquellos años previos a la Invencible. Buen ejemplo de ello fue la hoja de servicios de la zabra La Concepción (parcioneros el matrimonio Diego de Noja Castillo y María de las Suertes, vecinos de Castro):

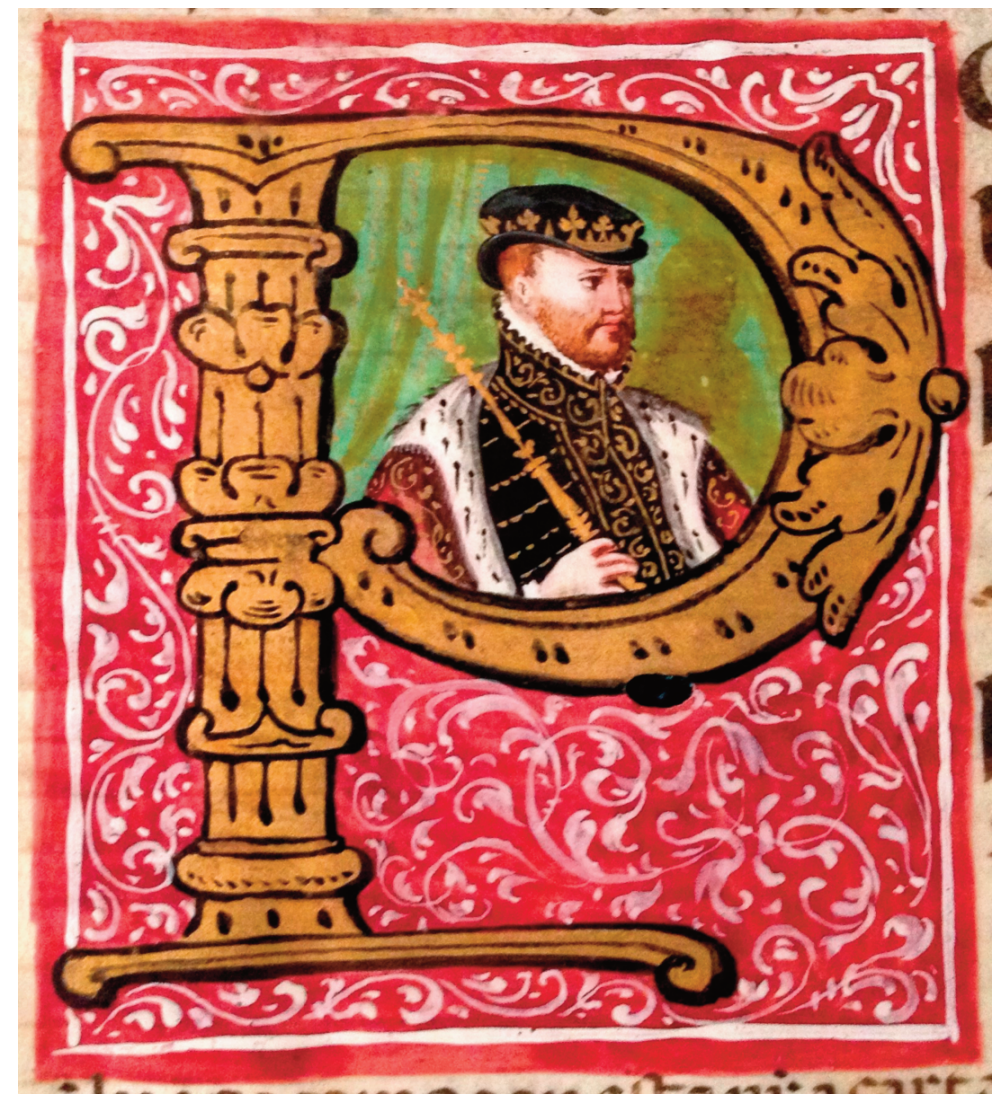

Felipe II en 1565

1576/07/30. Castro Urdiales. San Juan de Santa Cruz, Antón de Sevilla, Domingo de Lastras, Martín de Santa Cruz, Gonzalo de San Juan, Francisco de Ciberio, Gaspar de Avero, Francisco de la Sierra, Juan del Río y Juan del Cerro, vecinos de Castro, que estaban igualados con Sancho de Aparicio, también vecino, capitán y maestre de la zabra Santa María de Castro, surta en la bahía de Santander, para ir de armada de S.M. junto a las otras naos y zabras para la armada de la costa de Galicia, Portugal, Vizcaya y provincia de Guipúzcoa, confiesa haber recibido 3 ducados cada uno del sueldo de tres meses, como marineros.

Despensero, san Juan de Santa Cruz

Lombardero, Francisco de la Sierra

Escribano, Antón de Sevilla

Otros marineros: Pedro de Argumedo, Juan de Suances, Pedro de Nates y Juan de las Peñas (Idem, fol. 384). 
Los dueños de la zabra La Concepción, que estaba en servicio real en el Reino de Andalucía y antes en la armada de la Isla Tercera, zabra con la que habían servido muchas veces al Rey, en especial, en la harmada que juntó Juan Martínez de Recalde por el año de ochenta y dos, y en la condución del trigo que se llevó de la villa de Santander al Reino del Andalucía por horden de don García Girón, corregidor de Palencia y juez de la dicha comisión, y bien ansi en la presente y feliz jornada que se hizo en la Isla de la Tercera, yendo por general el Marqués de Santa Cruz, y en la reductión de la ciudad de Lisboa, en Reino de Portugal, en las quales dichas ocasiones la dicha nuestra zabra a servido y de presente sirve en el dicho Reino del Andalucía, a do está enbargada por llevar bastimentos a Larache, y de lo susodicho se nos deven muchas quantías de mrs., en especial, de las ocasiones de Portugal y del servicio que hizo siendo general el dicho Juan Martínez de Recalde, otorgan poder para cobrar. ${ }^{12}$

Por los poderes para cobrar y los finiquitos librados más tarde sabemos de parte de los intervinientes en esos hechos de armas: Ochoa de Cabra, ${ }^{13}$ Juan del Corro, ${ }^{14}$ Pedro de Herrado ${ }^{15}$ Pedro de Gijón ${ }^{16}$ y los dueños de las naves castreñas implicadas en la conquista de la Isla Tercera.

Los dueños de las naves que habían participado en la Jornada de la Isla Tercera renuevan los poderes dados para cobrar sus derechos de la Hacienda real a favor de Diego de Noja Castillo.

Relación:

- Pedro de Vidania, dueño de la zabra que llevó Martín Pérez de Lastero.

- Bartolo de Palacio.

— Diego Marmolejo de Sevilla, dueño de la pinaza que llevó Juan de Trápaga.

— Domingo de Laredo.

— Martín de Turpín, dueño de la pinaza que llevó Juan de Trocica.

- Pedro de Jimeno.

- Martín de Lastero Aparicio, dueño de las zabras que llevó Ochoa de Acosta.

\footnotetext{
12 1584/03/15. Castro Urdiales (AHPC, prot. 1.696, fol. 145-147).

${ }^{13} 1586 / 08 / 25$. Castro Urdiales. Ochoa de Cabra, vecino de Castro, otorga poder a Mari Sáenz de Carasa, su mujer, y a Juan de Carasa, su cuñado, para cobrar todo el sueldo que me pertenece de la Jornada de la Tercera, que yo gané con una zabra [de] que hera maestre (AHPC, prot. 1.717 (1586), fol. 170).

${ }^{14} 1586 / 08 / 25$. Castro Urdiales. Juan del Corro, vecino de Castro, otorga poder a Catalina de Vitoria, su mujer, para cobrar del sueldo que e serbydo a S.M. en lo de Portugal y la toma de la Tercera y en la presente Jornada que boy en serbycio de S.M. (Ibidem, fol. 171).

${ }_{15}$ 1587/02/20. Castro Urdiales. San Juan de Herrado, vecino de Castro, hermano de Pedro de Herrado, difunto, que sirvió en la Jornada de la Isla Tercera y dixo que el dicho su hermano huvo de haver cantidad de mrs. por su persona, navio y parte marinera que llevó desde esta villa a la dicha Isla Tercera; todos los acreedores locales habían nombrado procurador para ir a cobrar a Lisboa a Diego de Noja Castillo; él, por su parte, nombra a Clara de Herrado, mujer de Pedro Marmolejo de Sevilla, vecina de Castro, con poder para sustituir (AHPC, prot. 1.697 (1587), doc. 20).

${ }_{16}$ 1587/10/29. Castro Urdiales. Pedro de Gijón, vecino del puerto de Santoña, dueño y maestre que fue del patache La Concepción, que sirvió en la Jornada de la Isla Tercera, otorga carta de pago por sí y por sus marineros a Diego de Noja Castillo, procurador en Lisboa, que le había hecho pago de las cantidades adeudadas por la Hacienda real (da cuenta pormenorizada) (Ibidem, doc. 116).
} 
- Antón de Ampuero.

- Diego Saenz de Lastero, parcionero de la pinaza en que fue como maestre Pedro de Carranza difunto.

- Juan de Marrón.

- Diego de Trucíos, dueño de la pinaza de que fue maestre Domingo de Somarriba.

- Juan de Santa Cruz.

- Francisco de Castro Colina.

- san Juan de Herrado, como heredero de Pedro de Herrado difunto.

— Teresa de Avellaneda, viuda de Hernando de Perdón, como tutora y curadora de sus hijos.

- Catalina de Perdón, viuda de Santiago de Avellaneda.

- Catalina de Argumedo, mujer de Sancho de Somarriba, maestre que fue del patache llamado La Concepción, ausente en servicio real.

Todos vecinos de Castro Urdiales, dueños de las 14 pinazas y seis pataches que sirvieron el año 1582 en la Jornada de la Isla Tercera. ${ }^{17}$

Mientras todos estos marinos andaban en sus cuitas de cobrar sus atrasos, la Corona ya había decidido iniciar los preparativos para el asalto a Inglaterra. Para ello era prioritario conseguir la marinería precisa; el monarca encomendó esa labor en el área cántabra a don Ordoño de Zamudio, señor de las casas de Zamudio, Zugasti, Martiarto y Guecho, caballero de la Orden de Alcántara o Santiago, en su calidad de corregidor de las Cuatro Villas de la Costa de la Mar, a don Antonio Hurtado de Mendoza, caballero de Castro Urdiales, y a García de Arce Cabeza de Vaca, capitán general de la provincia de Guipúzcoa y alcaide de Fuenterrabía. Las dilaciones producidas por el mal entendimiento entre Zamudio y Hurtado de Mendoza dieron lugar a unos requerimientos mutuos — que afortunadamente se pusieron por escrito y han llegado hasta nosotros-, en los que ambos pretendían salvar la cara frente al Rey. ${ }^{18}$

Inició el fuego don Ordoño, que a comienzos de abril, estando en Laredo, ordenó al alcaide de Castro Urdiales que requiriese a don Antonio para que, en cumplimiento de las reales órdenes, le enviase a examen los marineros necesarios para equipar las naves de la flota a ellos encomendada, a fin de alistarles y adelantarles sus pagas, teniendo certeza de que acudirían al servicio, sin que fuese óbice el disponer del dinero necesario. Dos días más tarde, el alcaide castreño Antonio de Olarte Otañes notificaba la anterior orden a Hurtado de Mendoza.

Contestó éste de inmediato que, como le era notorio al corregidor, por orden regia él se había venido de Lisboa para las Cuatro Villas y señorío de Vizcaya, armado con una real cédula de comisión (Madrid, 28/12/1586) para prender, castigar y hacer retornar a la capital portuguesa a todos los marineros de su flotilla que habían desertado $^{19}$ en aquella ciudad, en Andalucía y en el Reino de Galicia; tal cédula la había

\footnotetext{
${ }^{17}$ 1587/02/19. Castro Urdiales (Idem, doc. 19).

${ }^{18}$ Entre los meses de abril y mayo de 1587 (AHPC, prot. 1.697 (1587), doc. 53, 54 y 56) (Apéndice I, doc. $1 / \mathrm{a}-1 / \mathrm{c})$.

${ }^{19}$ Utilizo a propio intento el término «desertor» para estos marineros vueltos a su tierra sin licencia, aunque no es correcto; la relación jurídica establecida por estos súbditos con la Corona al alistarse y re-
} 
exhibido ante el corregidor, a pesar de lo cual éste le impedía cumplir con lo ordenado, pues hacía echar bandos y pregones por las calles de esas villas, contradiciendo lo actuado por el comisionado.

El día 14/02/1587 el Rey le había encomendado, como ya lo había hecho por otras anteriores, que procediese a la recogida de marineros huidos a la mayor brevedad posible, al tiempo que ordenaba al corregidor que le favoreciese en todo y no le pusiese impedimento alguno. También esa carta se la mostró don Antonio a Zamudio.

El 3 de marzo le ofició de nuevo el monarca que continuase con lo mandado y realizase nueva leva de marineros, que con ellos volviese a Lisboa con toda diligencia; al corregidor le había ordenado que consiguiese 20.548 reales con los que costear el nuevo alistamiento y pagar los gastos del transporte, en tanto la Corona proveía esos recursos. De nuevo comunicó a Zamudio el contenido de esa carta, haciéndole ver la necesidad de conseguir pronto la mencionada cantidad, pareciéndole al caballero que el corregidor no se había dado mucha prisa en reunirla.

El 9 de marzo el monarca volvió a apremiar a don Antonio: debía tomar cuatro pataches o los navíos (zabras y pataches) que creyera preciso para embarcar a los marineros nuevamente conscriptos y llevarlos sin dilación a Lisboa, surtiéndose de la cantidad que debía obrar en manos del corregidor. Nuevamente puso en conocimiento de éste sus órdenes, haciéndole constar cómo estaba ya concertado con los dueños de los bajeles para que el día 10 de abril pudiera embarcar en ellos 200 marineros, apropiados y alistados ante escribano, con tal de disponer de los recursos prometidos, pero Zamudio dijo que no tenía el dinero en su poder, que parte estaba en el depositario de la villa de Laredo, parte en poder de Hernando de la Riva Herrero, en Santander, y la mayor parte en San Vicente de la Barquera, en obligaciones por cobrar; que había enviado a apurar el cobro primero al Lcdo. Escalante y ahora a Pedro del Casal, sin haber reunido aún el dinero.

En otra carta regia de 23 de marzo, que había recibido el 28 , era conminado a cumplir todo lo encargado, contando con el dinero del corregidor. A la hora de recibirla, la remitió a Laredo a Zamudio, urgiéndole según se le mandaba, que el dinero era preciso para sufragar los cuatro pataches, avituallarlos y pagar a los alistados y que se significase a los alistados que concurriesen armados. Contestó Zamudio que había reclamado el dinero a Santander y San Vicente sin éxito, que, en cuanto al armamento, tenía orden de no permitir que los marineros lo llevasen a sus casas. De nuevo urgió Hurtado de Mendoza al corregidor, pues ya había mucha demora en el cumplimiento de las anteriores órdenes. Pero Zamudio no había querido responderle, por lo que sugería que sería conveniente publicar las órdenes que tenía el corregidor y cómo las incumplía, en perjuicio del servicio real.

cibir sus pagas adelantadas, lo que conllevaba la obligación de prestar el servicio en los navíos embargados, a mi juicio, era más de carácter privado que público, no pudiendo castigarse por la vía penal, sino por la civil, por incumplimiento de contrato, aunque con cierta penalidad (ser puestos en la red, esto es, encarcelados). 
Añadía que haberle requerido para que le remitiese los marineros alistados era una labor imposible, pues no se podía alistarles sin dinero ni pagar a los dueños de los navíos para el transporte, además, la elección de las tripulaciones era asunto de su propia competencia, no de la del corregidor, del cual lo único que se esperaba es que reuniera el dinero a fin de cumplir todo lo demás. Que, si no quisiera darle a él los veinte mil y pico reales, los diese a los dueños de los pataches, que ya se habían obligado a facilitar los 200 marineros para las tripulaciones.

La réplica a la contestación del caballero Hurtado de Mendoza la dio el corregidor Zamudio en Castro Urdiales, el 2 de mayo siguiente, en una exposición un tanto confusa. Tras exponer cómo S.M. le había ordenado auxiliar al capitán general de Guipúzcoa en el embargo de naves y recluta de marinería y demás cosas que García de Arce le cometiese, habiendo llegado para ello el capitán Hernando de Muñoz con dinero, añade que a don Antonio le constaba por carta regia, recibida el primero de mayo, cómo se le había ordenado aprestar 15 pinazas con marineros, pero éstos se inclinaban más, por las ventajas y comodidades que les suponía ir en naves de su tierra, a alistarse en ellas y no en otras, por lo que le requería a que cumpliese su comisión, alistando a los hombres en naves de su comarca.

Hurtado de Mendoza escuchó lo expresado por el corregidor, pidió testimonio y al rato contestó al anterior requerimiento: con su contrastada precisión replicó que al corregidor le era notorio cómo por carta del 3 de marzo se le había ordenado reclutar más marineros para llevarlos a Lisboa, que Zamudio le proveería del dinero necesario, pero no se lo había facilitado. Por cartas de 9 y 23 de marzo se le había reiterado lo mismo, obteniendo del corregidor idéntico resultado, sin tener alistados los 300 marineros y acopiadas las vituallas necesarias para aquellos marineros y para los que había recogido de los que se volvieron, por la falta de dinero. El 14 de abril el Rey le había preguntado si podría obtener en Castro 14 o 15 pinazas tripuladas para llevar a Lisboa a su gente; le contestó que en la villa había 20 pinazas en total, cuyos dueños serían dichosos de llevar a la gente a la capital lusa, pagándoseles como de costumbre.

El 21 de febrero le había escrito el marqués de Santa Cruz diciéndole que, si el Rey le mandase escoger algunos pataches, los eligiera con ciertas características (muy veleros, fuertes, nuevos, gobernables y aptos para hacer frente a corsarios); si S.M. le ordenase elegir algunas pinazas, procurase que fueran equipadas por buenos bogadores, en número de 20 o 22, y que se hiciera de acuerdo como él le tenía ordenado; que todo ello lo hiciese con extraordinaria diligencia. El 11 de abril recibió un nuevo despacho: Santa Cruz le insistía en que proveyera lo de las naves y marineros, que S.M. mandaría el dinero necesario, pero que impidiera que salieran a bogar y que estuvieran prestos para venir a servir al Rey, con quien ganarían mejor salario que con cualquiera. El primero de mayo recibió otra carta de don Álvaro, fechada en 18 de abril, recordándole todo lo que le había ordenado en su carta del 21 de febrero, para que lo cumpliese sin falta. Don Antonio había vuelto a hablar con los dueños de pataches y pinazas, esforzándoles en el servicio real. 
El 27 de abril había escrito al Rey sobre las órdenes recibidas, haciéndole constar las cantidades necesarias para llevarlas a efecto, así para la nueva leva hecha por él mismo, como para los 100 marineros del capitán Juan de la Puebla y para los 200 desertores, apresados gracias a las gestiones del corregidor y sus hombres y del propio don Antonio, para las 12 pinazas y sus tripulantes, de su sueldo y vituallas para un mes.

En cuanto a lo que decía Zamudio de estar en Castro por orden real transmitida por García de Arce, para que embargase naves, levase marinería, etc., hasta la fecha no había tenido noticia de nada de ello, sino que, si el corregidor estaba allí, era para poner a punto entre ambos - Zamudio y Hurtado de Mendoza- los 60 marineros que el corregidor de Vizcaya había pedido para equipar dos pataches. Que, si no fuera por los incumplimientos de Zamudio, él ya estaría en Lisboa cumpliendo órdenes y no enredado en requerimientos. Que el tener a punto naves, hombres y vituallas a tiempo dependía tan sólo de que don Ordoño facilitase el dinero necesario, nada más.

Ahí terminan las disputas conservadas entre corregidor y caballero; sin embargo, pocos días antes el corregidor de las Cuatro Villas había acudido a Castro Urdiales para registrar a los marineros vueltos de Lisboa y otras partes sin licencia. ${ }^{20}$ El 28 de abril hizo público un pregón, en el que exponía que estando para partir los navíos que habían de devolverles a su destino, concurriesen antes de la 8 de la mañana del día siguiente en las casas de la gobernación para tomar nota de sus personas, señales y armas. El pregonero Luis Romero leyó el mandato en la plaza de la villa y demás lugares acostumbrados. El día siguiente el corregidor Zamudio y el escribano Peñavera, en la casa del ayuntamiento, fueron recibiendo a los encartados y anotando sus nombres, navíos a los que estaban adscritos, edad, complexión, tachas físicas y otras características personales, tales como si tenían o no barba, color del pelo, defectos, etc. ${ }^{21}$

En total se reseñaron 71 marineros - descontados los tres ojeteados, que no comparecieron—, ${ }^{22}$ que el día 4 de mayo fueron embarcados en una pinaza rumbo a Por-

\footnotetext{
${ }^{20}$ Apéndice I, doc. 1/d.

${ }^{21}$ Entre todos los detalles reseñados llama la atención las edades tempranas de algunos, los defectos físicos que no impedían el servicio y, sobre todo, la abundancia de marineros pelirrojos, característica que hoy no se conserva en la zona.

${ }^{22}$ Uno de los que no compareció fue Juan Fernández de Portonovo, vecino de Castro, que hubo de ser fiado por su esposa y su suegro:

1591/01/16. Castro Urdiales. Antón de Rueda y su hija, María de Rueda, vecinos de Castro, por cuanto don Luis Fajardo, corregidor de las Cuatro Villas, por virtud de cédula real, procedió en 1589 en Laredo contra los marineros vueltos y quedados del servicio real en la armada para el Reino de Inglaterra, siendo prendido Juan Fernández de Portonovo, yerno de Antón y marido de María, y condenado a 5 años de galeras al remo y otras penas, siendo llevado para ello a las galeras de El Ferrol, donde estaba sirviendo de forzado.

Como el reo era marinero y era de mayor provecho que sirviese de tal, quitándole además de vejaciones y trabajos, había tratado el tema para que sirviese de marinero el tiempo de su condena sin cobrar en nave real, dando fianzas de que lo serviría y no se fugaría, con fiador de 200 ducados. Al no haber encontrado quién lo fiara, suegro y esposa lo hacen, hipotecando a ello sus bienes, que relacionan
} 
tugalete, con don Antonio Hurtado de Mendoza, que pasó lista. En Portugalete serían recibidos por el Lcdo. Duarte de Acuña, corregidor del señorío de Vizcaya, que tenía preparados dos navíos para remitirlos a Lisboa con su superior.

Como decía más arriba, hubo tres autoridades reclutando marinería a un tiempo; el tercero fue García de Arce, capitán general de Guipúzcoa, el cual el 23 de mayo, en San Sebastián, daba poder al capitán Fernando de Muñoz, vecino de dicha villa, para ir a alistar marineros en tierras de Vizcaya y de las Cuatro Villas, ya que en aquella provincia no había suficientes personas capaces de tripular la armada de $5.000 \mathrm{o}$ 6.000 toneladas que el Rey había mandado preparar allí. ${ }^{23}$ Los alistados debían ser útiles para el servicio y prácticos en la navegación, así como abonados, para responder de las cinco pagas (15 ducados) que se les abonarían por adelantado.

El 4 de mayo Muñoz presentó su poder ante el escribano Peñavera y comenzaron el alistamiento, en presencia del corregidor Zamudio, que sólo se extendió a ese día y al siguiente, reclutándose tan sólo a cinco personas, procedentes de San Martín de Ontón (Castro Urdiales) y Guecho, Nuestra Señora de Erandio y Puerto de Asua, en esa misma anteiglesia, padre e hijo, los cuatro últimos en Vizcaya.

A través del listado de los hombres reembarcados para Lisboa podemos saber las naves castreñas que en 1586 habían sido ya desplazadas con marinería local para la Gran Armada; dejando a un lado un marinero embarcado en la Almiranta de Guipúzcoa y otro en el galeón San Cristóbal, las demás parecen ser todas de Castro Urdiales, de acuerdo con los apellidos de sus maestres o armadores. Suponemos que los hombres alistados y el escribano de una villa costera estarían al tanto de los distintos tipos de naves existentes en aquella época, por lo que hemos de dar fe a las denominaciones que utilizan; así, encontramos que hablan de zabras y navíos, zabras y pinazas, navíos

(AHPC, prot. 1.698 (1591), doc. 4). En el día, Antón otorgó carta de obligación en el mismo sentido (gratis) (Ibidem, doc. 5).

Otros que no comparecieron fueron Francisco de Montellano, vecino de Castro, cuyo padre, del mismo nombre, haziendo de deuda ajena cargo propio, se obligó y prestó fianza de entregarle cuando fuese reclamado para prestar servicio como marinero; en la misma situación se encontraban Diego de Santa Olalla, con respecto a su hijo Gonzalo, o Francisco de Prado respecto de Antón de Rasines (AHPC, prot. 1.697 (1587), doc. 65-67). Otros como Pedro de Argoños y Ochoa del Cotillo, vecinos de San Jorge de Santurce, llegaron tarde a embarcarse en Laredo, en los navíos fletados en San Sebastián, cuyo general era Miguel de Oquedo, obligándose o bien a servir en la infantería o a devolver los 200 y 100 reales, recibidos respectivamente por ellos (Ibidem, doc. 109). Más pintoresco es el caso de Juan de Ceballos, maestro yesero de Castro, que ante la marcha en la armada de Toribio Callejo, del mismo oficio, se ofrecía a abastecer de yeso a la villa, mejorando el precio fijado por su competidor embarcado (Idem, doc. 113).

En otros casos, no parece que los marinos desertores se reincorporaran voluntariamente:

1586/10/30. Castro Urdiales. Nuño de la Quintana, vecino de Castro, comparece ante el escribano y expone que Alonso Gómez, vecino de Muros, en Galicia, había traído en su navío, surto en el puerto, siete marineros que decían venir fugidos de la ciudad de Lisboa. Alonso había prestado fianza de llevarlos ante García de Arce, general de la armada, en San Sebastián (AHPC, prot. 1.696, fol. 413).

${ }^{23}$ Apéndice I, doc. 2. 
y pataches, navíos y pinazas indistintamente, lo cual no deja de ser sorprendente; en una ocasión hablan de «nao», pero lo más común es englobar el tipo de nave en el nombre genérico de «navío». ${ }^{24}$

Con la salvedad expuesta, pues, éstas serían las naves en la relación de los reembarcados:

— nao de Juan Pérez de Amurrio

- pinaza de Diego Marmolejo de Sevilla

— pinaza de Domingo de Somarriba

— zabra/navío de Alonso de Lastero

— zabra/pinaza de Francisco Galván

— zabra/pinaza de Martín de Solórzano (perdida entonces)

— zabra/pinaza de Diego de la Gándara

— zabra/pinaza de Juan de Valmaseda

— navío/patache de Pedro Marmolejo de Sevilla

— navío/pinaza de Diego de Carasa

— navío de Juan Gordon

- navío de Francisco de Lastero

- navío de Antón de Carasa

- navío de Sancho de Somarriba

— navío de Juan Galván

— navío de Juan de San Martín Garbijos

— navío de Pedro Garbijos de Puerto

Así pues, se trataba de una nao y 16 naves auxiliares.

De acuerdo con los datos recopilados por Casado Soto en Simancas, en la Gran Armada participaron las siguientes naves auxiliares:

— en la escuadra de Castilla, dos pataches (Nuestra Señora del Socorro y San Antonio de Padua), de destino desconocido.

- en la escuadra de Vizcaya, cuatro pataches (María, San Esteban, Isabela y María, de nuevo), que aportaron, respectivamente, a Santander, La Coruña (dos) y Pasajes.

\footnotetext{
${ }^{24}$ Como exponía más arriba, el tema de la tipología de naves fue una de las preocupaciones de Casado Soto; hablando de las naves usadas en la guerra distingue entre naos, buques auxiliares, galeones agalerados, galeazas y galeones. Dentro de las auxiliares contempla navíos, zabras, chalupas y pinazas. «Los primeros, barcos mancos, se usaban para el cometido de pataches, mientras que los segundos, más ligeros, sutiles y maniobreros, hacían la función de avisos, correos y remolcaciones». Respecto a los navíos, de los que dice que tenían una acepción genérica como nave, solían ser bajeles de porte inferior a la nao; «cuando eran enrolados en armada recibían el nombre de 'pataches', lo que entonces significaba buque auxiliar» (op. cit., pp. 118-153; las citas concretas en pp. 131 y 134).

En efecto, en el listado de naves usadas en Santander en el siglo XVI describe la nao, el galeón, el navío, la zabra, la pinaza, la chalupa y el batel (Santander, una villa marinera en el siglo XVI, Santander, 1990, pp. 44-48).
} 
— en la escuadra de Guipúzcoa, dos pataches (San Bernabé y La Asunción) y dos pinazas (Magdalena y Nuestra Señora de Guadalupe), todas con destino en Pasajes, salvo la primera, que aportó en San Sebastián.

- en la escuadra de Andalucía, un patache (Espíritu Santo), que retornó a Santander.

- en la escuadra de pataches y zabras, además de dos urcas y una nao (Nuestra Señora del Pilar de Zaragoza), sirvieron 11 pataches (Santo Crucifijo de Burgos, La Concepción de Lastero, La Concepción de Carasa, Nuestra Señora de Fresneda, La Concepción de Castro, Nuestra Señora de Guadalupe, Nuestra Señora de Begoña, La Concepción de Capitillo, Nuestra Señora de Gracia, Nuestra Señora del Puerto y San Jerónimo) y siete zabras (San Juan de Carasa, La Trinidad, Santa Catalina, La Concepción de Valmaseda, Nuestra Señora de Castro, San Andrés y La Asunción) ${ }^{25}$ Des-

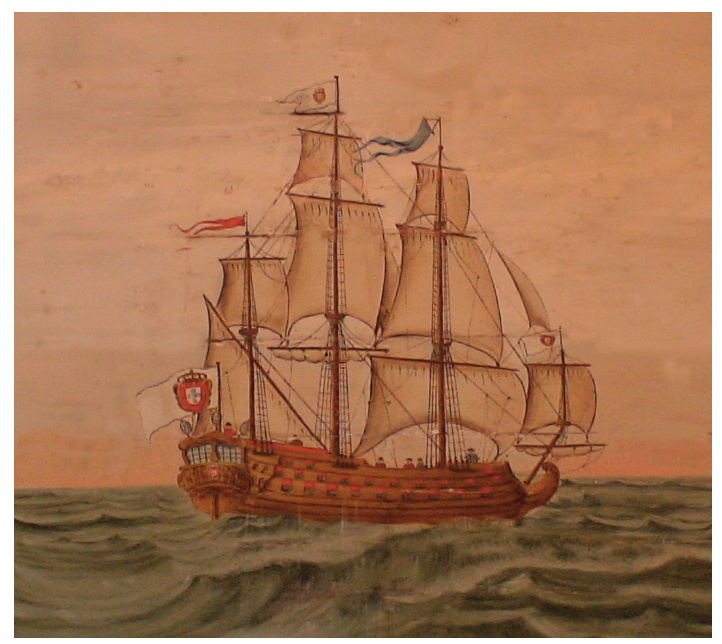

Buque portugués

conocía Casado Soto el destino que sufrieron tanto La Concepción de Lastero como Nuestra Señora de Begoña, dando por perdida tan sólo Nuestra Señora de Castro; las 15 naves restantes tornaron a tierra española o controlada por españoles: dos fueron a Dunquerque (San Juan de Carasa y Santa Catalina), una a San Sebastián (Nuestra Señora de Gracia), otra a Laredo (Santo Crucifijo), cuatro a Castro Urdiales (La Concepción de Carasa, La Concepción de Castro, San Jerónimo y La Concepción de Valmaseda) y las otras siete a Santander.

Según el mismo autor, no hubo naves auxiliares en la escuadra de Portugal, sin embargo Martin y Parker reseñan dos zabras (Augusta y Julia), que para Casado Soto eran galeoncetes portugueses. Ambos grupos de autores coinciden en los dos pataches

${ }^{25}$ Los barcos españoles del siglo XVI ..., pp. 382-384. También Fernández Duro, II, pp. 64-65. 
que iban en la escuadra de Castilla, los cuatro pataches de la escuadra de Vizcaya, los dos pataches y dos pinazas de la escuadra de Guipúzcoa y el patache Espíritu Sancho de la escuadra de Andalucía - a cargo de la misma don Pedro de Valdés ${ }^{26}$ - No obstante, en la escuadra de más interés para nosotros, la de pataches y zabras, Martin y Parker, tras exponer que la comandaba Agustín de Ojeda desde la nao Nuestra Señora del Pilar de Zaragoza, citan las dos urcas inglesas de la Corona, y 18 o 19 pataches y zabras más, así como 10 carabelas y 10 falúas. ${ }^{27}$

Lástima que los autores anglosajones no se tomasen la molestia de reseñar estas humildes naves, que, a pesar de ello, desarrollaron su cometido tan bien como el navío mejor artillado de la Armada. En cambio, Casado Soto nos añade algunas noticias de interés sobre esta flotilla: como ya sabemos, fueron el corregidor de las Cuatro Villas y don Antonio Hurtado de Mendoza quienes reclutaron los 8 pataches y 8 zabras que se concentraron en Castro Urdiales para, acompañados de la escuadra de Guipúzcoa, levantada por Juan Martínez de Recalde, marchar a Lisboa en el verano de 1586 — partieron de Castro el 24/08/1586—; durante los meses siguientes estos bajeles prestaron servicios diversos y como correos con Andalucía y el Cantábrico - pasando penalidades sin cuento por falta de pago de sus salarios, según Echavarría, lo que explicaría las numerosas deserciones-, hasta que a inicios de 1588 , salieron, como siempre, comandados por don Antonio Hurtado desde la nao Nuestra Señora del Pilar - este caballero fallecería en La Coruña en el verano de 1588, siendo sustituido en el mando por Ojeda-, para la Jornada de Inglaterra. En la última reorganización llevada a cabo por Bazán, en octubre de 1587, aparecían ya la nao, las dos urcas, 10 pataches y ocho zabras, a las que en abril se sumó el patache grueso Santo Crucifijo de Burgos, de tonelaje similar a las urcas; a cambio el Espíritu Santo ${ }^{28}$ pasó a la escuadra de Andalucía. Ya en La Coruña, el patache San Francisco sería sustituido por Nuestra Señora de Fresneda y La Concepción de Castro, en tanto que La Concepción de Valmaseda era enviada con correo para Flandes. Con esos efectivos, incorporados a la escuadra de Andalucía, salió esta flotilla, «lo que —en palabras de

\footnotetext{
${ }^{26}$ Valdés fue apresado por Drake, que le agasajó y mantuvo en la Corte inglesa hasta ser rescatado en 1593 contra la entrega de un prisionero y 6.000 ducados (Martin y Parker, pp. 272-275, 347 y 391-392). Ha estudiado los avatares seguidos por Valdés y los tripulantes de su nave Paula Martin (Spanish Armada prisoners. The story of the N.S. del Rosario and her crew, and other prisoners in England, 1587-1597, Exeter, 1988), obra citada por los anteriores autores, que no he tenido ocasión de consultar.

Don Pedro era caballero de la Orden de Santiago y comendador de Oreja, razón por la que cabe encontrar información sobre el mismo en el archivo del Consejo de Órdenes; he localizado un proceso de 1609 , en franco mal estado, en el que los corsarios españoles que habían apresado la nave del general William Winter, embajador de la Reina Isabel ante el duque de Bearn, le reclamaban el rescate del mismo; véase el certificado de estos hechos recogido en el Apéndice II.

Véase, también, la semblanza del personaje hecha por Fernández Duro (I, pp. 167-170).

${ }^{27}$ Martin y Parker, op. cit., pp. 449-452.

${ }^{28}$ Este patache era propiedad de Martín de Cuartas, vecino de Castro, y, al menos, dos años después llevaba por maestre a su propietario (AHPC, prot. 1.697 (1590), doc. 52).
} 
Casado Soto- constituía una novedad, ya que hasta entonces estos barcos sutiles únicamente participaban en las escuadras y armadas como auxiliares de los grandes, pero nunca como unidad orgánica, aunque fuera de apoyo». ${ }^{29}$

A través de las 'hojas de servicios' prestados por los marineros cántabros en estas sutiles naves podemos reconstruir su participación en la Gran Armada, así como su destino final. Hay que tener en cuenta que la falta de precisión a la hora de definir los tipos de barcos y el hecho de que éstos unas veces eran denominados con su nombre de bautismo y otras con el del maestre o del propietario no facilitan siempre la localización de cada uno de ellos.

Casos excepcionales, en cuanto al encuadramiento inicial de los marineros cántabros, que preferían navegar en los barcos de su comarca, son el de Antón de Gijón, vecino de Castro - que sirvió en la Santa Ana, Almiranta de la escuadra de Vizcaya, a cargo de Juan Martínez de Recalde, ${ }^{30}$ donde participó en todos los avatares de la lucha hasta su vuelta a España, luego pasó a otros navíos- ${ }^{31}$ y el de Martín Ruiz de Hozpín, vecino de Castro y morador en Santullán — que fue como carpintero en el galeón San Cristóbal (no se especifica si en el de la escuadra de Portugal o en el de la formación de Castilla) hasta ser licenciado en 03/11/1590-.32

Comenzando por la nao Nuestra Señora del Pilar de Zaragoza, tan sólo sabemos que sirvió en la misma como artillero Pascual Beltrán, con seguridad vecino de Castro Urdiales; cobró de los testamentarios de Felipe II sus honorarios, 24.000 mrs., una viuda, segunda esposa del segundo marido de su viuda. ${ }^{33}$ Por Casado Soto sabemos

${ }^{29}$ Casado Soto, op. cit., pp. 220-221. No todas las naves disponibles fueron movilizadas, así, por ejemplo, las zabras San Pedro (dueño Martín del Río, maestre Colás Gómez) (AHPC, prot. 1.697 (1587), doc. 57 y 62) y Santa Ana (maestre Juan de Manzanas) (Ibidem, doc. 64), fueron arrestadas para el servicio real, pero finalmente no participaron en la Jornada de Inglaterra.

${ }_{30}$ 1591/01/16. Castro Urdiales. Juan de Macatene, regidor perpetuo de Laredo, otorga carta de pago a Martín del Río, vecino de Castro, curador de los hijos del difunto Martín de Cereceda, vecino de Castro, por 84.000 mrs. que los bienes de Juan Martínez de Recalde el viejo le debían, por una carta de pago que contra ellos tenía. Macatene había ejecutado los bienes de Juan Martínez de Recalde el mozo, Almirante general que fue de la armada de la guerra de Inglaterra (AHPC, prot. 1.698 (1591), doc. 11).

${ }^{31} 1594 / 07 / 14$. Castro Urdiales. Antón de Gijón, vecino de Castro, alistado en mayo de 1586, sirvió en una de las zabras castreñas por marinero y en la Almiranta de Juan Martínez de Recalde, yendo y volviendo de la Jornada de Inglaterra; también en la nave de Agustín de Landacho con el general Bertendona y en los galeones San Bernabé y San Felipe y de contramaestre en una zabra de Martín de Santander, vecino de Laredo (AHPC, prot. 1.699, poderes, doc. 42tris).

${ }^{32}$ 1607/05/02. Castro Urdiales. Martín Ruiz de Hozpín, vecino de Santullán, entre otros, se había alistado en 1588 para la Jornada de Inglaterra, sirviendo de carpintero desde 02/08/1589 hasta 03/11/1590; también sirvió de carpintero en el galeón Santo Tomás de 11/06/1591 hasta último día del mismo; y en el galeón y nao San Francisco de la Presa, desde 11/07/1591 hasta 01/09/1592, otorga poder para cobrar (AHPC, prot. 1.704 (1607), fol. 343-344).

1609/05/09. Castro Urdiales. Martín Ruiz de Hozpín, vecino de Castro y morador en Santullán, otorga poder a Miranda, para cobrar sus sueldos del servicio prestado durante la Jornada de Inglaterra, yendo como carpintero en el galeón San Cristóbal, hasta 03/11/1590 (AHPC, prot. 1.705, fol. 108-109). ${ }^{33}$ 1609/09/14. Castro Urdiales. María de la Garreada, viuda de Juan de Helguera, otorga poder a Martín de Miranda, vecino de Castro y viandante en Madrid, para cobrar de los testamentarios de Felipe II, 
que esta nave retornó a Laredo tras la Jornada de Inglaterra. Beltrán siguió enrolado en las armadas reales, muriendo de peste en 1598 en La Coruña, cuando ostentaba el cargo de contramaestre del patache La Concepción; testó ante un compañero. ${ }^{34}$

En relación con los once pataches, al parecer sólo sirvieron marineros castreños en los tres denominados La Concepción (de Lastero, de Carasa y de Castro), ${ }^{35}$ en Nuestra Señora de Begoña y San Jerónimo.

—patache San Jerónimo (dueño y maestre Pedro Marmolejo de Sevilla).

En éste prestaron servicios cuatro sujetos: san Juan de Rueda, Pedro de Soba, Toribio Díaz y Tiso de Escobedo. Rueda era uno de los desertores, tenía 25 años en 1587 , era de pequeña estatura, pero robusto y de buen gesto. Vecino de Castro, se había alistado en mayo de 1586 como escribano, fue a Lisboa, Puerto de Santa María, Lisboa, La Coruña, Jornada de Inglaterra, vuelta de Noruega y retornó en conserva de la Capitana hasta Santander, de donde después partió en el dicho pataje con el Espital real al puerto del Ferrol; ${ }^{36}$ luego fue a Lisboa y vuelta a El Ferrol, donde licenciaron el patache. ${ }^{37}$

según nómina de la cédula dada en Madrid, 16/02/1609, mandando pagar 24.990 mrs. a Pascual Beltrán, que sirvió de artillero en la nao Nuestra Señora del Pilar de Zaragoza. Beltrán dejó como heredera universal a su esposa, María del Pin, que dejó una niña, muerta en edad pupilar sin testar; le heredó, pues, Helguera, segundo marido de María del Pin y luego marido de María la Garreada (AHPC, prot. 1.705, fol. 198-199).

${ }^{34}$ 1598/12/21 a 23. La Coruña. Gaspar de Avero, vecino de Castro, presenta testamento ajeno y la justicia ordena realizar investigación: Juan Bernal, vecino de Viana, dijo conocer al testador, Pascual Beltrán, que 4 meses atrás llegó al puerto de La Coruña en servicio real, como contramaestre del patache La Concepción; de pronto se sintió mal e hizo testamento ante su compañero Antonio de Castro Colina, vecino de Castro. Fueron testigos, Pascual, Antonio y Juan Ruiz de Lara, y, echo esto, por mandado de la justicia de la ciudad de La Coruña fue llevado en un carro al Ospital de Labañón, adonde estavan otras muchas personas que estavan tocados y heridos del dicho mal de peste, y allí mismo murió. Juan Ruiz de Lara, vecino de Marquina, añade que Pascual era vizcaíno. Antonio de Castro Colina, vecino de Castro, dice que no se alló escrivano al dicho tiempo que le quisiere azer por causa de la dicha enfermedad. El corregidor tiene por corroborado el testamento.

Texto del testamento (1598/06/17. La Coruña): Pascual de Beltrán, vecino de Castro, era contramaestre del navío La Concepción; su heredera, su mujer Marín de Pin (Ibidem, fol. 187-190).

${ }^{35}$ El hecho de que cuatro de las 18 naves aquí consideradas fuesen bateadas con la advocación de «La Concepción» pone a las claras la gran creencia en la inmaculada concepción de la Virgen tenía de los españoles de entoces, mucho antes de que fuese declarado el suyo día de fiesta oficial en España y sus colonias (1644) o de que el Papa Pío IX lo definiese como dogma de la Iglesia Católica (1854).

${ }^{36}$ Uno de los participantes en la Jornada de Inglaterra, que falleció en Santander a los 24 años, a la vuelta del grueso de la flota, fue don Diego Fernández de Córdoba, vecino de Montemayor, pariente cercano, aunque bastardo, del conde de Alcaudete; o, al menos, sabemos que testó en aquella ciudad en 18/10/1588 —ordenó ser enterrado en la parroquia de su pueblo, bajo la parte de dicho conde-, siendo sus testigos, Pedro de Sámano, vecino de Santander, don Alonso de Zárate, vecino de Portugalete, Juan López Herrezuelo, vecino de La Membrilla del Tocón (Campo de Montiel), Juan Alonso, vecino de Caller (Cerdeña), Juan Bautista de Torres, vecino de Torres (Zamora), Francisco Méndez y Diego de Trujillo, ambos vecinos de Málaga (Archivo Histórico Nacional, Órdenes Militares, Archivo Histórico de Toledo, expte. 15.254; proceso entre los Fernández de Córdoba por la propiedad de un molino). 
Pedro de Soba, vecino del Valle de Sámano, también se había alistado en 1586, como marinero-carpintero del San Jerónimo, donde hizo el mencionado trayecto, siendo despedido en Santander; luego se pasó con la misma plaza al galeón Santiago (maestre Francisco de la Sierra), uno de los que se fabricaron en la villa de Santander, con el que fue al puerto de El Ferrol y a Lisboa; más tarde fue en el patache de Domigo de Laredo, vecino de Castro, a la Isla Tercera, donde falleció de enfermedad. ${ }^{38}$

Toribio Díaz, vecino de Castro, fue marinero en ese mismo patache y artillero en otro (Nuestra Señora del Pilar, de Pedro Garbijos), durante la Jornada de Inglaterra. ${ }^{39}$

Tiso de Escobedo, vecino de Mioño, otros de los desertores reembarcados en 1587, tenía entonces 21 años, era desbarbado, de rostro pecoso y seco. Se había alistado en la nave de Marmolejo en mayo de 1586, tuvo un azaroso servicio antes, durante y después de la batalla de Inglaterra, falleciendo ahogado..$^{40}$

- patache Nuestra Señora de Begoña (propietario Juan de Somarriba, vecino de Portugalete).

Aunque sólo conocemos la participación en dicha nave de una persona, Miguel de Basániz, vecino de Castro, su hoja de servicios nos permite conocer con detalle sus actividades militares, que compartió con su convecino Rodrigo de Pin, embarcado en la zabra La Asunción (de Pedro del Río), al menos hasta su retorno a Santander: fueron ambos a Lisboa,

adonde estava la Armada Real, de que hera general el Marqués de Santa Cruz, y de alli fueron en buelta de la Armada de Yndias, y bolvieron a la dicha ciudad de Lisboa,

Fernández Duro, en la relación de entretenidos que iban en la Armada con criados, cita dos personajes de ese nombre, ambos con título de 'don', uno de ellos alférez (II, pp. 71 y 73).

${ }^{37}$ 1594/07/04. Castro Urdiales. San Juan de Rueda, vecino de Castro, alistado en mayo de 1586 por escribano del patache San Jerónimo, dueño Pedro Marmolejo de Sevilla, vecino de Castro (AHPC, prot. 1.699 , poderes, doc. 43$)$.

1596/07/22. Castro Urdiales. Revoca poder a Juan de Marecheaga y lo otorga a Gaspar de Otañes (AHPC, prot. 1.700 (1596), doc. 95). Así pues, no volvió a Castro, como dice Casado Soto, sino a Santander.

${ }_{38}$ 1594/03/20. Castro Urdiales. Francisca de Hoz, viuda de Pedro de Soba, vecina del Valle de Sámano, otorga poder para cobrar a Marecheaga (AHPC, prot. 1.699, poderes, doc. 7).

${ }_{39}$ 1609/04/27. Castro Urdiales. Elvira de Quejo, viuda de Toribio Díaz, vecina de Castro, otorga poder a Miranda (AHPC, prot. 1.705, fol. 93-94). Es probable que el servicio de artillero lo prestase luego de la vuelta de dicha Jornada.

${ }^{40}$ 1594/03/21. Castro Urdiales. María de Pontejo, viuda de Tiso de Escobedo, vecina de Mioño, que se había asentado de marinero en mayo de 1586 en el patache San Jerónimo, dueño y maestre Pedro Marmolejo de Sevilla, yendo a Lisboa, desde donde fue por bastimentos a Andalucía; allí le pasaron a una pinaza que andaba de aviso (capitán y maestre Juan de Hornoas, vecino de Castro), donde asentó plaza de despensero, sirviendo en ella mucho tiempo.

En el patache San Jerónimo había hecho la Jornada de Inglaterra, etc. hasta volver a España; luego marchó a El Ferrol, Isla de Tercera, con la demás armada en busca del henemigo y, andando con el dicho Juan de Hornoas, al tienpo que el general Bertendona tomó la Almiranta ynglesa, le sacaron de la dicha pinaça y le metieron en la dicha nave, adonde se ahogó con la demás gente (AHPC, prot. 1.699, poderes, doc. 8). 
adonde murió el Marqués de Santa Cruz, y bino por general el Duque de Medina Sidonia, y en conserva de toda la Armada benieron a La Coruña y della partieron la Jornada de Ynglaterra y dieron buelta en la Noruega y arribaron a Yrlanda, al puerto de Almerique, y estuvieron en conserva de la nao del capitán Orista, que se quemó en el dicho puerto, ${ }^{41} y$ de allí recojieron la gente y venieron con ella al puerto de Santander, adonde desembarcaron la ynfantería que trayan y la artillería de S.M., y el dicho Rodrigo de Pin se vino a la dicha villa de Castro y a su casa y el dicho Miguel de Basániz fue a la armada de don Alonso de Vaçán, que salió de la dicha villa de Santander a la dicha ciudad de Lisboa y de alli bolvieron al Ferrol, y con licencia del dicho general vino en la nave San Francisco al puerto de Pasax; y en la armada del dicho don Alonso de Baçán sirvió plaça de artillero en el galeón Santiago de la Corona de Castilla. ${ }^{42}$

- patache La Concepción de Lastero (dueños Francisco de Lastero Valverde y Bartolo de San Juan, maestre Sancho de Somarriba).

El resumen de sus actividades durante la Jornada nos lo ofrece uno de los parcioneros, que en 1590 daba poder a García de las Muñecas para reclamar el reembolso del valor de su nave ante el Consejo de Guerra; aunque el barco no volvió a Castro Urdiales, sí lo hicieron sus marineros después de un azaroso viaje. Así lo relata el propio Lastero: ${ }^{43}$

en 1586 los hombres del Rey le habían tomado su nave La Concepción para la empresa de Inglaterra, llevando por maestre a Sancho de Somarriba: partieron del puerto de Castro con las demás de la villa, llevadas por don Antonio Hurtado de Mendoza, para Lisboa, y sirvieron en las ocasiones que les mandó el Marqués de Santa Cruz.

Luego fue a Inglaterra y se halló a el canal y en todo lo que allí pasó, y siguió la Capitana, y yendo por el mar de Noruega, le mandaron seguir a una nave, que apresaron, luego la suya hizo aguas, lo que se comunicó al general, que mandó sacar las armas y municiones del Rey y pasarse al navío capturado, en el que volvieron a España; don Juan de Cárdenas, del Consejo de Guerra, que estaba en Santander, ordenó dar el navío a los dueños, sacando la madera para el apresto de la nueva armada; con lo que su nave había quedado desamparada en el mar de Noruega, razón por la que había quedado muy dañado en su hacienda; además, se le debían muchos sueldos.

Se comprende que Casado Soto no supiera el destino de este navío, perdido en el Mar del Norte, mientras que su tripulación abordaba una nave neutral —escocesa一,

${ }^{41}$ Debe de referirse al navío ragusino La Anunciada, hundido en la desembocadura del Shannon, no lejos de Limerick, adonde había llegado acompañado de cinco pinazas (Martin y Parker, pp. 369-370; mapa de naufragios en p. 382). También La Concepción de Lastero participó en este rescate.

${ }^{42}$ 1594/03/24. Castro Urdiales. Rodrigo de Pin y Miguel de Basániz, vecinos de Castro, alistados en los barcos de don Antonio Hurtado de Mendoza en mayo de 1586, otorgan poder a Marecheaga (Ibidem, poderes, doc. 18).

1596/04/08. Aceca. Felipe II ordena pagar a Miguel de Basániz su sueldo del tiempo que sirvió en Bretaña en los filibotes de cargo del capitán Pedro Zubiaur.

Fe de los libros de la Armada de Inglaterra de 1587: Basániz sirvió de marinero y artillero en el patache Nuestra Señora de Begoña y en el galeón Santiago y San Juan Colorado, desde 22/06/1587 a 27/05/1590, en que pasó al filibote La Irlandesa, hasta 19/08/1590. Se le había pagado el sueldo completo, salvo 60 reales (traslado sacado en Madrid, 27/04/1596) (AHPC, prot. 1.700 (1596), doc. 117). ${ }^{43}$ 1590/03/20. Castro Urdiales (AHPC, prot. 1.697 (1590), doc. 29). 
cargada de madera, con la que consigueron retornar sanos y salvos a España, pues la suya quedó malparada del combate. Antes de ser licenciados, anduvieron buscando mantenimientos para los retornados de la Jornada desde su base en Santander.

Conocemos varios marineros que formaron parte de sus efectivos: san Juan de Cuartas, vecino de Castro, había embarcado en mayo de 1586 como artillero, en compañía de su hijo, Lope de Cuartas, alistado como grumete. ${ }^{44}$ Juan de Miñano, también vecino de Castro. ${ }^{45}$ Los marineros Diego de San Juan y Pedro del Río, vecinos de San Vicente de la Barquera. ${ }^{46}$ Juan de Baeza, vecino del Valle de Otañes, sirvió en Lisboa en esta nave hasta que se volvió a su casa con licencia; hizo la Jornada de Inglaterra en la zabra de san Juan de Carasa. Francisco de Hozpín, vecino de Castro, fue por escribano de esta nave. ${ }^{47}$ Antón de Manzanal, también vecino, se enroló como grumete. ${ }^{48}$ Diego de la Pedrueca, el mayor en días, vecino del Valle de Otañes, mari-

${ }^{44}$ 1594/07/04. Castro Urdiales. San Juan de Cuartas otorga poder a Marecheaga; fueron a Lisboa, salieron a la Isla Tercera para proteger a la flota de Indias, hicieron la Jornada de Inglaterra, Noruega y vuelta en conserva de la Capitana, y en Santander anduvo por vituallas para la armada hasta que licenciaron el navío (AHPC, prot. 1.699, poderes, doc. 41).

1609/03/31. Castro Urdiales. San Juan de Cuartas, artillero del patache La Concepción desde 04/05/1586 a 03/08/1589, otorga poder a Miranda (AHPC, prot. 1.705, fol. 7-8).

1609/12/06. Castro Urdiales. Martín de Miranda, como principal, y Marisa de Cestona, viuda de Francisco de Cestona, como fiadora, se obligan a pagar a san Juan de Cuartas, vecino de Castro, 26.450 mrs. del resto de la cobranza en la Corte de sus servicios en la Jornada de Inglaterra, menos el tercio que competía a Miranda como procurador y otros derechos (Ibidem, fol. 259).

${ }^{45}$ 1594/07/02. Castro Urdiales. Juan de Miñano, vecino de Castro, alistado en mayo de 1586 en el navío La Concepción (dueños Francisco de Lastero y Bartolo de San Juan), fue a Lisboa, Isla Tercera, en protección de la flota de Indias, Jornada de Inglaterra y vuelta en conserva de la Capitana, que llegaron a esta dicha villa de Castro y dende a la dicha villa de Santander, aduciendo vituallas para la armada hasta que licenciaron el patache (AHPC, prot. 1.699, poderes, doc. 42).

1596/05/16. Castro Urdiales. Juan de Miñano, vecino de Castro, otorga otro finiquito a Marecheaga, que le había cobrado por el mismo concepto $27.000 \mathrm{mrs}$. (AHPC, prot. 1.700 (1596), doc. 56).

${ }^{46} 1594 / 08 / 06$. Castro Urdiales. Diego de San Juan y Pedro del Río, vecinos de San Vicente de la Barquera, alistados como marineros en el patache La Concepción, maestre Francisco de Lastero Jimeno, vecino de Castro, en mayo de 1586. Fueron a Lisboa, Isla Tercera, al encuentro con la flota de Indias, Lisboa, Jornada de Inglaterra, vuelta de Noruega, y entraron en Yrlanda a guardar la nave del capitán Olista, y traxeron la gente que en ella había, por se haver perdido alli la dicha nave, y venieron a la dicha villa de Castro, y por mandado de don Juan de Cardona fueron a la villa de Santander y conduxeron bastimentos para la armada real hasta que los licenciaron (AHPC, prot. 1.699, poderes, doc. 48). ${ }^{47}$ 1594/05/13. Castro Urdiales. Francisco de Hozpín, vecino de Castro, alistado por escribano en la pinaza Nuestra Señora de la Concepción, a cargo de Sancho de Somarriba, vecino de Castro, fue a la Jornada de Inglaterra y en la vuelta de Noruega tomaron una nave escocesa cargada de madera, dexando alli la zabra por yr maltractada y de sin provecho, y truxeron el dicho navio a la villa de Santander. También fue como piloto en la zabra de Domingo de Somarriba a El Ferrol, Lisboa e Isla Tercera (AHPC, prot. 1.699, poderes, doc. 38).

${ }_{48}$ 1594/05/02. Castro Urdiales. Antona de Vidania, viuda de Juan de Manzanal, vecina de Castro, como heredera de su hijo, Antón de Manzanal, difunto, alistado en mayo de 1586 como grumete en la zabra de que era maestre Sancho de Somarriba, yendo a la Jornada de Inglaterra, tomas de lenguas y otras ocasiones; luego embarcó en el galeón San Cristóbal, de la escuadra de Sevilla, y en la zabra cuyo maes- 
nero. ${ }^{49}$ Finalmente, sirvió en este patache Sancho de Hoz de la Cuadra, vecino de Castro, cuya hoja se servicios es algo más detallada de lo habitual, ${ }^{50}$ algo que ocurre también en el caso de Santiago de Mena ${ }^{51}$ o en el de Pedro de Somolusa, vecino de Castro. $^{52}$

\section{- patache La Concepción de Carasa (maestre Antón de Carasa).}

De los marineros de esta nave nos ha llegado poca información, resultando dudosa la adscripción a la misma de Martín de Noja y su hijo Tomás, fallecidos en el Mar del Norte; ${ }^{53}$ es posible que fueran en La Concepción de Lastero y perecieran en el

tre era Juan de Carasa, como marinero, en donde le mataron los yngleses (AHPC, prot. 1.699, poderes, doc. 36).

${ }^{49}$ 1594/03/31. Castro Urdiales. Juan de la Pedrueca, Pedro de Laguno, María Ortiz de la Pedrueca, Águeda de la Pedrueca y María de las Herrerías, mujer de Diego de la Pedrueca, vecinos del Valle de Otañes, hijos de Diego de la Pedrueca, el mayor en días, alistado en 1586 como marinero en una zabra, maestre Sancho de Somarriba, fueron a Lisboa, Puerto de Santa María, Jornada de Inglaterra y anduvo conduciendo bastimentos, y murió en el dicho servicio en el Puerto de Santa María (AHPC, prot. 1.699, poderes, doc. 20).

${ }_{50}$ 1594/04/02. Castro Urdiales. Sancho de Hoz de la Cuadra, vecino de Castro, alistado en mayo de 1586 como despensero en la nave La Concepción (maestre Sancho de Somarriba), llevó un criado por paje (Juan de Mollinedo); estuvieron en el Puerto de Santa María quando fue sobre él el henemigo, llevando por cavo a Estevan Ochoa; hicieron la Jornada de Inglaterra y Noruega, donde se les afondó su çabra, haviendo seguido un navio escocés, que le tomaron y se embarcaron en él y venieron a la villa de Santander, en compañia de la Capitana; luego embarcaron en la nave San Cristóbal, de S.M., sirviendo en ella hasta que los pasaron a la zabra Santa Engracia (capitán Juan de Escalante, vecino de Laredo), donde Sancho sirvió de artillero, habiendo actuado en todas las ocasiones con mucha fidelidad (AHPC, prot. 1.699, poderes, doc. 27).

${ }^{51}$ 1594/04/05. Castro Urdiales. Catalina Gómez, viuda de Santiago de Mena, y el hermano de éste, Juan de Mena; Santiago se había alistado como marinero de la zabra de que era maestre Sancho de Somarriba, vecino de Castro, en mayo de 1586, yendo a Lisboa, Puerto de Santa María, al tiempo que fue dañada, Lisboa, La Coruña, Jornada de Inglaterra y, pasando por la Noruega, siguieron una bela y con la refriega el dicho navio quedó tan mal parado que se yba al fondo, y rindieron al contrario y le tomaron y se envarcaron en ella y venieron con la demás armada a la villa de Santander.

Bazán le embarcó en la Capitana de la escuadra de Sevilla y fue a la Isla Tercera, volviendo a El Ferrol: luego fue embarcado para ir de aviso a la costa inglesa con el capitán Escalante; despedido, le volvieron a embarcar en el San Francisco, donde sirvió en las ocasiones que se le ofrecieron (AHPC, prot. 1.699, poderes, doc. 29).

52 1594/04/05. Castro Urdiales. Pedro de Somolusa, vecino de Castro, alistado en mayo de 1586 en la zabra de que era maestre Sancho de Somarriba, ...; ya de vuelta en Santander, embarcó en el galeón San Cristóbal, donde sirvió hasta que Álvaro Flores le pasó a una galeota camino de las Indias y, vuelto, el general Bertendona le pasó a la Capitana como lombardero, donde fue a la costa de Francia (AHPC, prot. 1.699 , poderes, doc. 30 ).

53 1596/07/22. Castro Urdiales. Catalina de Musques, viuda de Martín de Noja y madre de Tomás de Noja, revoca el poder dado a Marecheaga. Marido e hijo fueron en La Concepción como contramaestre y marinero, falleciendo en el mar de Noruega (AHPC, prot. 1.700 (1596), doc. 91).

1609/09/14. Castro Urdiales. Inés de Musques, vecina de Castro, otorga poder a Miranda para cobrar de don Pedro Mesía de Tovar, caballero de Santiago, del Consejo de Hacienda y contador mayor de dicho Consejo, en su calidad de pagador de los descargos de Felipe II, 18.071,5 mrs. (por cédula, dada 
abordaje de la nave escocesa. Tampoco es segura la presencia de Francisco de Quintana, vecino de San Martín de Ontón, en esta nave, como alguacil del agua. ${ }^{54}$ Sólo podemos mencionar con seguridad la presencia como marinero de Domingo de $\mathrm{Cu}$ dillero, vecino de Castro, ${ }^{55}$ así como la de Domingo Suárez, marinero en este patache, en el San Jerónimo y en la zabra San Juan Bautista de la Esperanza, entre 02/05/1586 y 15/11/1590. ${ }^{56}$ También parece segura la adscripción a este patache de Francisco de Oconos u Ozoños, vecino de Santullán. ${ }^{57}$

Del patache La Concepción de Castro carecemos de datos por completo; tan sólo suponemos que naufragó en la costa irlandesa, cerca de Smerwick. ${ }^{58}$

en Madrid, 16/02/1609), a pagar a Martín de Noja, difunto vecino que fue de Castro, del servicio de marinero en la Jornada de Inglaterra, en 1588. Dinero perteneciente a su hija María de Noja y a su viuda, Inés de Musques (AHPC, prot. 1.705, fol. 200).

Martín era mercader y cargador en el patache La Asunción (maestre Pedro del Río) en 1587 (AHPC, prot. 1.697 (1587), doc. 55).

${ }_{54}$ 1609/07/18. Castro Urdiales. Francisco de Quintana, vecino de San Martín de Ontón, otorga poder a Miranda: que sirbió de alguacil del agua en la hazabra nonbrada La Concepción de Nuestra Señora y en la nave nonbrada San Juan Bautista, de las que fueron en la Harmada que el año de quinientos y ochenta y ocho fue a Yngalaterra; para cobrar $40.079 \mathrm{mrs}$. librados por cédula real (Segovia, 04/07/1609) sobre bienes de la real almoneda, en la nómina de 19 personas que sirvieron en esa Jornada de Yngalaterra y otras partes, de marinero y de otras plaças y jornadas (AHPC, prot. 1.705, fol. 191192).

${ }^{55}$ 1596/07/22. Castro Urdiales. Domingo de Cudillero, vecino de Castro, marinero en la nave La Concepción (maestre Antón de Carasa), revoca el poder dado a Marecheaga y lo otorga, en su lugar, a Gaspar de Otañes. Se especifica que Domingo había vuelto en conserva de la Capitana, tras la Jornada de Inglaterra, fue con el Hospital real a El Ferrol y sirvió en Francia a Zibiaur (AHPC, prot. 1.700 (1596), doc. 89).

${ }^{56}$ 1609/04/08. Castro Urdiales. María de la Llosa, viuda de Domingo Suárez, y Martín de Santullán: Domingo había servido como marinero durante la Jornada de Inglaterra en 1587 en el patache La Concepción, de Antón de Carasa, en el San Jerónimo y en La Esperanza, de 02/05/1586 a 15/11/1590; Martín participó en la misma Jornada como despensero en las zabras San Andrés y San Juan, hasta 20/08/1590. Los testamentarios de Felipe II les habían mandado pagar por cédula, dada en Madrid, 16/02/1609 (AHPC, prot. 1.705, fol. 9-10).

${ }^{57}$ 1594/03/20. Castro Urdiales. Juana Cardo, viuda de Francisco de Oconos, vecina de Santullán, el cual se había asentado como marinero de S.M. en 1586 en el navío de Antón de Carasa, vecino de Castro, sirviendo en Portugal, Lisboa, Puerto de Santa María, Jornada de Inglaterra y vuelta de Noruega, y cuando le despidieron del navío se embarcó en el navío de Lope de la Torre, maestre Domingo de Laredo, y fue a la Tercera en conserva de los demás navios, adonde le canj[e]aron y metieron en la Almiranta que tuvo el general Bertendona (AHPC, prot. 1.699, poderes, doc. 5).

1607/05/03. Castro Urdiales. Juana Cardo, viuda de Francisco de Ozoños, vecina de Santullán, alistado en unas pinazas y pataches como marinero para la Jornada de Inglaterra, luego sirvió de marinero en la zabra de Domingo de Somarriba y en el patache de Antón de Carasa, vecino de Castro, y más tarde le pasaron al navío de Bastián Diego, vecino de Laredo, y en la refriega que se tubo con la Almiranta del henemigo se ahogó; otorga poder a Martín de Miranda, vecino de Castro y viandante en Madrid (AHPC, prot. 1.704 (1607), fol. 345-346).

${ }^{58}$ Martin y Parker, mapa de naufragios, p. 382. Hablan de la zabra Nuestra Señora de Castro, pero estimo que debe de haber confusión, por cuanto esta zabra se hundió a la vista de España. 


\section{— zabra La Asunción (maestre Pedro del Río).}

Conocemos el deambular de esta nave gracias a la hoja de servicios de Rodrigo de Pin, compañero de armas de Miguel de Basániz, marinero del patache Nuestra Señora de Begoña. Pin, vecino de Castro, se había alistado en mayo de 1586 como artillero de la zabra de Pedro del Río; vuelto de la Jornada, fue licenciado y se marchó sin más a su casa. ${ }^{59}$

Diego de la Helguera, vecino de Castro, artillero en esa zabra, y su hijo sobrevivieron a la Jornada de Inglaterra, pero no a las operaciones posteriores. ${ }^{60}$ Martín de Castro y su hijo Juan, vecinos de la misma villa, también sirvieron en esa nave, como despensero y grumete, pero desconocemos si llegaron a Santander sanos y salvos con la nave, tan sólo que la viuda de Martín sobrevivió a padre e hijo.${ }^{61}$ Siguiendo con las parejas de alistados, Juan de Hoz se enroló en esta zabra, en Guipúzcoa, yendo acompañado de su criado, Juan de Campuzano, vecino de Laredo, ${ }^{62}$ aunque no es seguro que participasen en la Jornada.

Sancho Barba, al que ya hemos localizado en el patache San Jerónimo, finalizado el luctuoso suceso, se pasó como contramaestre a esta zabra, yendo a Lisboa, hasta que la nave fue despedida. ${ }^{63}$ Pedro del Río, por su parte, ya era maestre de esta nave cuando en mayo de 1587 fue embargada por la Corona; estaba cargada para llevar mercancías a Galicia y Andalucía, obteniendo licencia de la justica castreña para realizar el viaje y volver a tiempo de incorporarse a la armada. ${ }^{64}$

\footnotetext{
${ }^{59}$ AHPC, prot. 1.699, poderes, doc. 18. Ver nota 42.

${ }^{60}$ 1594/03/31. Castro Urdiales. María de San Lucas, vecina de Castro, viuda de Diego de la Helguera, alistado en mayo de 1586 para servir de artillero en un patache, maestre Pedro del Río, vecino de Castro, llamado La Asunción, donde fue a Lisboa, Jornada de Inglaterra, mar de Noruega y España.

Fue con su hijo, del mismo nombre, como grumete, que murió de enfermedad tras ser despedidos del patache. El padre se embarcó en el navío de Toribio Gómez, vecino de Santander, del que era maestre; en el mismo fue a la Isla Tercera y luego le pasaron al galeón El Caballero del Mar, y venieron en él los henemigos, le abombardearon sobre el Cabo de San Vicente y se afondaron, adonde se ahogó (AHPC, prot. 1.699 , poderes, doc. 22).

${ }^{61}$ 1618/05/19. Castro Urdiales. Catalina de Mena, viuda de Martín de Castro, vecina de Castro, por cuanto en 1586 su marido y su hijo, Juan de Castro, sirbieron a S.M. en la Jornada de Yngalaterra, de que fue general el Duque de Medina Sidonia, en el patache nombrado Nuestra Señora de la Asunción, de que fue capitán y maestre Pedro del Río, en la esquadra y pataches que llevó a su cargo a la dicha Jornada don Antonio Hurtado de Mendoça, y el dicho mi marido fue sirviendo por despensero y el dicho mi hijo de grumete, cuyos sueldos se los debían en parte y ella era heredera de ambos, por ello otorga poder para cobrar a Domingo de Castro, su hijo natural, vecino de Castro y residente en Madrid (AHPC, prot. 1.709 (1618), doc. 51).

${ }^{62}$ 1594/03/19. Castro Urdiales. Mencía de Urdiales, viuda de Juan de Hoz, por cuanto éste se había alistado en Guipúzcoa con el contador Bernabé de Albia y sirvió de piloto en un patache, maestre Pedro del Río, vecino de Castro, llamado La Asunción de Nuestra Señora, con un criado suyo, llamado Juan de Campuzano, natural de Laredo, y fue a Lisboa bajo la bandera del general Oquendo, donde estuvo seis meses hasta que el general falleció (AHPC, prot. 1.699, poderes, doc. 2).

${ }^{63}$ AHPC, prot. 1.699, poderes, doc. 44.

${ }^{64}$ 1587/05/04. Castro Urdiales. Pedro del Río, vecino de Castro y maestre del patache La Asunción, que al presente está presto, berga alta, para el Reyno de Galicia y a la Andalucía, con carga de fierro, brea,
} 


\section{— zabra La Trinidad (maestre Martín Alonso de Lastero ${ }^{65}$ ).}

Hemos localizado a cuatro de los marineros que formaron parte de su tripulación: Antón de Montellano, vecino de Lusa, era uno de los retornados sin licencia en 1587; tenía 26 años entonces, seco de rostro y barba roja. Desde el 11/05/1586 sirvió como despensero en esta zabra, en la que hizo la Jornada de Inglaterra, para acabar muriendo ahogado en el galeón San Juan Colorado. ${ }^{66}$

Julián de Villar Otañes, vecino de Santullán, fue como contramaestre de esa nave, en compañía de Domingo de Cueto, seguramente criado suyo, alistado como grumete; ${ }^{67}$ se enrolaron en 25/05/1586, siendo despedidos en El Ferrol, cuando Julián ostentaba el cargo de piloto de la misma nave, en 09/08/1590, junto con la zabra. ${ }^{68} \mathrm{Al}$ año siguiente volvemos a encontrar a Julián concertando un fletamento para llevar suministros a la armada en Galicia y Portugal. ${ }^{69}$ En 1592, siguiendo con su ocupación de

acero, pipas y otras mercancías, cargadas en Bilbao y en Castro de Martín de Noja y Sancho de Hornoas, mercaderes; pide a la justicia licencia para partir, obligándose a descargar sólo en este Reino y no en el extranjero. Contesta el alcalde que, pues maestre y cargadores eran de Bilbao y Castro, no era necesaria la licencia, pero, para mayor seguridad, se la da y ordena al maestre se obligue a traer testimonio de la justicia donde descargare. Pedro se obliga (AHPC, prot. 1.697 (1587), doc. 55).

${ }^{65}$ También era conocido simplemente como Alonso de Lastero; fue maestre de la zabra San Juan (propiedad de Lope García de la Torre y Julián de Aparicio), que ba en esta presente Jornada de que es cabo don Antonio Hurtado de Mendoza, en serbicio de S.M., llevando a Lisboa los marineros cántabros en agosto de 1586; el día 25 de ese mes los parcioneros le habían otorgado poder para ir como mandador de su nave (AHPC, prot. 1.717 (1586), fol. 103).

${ }^{66} 1607 / 05 / 04$. Castro Urdiales. Teresa de la Helguera, viuda de Antón de Montellano, vecino de Lusa, alistado como marinero y despensero en la zabra La Trinidad, maestre Alonso de Lastero, otorga poder a Martín de Miranda (AHPC, prot. 1.704 (1607), fol. 350-351).

[1609. Castro Urdiales]. Teresa de la Helguera, vecina de Castro, viuda de Antón de Montellano, otorga poder a Martín de Miranda para cobrar $21.078 \mathrm{mrs}$. de los testamentarios de Felipe II (AHPC, prot. 1.705, fol. 1-2).

${ }^{67}$ 1607/04/26. Castro Urdiales. Julián de Villar Otañes, vecino de Santullán, otorga poder para cobrar los sueldos por los servicios prestados por él mismo y por Domingo de Cueto, como marineros, contramaestre y del grumetaje en la Jornada de Inglaterra, en la que participaron yendo en la zabra La Trinidad, maestre Martín Alonso de Lastero, desde 25/05/1586 (AHPC, prot. 1.704 (1607), fol. 331-332).

${ }^{68}$ 1590/08/09 y 15. El Ferrol. Fe y pasaporte del general don Alonso de Bazán a favor de Julián de Villar Otañes, vecino de Santullán, piloto de la zabra La Trinidad, de que no tenía plaza en la armada y orden a las guardas para que le dejen pasar (AHPC, prot. 1.704 (1607), fol. 280r).

Queda borrada la plaça de Jullián de Villar Otáñez, vezino de Santullán, piloto de la çabra La Trinidad, porque fue despedido juntamente con la dicha çabra. En 9 de agosto 1590. Don Juan Maldonado Barnuevo. Don Alonso de Baçán, etc.

Por quanto Jullián de Villar, que es el constado en la fee de esta otra parte, no tiene plaça en esta armada, los guardas le dexarán passar libremente, juntamente en su çabra. El Ferrol, a 15 de agosto 1590. Don Alonso de Baçán (traslado sacado en Castro Urdiales, 27/10/1590) (AHPC, prot. 1.697 (1590), doc. 80).

${ }^{69}$ 1591/07/21. Castro Urdiales. Julián de Aparicio, dueño de la zabra Nuestra Señora de la Concepción, surta en la concha, con hierro, acero y brea, y Julián de Otañes Villar y san Juan de Lastero, mercaderes y marineros, todos de Castro, se conciertan bajo ciertas condiciones para llevar la carga a los Reinos de Galicia y de Portugal (AHPC, prot. 1.698 (1591), doc. 30). 
mercader proveedor de la armada, concertó otro fletamento para llevar mantenimientos a las tropas españolas que operaban en Bretaña, en Morbihan, Concarneau y Blauet, hoy Port-Louis. ${ }^{70}$ Diego de Esquerra, vecino del Valle de Sámano, también sirvió como artillero en esta zabra y luego en la misma plaza en la de San Juan Bautista, sin que se pueda determinar en cuál de las dos participó en la batalla de Inglaterra. ${ }^{71}$

\section{- zabra La Concepción de Valmaseda (maestre Juan de Valmaseda).}

Esta nave, como bien decía Casado Soto, no tomó parte propiamente en la batalla de Inglaterra y avatares posteriores, por haber sido utilizada de correo entre Flandes, España y Francia durante aquellos días, como deja bien claro la hoja de servicios presentada por Martín de Llano, piloto de la misma:

Martín de Llano, mayor en días, vecino de Castro, alistado en 04/05/1586 en una zabra (maestre Juan de Valmaseda, vecino de Castro), como piloto; en ella fue a Lisboa llevando bastimentos desde Galicia y por escolta de los galeones de Portugal; los llevaron a Lisboa y luego al Puerto de Santa María, en donde estuvieron al tienpo que llegó el henemigo y acavado que [fue] hiço vela después de haver estado en campaña; desde Lisboa fueron a La Coruña y a la Jornada de Inglaterra; pero les mandaron ir a Dunquerque, Laredo y Santander, donde Juan de Cardona les ordenó ir por bastimentos a Asturias; vueltos a Santander, don Alonso de Bazán fue a La Coruña y Lisboa, teniendo que volver la zabra a El Ferrol, y allí fueron con Sancho Pardo a Francia, hasta que volvieron con el capitán Chavarria; tornaron a Francia con el alférez Tomé de Paredes a conducir armas y dinero, entregándolo todo en el puerto de Blauet, luego volvieron a España y de nuevo a Francia con dinero; avisado el Rey, por cédula particular, mandó despedir la zabra. ${ }^{72}$

El mismo día que Martín otorgaba poder a Marecheaga lo hacían también sus compañeros de fortuna, san Juan de Loizaga y Rodrigo de Carranza, también vecinos de Castro, alistados en la zabra como escribano y marinero; he aquí su exposición, que viene a complementar la anterior:

San Juan de Loizaga y Rodrigo de Carranza, vecinos de Castro, alistados en la zabra La Concepción, en mayo de 1586, san Juan por marinero y escribano y Rodrigo por marinero, fueron a Lisboa y Puerto de Santa María; y, partida la Armada, en la mar le dieron horden que fuesen a Dunquerque en compañia de un filipote, y bolvieron con despachos del Príncipe de Parma a la villa de Laredo, y de la dicha villa y de la de San-

\footnotetext{
70 1592/03/05. Castro Urdiales. Bartolomé de San Juan, maestre de la zabra San Buenaventura, surta en el puerto con carga de acero, hierro y paño, y Julián de Otañes Villar y Gabriel de Hornillas, vecinos de Castro, a los que fleta el navío para llevar la carga a Maublete [Blauet, hoy Port-Louis, en manos españolas entre 1590-1598], Morbihan y Concarneau (Bretaña), bajo ciertas condiciones (AHPC, prot. 1.698 (1592), doc. 19).

${ }^{71}$ 1594/03/24. Castro Urdiales. María de Carranza, viuda de Diego Esquerra, vecina del Valle de Sámano, salido en mayo de 1586 como marinero y artillero de la zabra de Alonso de Lastero, vecino de Castro, que fue a Lisboa y a Cádiz a traer bastimentos; luego sirvió el mismo oficio en la nave de san Juan de Carasa y, andando en ella, murió en la ciudad de Sevilla (AHPC, prot. 1.699, poderes, doc. 17).

72 1594/04/01. Castro Urdiales (AHPC, prot. 1.699, poderes, doc. 24).
} 
tander fueron al puerto de Baublet con el alférez Paredes y llevaron dinero y armas para el exército español, y bolvieron a España y, estando en ella, los llevó el general Cibiaur a Francia, en donde estuvieron y bolvieron con recaudos y con el capitán Francisco de Chávarri. ${ }^{73}$

El día siguiente hizo lo propio Tomás de Castro, vecino de Castro, marinero de la misma zabra. ${ }^{74}$ El último marinero documentado en esta nave es Francisco Velaz, también vecino de Castro, que acabó su servicio con ventaja de contramaestre. ${ }^{75}$

- zabra San Andrés (dueños Lope de Peñarredonda y Juan de las Muñecas; maestre Domingo de Somarriba).

Esta nave aportó a Santander, tras pasar por la mismas penalidades que las demás de esa costa; tan sólo tres de los miembros de su tripulación dieron poderes para la reclamación de sus haberes atrasados: Aparicio de Sierra, piloto de la nave, murió años después de peste en Castro, junto con sus tres hijos; había servido en la armada, al menos, entre 04/05/1586 y 21/03/1587. ${ }^{76}$ Martín de Santa Cruz, también vecino de Castro, se enroló como escribano de esta zabra; terminada la Jornada de Inglaterra, volvió a Bretaña con Sancho Pardo, seguramente en la zabra La Concepción de Valmaseda. ${ }^{77}$ Ya en 1576 le habíamos encontrado sirviendo en la zabra Santa María de Castro (capitán y maestre Sancho de Aparicio), dentro de la armada que patrullaba el Cantábrico. ${ }^{78}$ El último marinero documentado es Martín de Santullán, que había ido como despensero de esta zabra y la de San Juan, hasta ser licenciado en 20/08/1590. ${ }^{79}$

${ }^{73}$ 1594/04/01. Castro Urdiales (Ibidem, doc. 23).

${ }^{74}$ 1594/04/02. Castro Urdiales. Tomás de Llano, vecino de Castro, alistado en mayo de 1586 en la zabra La Concepción, fue a Lisboa, Puerto de Santa María, y se halló quando el henemigo surgió en la baxía de Cádiz, adonde anduvo en campaña, Lisboa, La Coruña, Jornada de Inglaterra, Dunquerque, Lisboa y El Ferrol; allí le pasaron a la zabra cuyo maestre era Martín de Solórzano, en calidad de contramaestre, y fueron a la costa de Ynglaterra a tomar lenguas y hicieron ciertas presas, con las quales bolvieron al Ferrol; sirvió con el general Bertendona en la nave de san Juan de Carasa hasta que lo despidieron (Idem, doc. 25).

${ }^{75}$ 1594/07/04. Castro Urdiales. Francisco Velaz, vecino de Castro, alistado en mayo de 1586 como marinero en la zabra La Concepción, y al cavo de algunos meses le señalaron ventaja de contramaestre, sirviendo en Lisboa, Jornada de Inglaterra y en Francia con Sancho Pardo (Idem, doc. 40).

${ }^{76}$ 1607/05/29. Castro Urdiales. María de Peñarredonda, viuda de Aparicio de Sierra, vecina de Castro, alistado como piloto en la zabra San Andrés, de Domingo de Somarriba, vecino de Castro, participó en la Jornada de Inglaterra y en otras; sus tres hijos habían muerto de peste, además del padre; otorga poder a Miranda (AHPC, prot. 1.704 (1607), fol. 389-390).

1609/03/08. Castro Urdiales. María de Peñarredonda, viuda de Aparicio de Sierra, piloto de la zabra San Andrés, vuelve a otorgar poder a Miranda (AHPC, prot. 1.705, fol. 5-6).

${ }^{77}$ 1594/05/31. Castro Urdiales. Martín de Santa Cruz, vecino de Castro, alistado en mayo de 1586 por escribano en la zabra San Andrés (dueños Lope de Peñarredonda y Juan de las Muñecas, maestre y mandador Domingo de Somarriba, vecino de Castro), fue a la Jornada de Inglaterra, volviendo, luego fue a Bretaña en compañía de Sancho Pardo (AHPC, prot. 1.699, poderes, doc. 39).

${ }^{78}$ 1576/07/30. Castro Urdiales (AHPC, prot. 1.695, fol. 384). Ver nota 11.

${ }^{79}$ 1609/04/08. Castro Urdiales (AHPC, prot. 1.705, fol. 9-10). Ver nota 56. 


\section{- zabra Santa Catalina (maestre Juan de Hornoas).}

Este barco, junto con el San Juan de Carasa, terminó la Jornada inglesa en el puerto de Dunquerque; tan sólo tenemos documentado a su piloto, san Juan de Villegas, vecino de Castro, cuya hoja de servicio nos resulta muy instructiva:

San Juan de Villegas, vecino de Castro, alistado en 1586 como piloto de la zabra Santa Catalina, (maestre Juan de Hornoas, vecino de Castro), fue a Lisboa y luego con el Marqués de Santa Cruz al Cavo de San Vicente en busca de unas naves regocesas que iban con bastimentos a Lisboa; luego fue con el Marqués a la Isla Tercera en busca de don Álvaro de Flores, que venía por general de la flota de Indias; más tarde, fue a Lisboa y participó en la Jornada de Inglaterra y por se haver desparra[ma]do ciertas naves, les llegó orden fuesen en busca dellas y las encontraron y venieron a juntar con la demás armada. ${ }^{80}$

Villegas sobrevivió a la Jornada, llegando a otorgar finiquito a Marecheaga, que había conseguido para él en 1596 el pago de 13.000 mrs. ${ }^{81}$ Para 1607 ya había fallecido, cuando su viuda pidió se discerniera curador para sus dos hijas menores; nombrada como tal, otorgó poder para cobrar nuevos atrasos del servicio de su marido en aquella contienda, diciendo que había ido como piloto de la zabra La Trinidad. ${ }^{82}$ Entra dentro de lo posible que se equivocara en ello o, tal vez, fuera cambiado de destino sobre la marcha.

\section{- zabra Santa María de Castro o Nuestra Señora de Castro (dueño y maestre} Rodrigo Galván).

Esta nave sufrió el destino más trágico de todas las cantábricas que participaron en la Jornada de Inglaterra, pues, tras sufrir todos los avatares del resto, se hundió a la vista de la costa española, cuando ya faltaba poco para desembarcar, muriendo de esta penosa manera toda la tripulación.

Formaban parte de la misma: Juan de Lexos, escribano de la misma, cuya viuda, Antona de Hoz, expuso en el poder otorgado a Marecheaga cómo su marido había participado en la Gran Armada, y, viniendo en compañía del Duque de Medina Sidonia, general, al reconocer de la costa de España, en temporal recio se afondó y en

\footnotetext{
${ }^{80}$ 1594/04/04. Castro Urdiales (AHPC, prot. 1.699, poderes, doc. 28).

${ }^{81}$ 1596/05/15. Castro Urdiales (AHPC, prot. 1.700 (1596), doc. 55). Ese mismo día Villegas otorgó poder a su mujer, Catalina de la Tienda, para percibir de Pedro de las Cuestas 200 reales que le había prestado en Galicia (en el Reyno de Galicia, estando en la armada real, para que los diese a la dicha mi muger) (Ibidem, doc. 53).

${ }^{82}$ 1607/05/28. Castro Urdiales. Catalina de la Tienda, viuda de san Juan de Villegas, que murió en servicio real yendo como piloto en su armada, solicita curador para sus dos hijas menores, Juana y Catalina, de 16 y 18 años; tenía otra mayor, de 25 años, que estaba casada (AHPC, prot. 1.704 (1607), fol. 383 386).

En el día, Catalina, una vez discernida la tutela de sus menores, otorga poder a Martín de Miranda para cobrar de los testamentarios de Felipe II veinte y tantos mil mrs. que se le debían del servicio de su marido en la zabra La Trinidad, yendo como piloto en la Jornada de Inglaterra (Ibidem, fol. 444-445).
} 
ella perecieron todos los que en ella andavan y el dicho su marido. ${ }^{83}$ Con palabras parecidas se expresa la madre de Gonzalo de Rasines, vecino de Castro, artillero de esta desdichada zabra. ${ }^{84}$ También la madre de Juan de Hoz, vecino de Castro, usa términos similares.$^{85}$ Es posible que también sirvieran en esta nave Martín de la Quin$\operatorname{tana}^{86}$ y Juan de la Quintana, vecinos del Valle de Sámano. ${ }^{87}$

- zabra San Juan de Carasa o San Juan Bautista de la Esperanza (dueños san Juan de Carasa Samames y Lope de Ocina, maestre Diego de Carasa, hermano de san Juan ${ }^{88}$ ).

De esta nave contamos con información más abundante, aunque no siempre es posible discernir si los servicios prestados por su tripulación fueron o no en la Jornada de Inglaterra. Así ocurre, por ejemplo, con el marinero Mateo de Sopeña, vecino del Valle de Sámano, ${ }^{89} \mathrm{o}$ con los Lezama —Juan de Lezama, padre, maestre; Juan de Lezama, hijo, contramaestre, y Tomás de Lezama, hijo de aquél, paje $-{ }^{90}$ o con Diego

${ }^{83} 1594 / 03 / 19$. Castro Urdiales (AHPC, prot. 1.699, poderes, doc. 3).

${ }^{84}$ 1594/03/21. Castro Urdiales. Catalina Barba, viuda de Pedro de Rasines, cuyo hijo Gonzalo de Rasines, de que era heredera, se había asentado en mayo de 1586 como marinero y artillero en el navío de Francisco Galván, vecino de Castro, se ahogó tras volver de Inglaterra y Noruega, viniendo con la Capitana, que se hundió a la vista de España en un recio temporal, en que se ahogó toda la tripulación (AHPC, prot. 1.699 , poderes, doc. 11).

${ }^{85}$ 1594/04/30. Castro Urdiales. Juana de Carasa, viuda de san Juan de Hoz y madre de Juan de Hoz, difuntos, vecina de Castro; el hijo se había alistado en la zabra Santa María, dueño Rodrigo Galván, en 1586, la cual, volviendo de la Jornada de Inglaterra, a bista de España, con tienpo mal recio se avía perdido y aogado la gente della y el dicho su hijo (AHPC, prot. 1.699, poderes, doc. 34).

${ }^{86}$ 1590/02/07. Castro Urdiales. Pedro de la Quintana, vecino del Valle de Sámano, hermano de Martín de la Quintana, que había fallescido en servicio del Rey, nuestro señor, en la mar, beniendo de la Jornada de Ynglaterra, el cual había dejado un hijo de 12 años, de su mismo nombre, reclama a la justicia se le tenga por su pariente más próximo a fin de poder reclamar los sueldos debidos al difunto (AHPC, prot. 1.697 (1590), doc. 11).

${ }^{87}$ 1590/02/07. Castro Urdiales. Catalina de Hoz, viuda de Juan de la Quintana, vecina del Valle de Sámano, el cual había fallecido en la Jornada de Inglaterra, dejando dos hijos menores, san Juan y María, reclama el sueldo del marido y pide a la justicia la nombre curadora ad litem de sus hijos (AHPC, prot. 1.697 (1590), doc. 12).

${ }^{88}$ Ambos parcioneros le otorgaron poder para llevar su nave el 25/08/1586, poco antes de partir con la marinería para Lisboa (AHPC, prot. 1.717 (1586), fol. 133).

Martin y Parker incluyen dentro de la escuadra de Levante la nave San Bautista de la Esperanza, fabricada en Castro Urdiales, que fue embargada en 14/06/1588 e hizo toda la campaña (pp. 451 y 534). A mi juicio, se trata de un claro error.

${ }^{89}$ 1617/09/04. Castro Urdiales. Francisca de Gárate, vecina del Valle de Sámano, cuyo difunto marido, Mateo de Sopeña, había servido en la armada, en la nave San Juan Bautista de la Esperanza, en plaza de marinero, otorga poder a Gaspar de Carasa, vecino de Castro, para cobrar 37.327 mrs. (libranza de 1617/07/29. San Lorenzo) (AHPC, prot. 1.709 (1617), doc. 98).

${ }^{90} 1617 / 09 / 07$. Castro Urdiales. Ines de Musques, viuda de Juan de Lezama, en nombre de su hijo ausente, de nombre similar, y de Tomás de Lezama, también hijo de los mismos, los cuales habían servido en la armada real como maestre, contramaestre y paje, respectivamente, en la nave San Juan Bautista de la Esperanza, otorgan poder a Gaspar de Carasa para cobrar 47.911 mrs. (30.000 para maestre y contra- 
de Pino, vecino de aquel Valle. ${ }^{91}$ Para 1590 iba por capitán de la misma, García de Carasa, hijo del propietario de la nave, que premurió a su padre. En ese año se concertaba García con Gregorio Martínez, vecino de Castro, para llevarle por marinero en la armada real. ${ }^{92}$

Sí nos consta que Martín de Santullán sirvió de despensero en esta nave hasta 20/08/1590, luego de haberlo hecho en la zabra San Andrés ${ }^{93}$ y Francisco de Quintana, vecino de San Martín de Ontón, como alguacil del agua, tras haber servido en el mismo puesto en el patache La Concepción de Carasa. ${ }^{94}$ Julián Malos, por su parte, se alistó como lombardero en esta nave, pasándose, luego de la Jornada, a la escuadra de Bertendona. ${ }^{95}$ Martín de Candéliz, también vecino de Castro, se había embarcado en mayo de 1586, pero falleció en La Coruña al tiempo que Hurtado de Mendoza, sin llegar a salir para Inglaterra. ${ }^{96}$ Diego de Esquerra, vecino del Valle de Sámano,

maestre y 17.000 para el paje) (libranza de la misma fecha que la anterior, librada por los pagadores de descargos de Felipe II) (AHPC, prot. 1.709 (1617), doc. 99).

${ }^{91}$ 1617/09/04. Castro Urdiales. Diego de Pino, vecino del Valle de Sámano, que había servido en la armada real en plaza de grumete, en la nave San Juan Bautista de la Esperanza, propiedad de san Juan de Carasa, otorga poder para cobrar lo librado por la Junta de descargo a Gaspar de Carasa, vecino de Castro y estante en Madrid, 8.679 mrs. (libranza de los mismos en idéntica fecha) (AHPC, prot. 1.709 (1617), doc. 97).

${ }^{92}$ 1590/03/20. Castro Urdiales. Gregorio Martínez, vecino de Castro, dice que san Juan de Carasa, también vecino y dueño de la nave San Juan Bautista de la Esperanza, surta en la ría y canal de Bilbao, a sueldo del Rey, que lleva por capitán a García de Carasa, hijo de san Juan de Carasa, le había propuesto que fuese a servirle como marinero, con 5 pagas de 4 ducados cada una.

Acepta y se obliga a servir en la nave a las órdenes de dicho capitán todo el tiempo que estuviese a sueldo del Rey y no se ausentará hasta que el Rey le dé licencia, so pena de devolver los sueldos recibidos, además de la pena correspondiente. Confiesa haber recibido los 20 ducados de las 5 pagas, de lo que es testigo el escribano, y lo demás que el susodicho sirviere se yrá cobrando como la demás parte marinera. Se da por contento del dinero recibido, a reales de a 8 y 4 nuevos (AHPC, prot. 1.697 (1590), doc. 30).

1618/01/27. Castro Urdiales. San Juan de Carasa, vecino de Castro y dueño de la nao San Juan de la Esperanza, padre del difunto capitán García de Carasa, que sirvió en la armada real como capitán y maestre de dicha nao, otorga poder a su hijo Gaspar para cobrar libranza de $191.323 \mathrm{mrs}$., a cuenta de lo debido (libranza de 1617/10/27. Ventosilla) (AHPC, prot. 1.709 (1618), doc. 5).

${ }^{93}$ 1609/04/08. Castro Urdiales (AHPC, prot. 1.705, fol. 9-10).

${ }^{94}$ 1609/07/18. Castro Urdiales (AHPC, prot. 1.705, fol. 191-192). Ver nota 54.

${ }_{95}$ 1594/03/22. Castro Urdiales. María de Laiseca, viuda de Julián Malos, que se había asentado en la nave de san Juan de Carasa de marinero y lombardero, y partió de la ría de Bilbao con bastimento para El Ferrol, sirvió en Lisboa, Puerto de Santa María, La Coruña y Jornada de Inglaterra; vuelto a España, siguió en la escuadra del general Bertendona, yendo a la Isla Tercera y, vuelto a El Ferrol, falleció de enfermedad (AHPC, prot. 1.699, poderes, doc. 12).

${ }^{96}$ 1594/03/19. Castro Urdiales. María de Sopeña, viuda de Martín de Candéliz, vecina de Castro, por cuanto éste embarcó en 14/05/1586 en la zabra San Juan (de Juan de Carasa, maestre Diego de Carasa, su hermano), y en las otras que llevaba don Antonio Hurtado de Mendoza, fue a Lisboa, donde estuvieron mucho tiempo, luego fueron a Galicia, más tarde volvieron a Lisboa con los galeones nuevos, y al Puerto de Santa María, voviendo a Lisboa, bajo la bandera del Adelantado de Castilla, y luego a La Coruña, donde falleció, otorga poder a Juan de Marecheaga a fin de cobrar de la Corona los sueldos adeudados a su difunto marido (AHPC, prot. 1.699, poderes, doc. 1). 
fue como artillero en las zabras La Trinidad y San Juan Bautista, falleciendo en Sevilla, sin que sepamos en cuál de las dos naves participó en la Jornada. ${ }^{97}$

En una indeterminación parecida nos encontramos hablando de los cuñados Andrés de Barbadillo y Domingo de Colunga, vecinos de Castro; éste se había enrolado como lombardero en la zabra de Diego Marmolejo de Sevilla (maestre Martín de Solórzano), que se hundiría en Cascais en febrero de 1587, siendo trasladado al galeón San Martín, de la Corona de Portugal, buque insignia del duque de Medina Sidonia; Barbadillo fue como marinero en la zabra de San Juan de Carasa, también a cargo de don Antonio Hurtado de Mendoza; como éste, ambos fallecieron durante el servicio, pero no sabemos cuándo. ${ }^{98}$ Ambas naves retornaron a España. En cambio, sí nos consta que Ochoa de Acosta y su hijo, Juan de Acosta, enrolados de piloto y paje en esta zabra de Carasa, hicieron el trayecto completo hasta regresar a Santander con la Capitana; luego anduvieron un año más en Francia..99

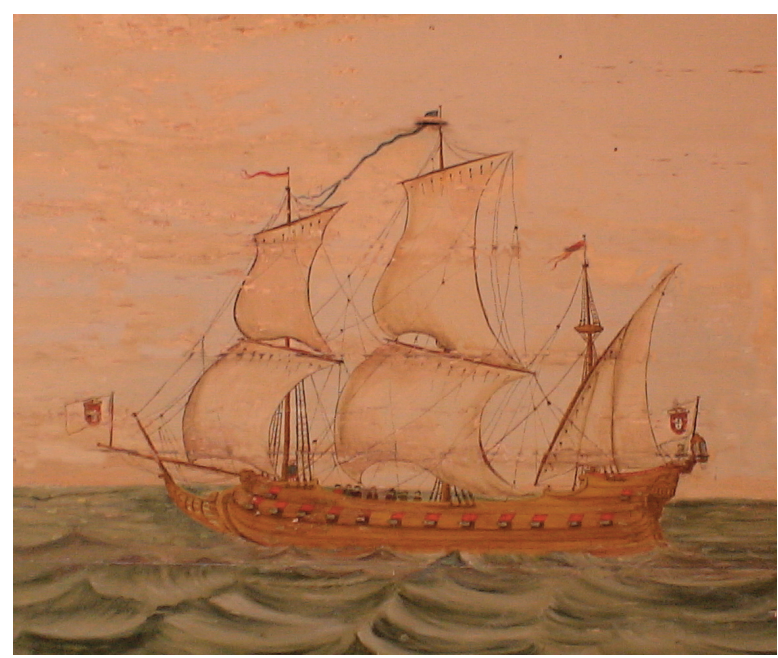

Buque portugués

\footnotetext{
${ }^{97} 1594 / 03 / 24$. Castro Urdiales (AHPC, prot. 1.699, poderes, doc. 17). Ver nota 71.

${ }_{98}$ 1594/03/24. Castro Urdiales. María de Argomedo, viuda de Domingo de Colunga, vecina de Castro, en nombre de su marido y de Andrés de Barbadillo, su cuñado, otorga poder a Marecheaga (AHPC, prot. 1.699 , poderes, doc. 16).

${ }_{99}$ 1594/04/29. Castro Urdiales. Ochoa de Acosta, vecino de Castro, y su hijo, Juan de Acosta, alistados en 06/05/1586 en la zabra San Juan, maestre Diego de Carasa, yendo de piloto y paje, respectivamente, fueron a Lisboa, Puerto de Santa María, Lisboa, Jornada de Inglaterra, Noruega y viniendo en conserva de la Capitana hasta Santander; luego los mandaron con Sancho Pardo al puerto de Baublet, en Francia, donde estuvieron un año, trayendo al cabo un correo a Santander, donde fueron despedidos (AHPC, prot. 1.699 , poderes, doc. 33).

1596/05/15. Castro Urdiales. Ochoa de Acosta, vecino de Castro, que en 1594 había dado poder para cobrar lo debido de su sueldo de marinero en la Jornada que hiço a la enpresa del Reyno de Ynglaterra el Duque de Medina Sidonia, a Juan de Marecheaga, el cual había cobrado en su nombre 54.000 mrs., le otorga finiquito (AHPC, prot. 1.700 (1596), doc. 54).
} 
Por su parte, Pedro de Liendo, vecino de Castro, alistado en mayo de 1586, según su viuda, había servido como despensero y piloto en la zabra de Francisco de Lastero Jimeno y con Juan de Hornoas en la zabra de san Juan de Carasa, donde participó en la Jornada, toma de lenguas y otros hechos de armas, falleciendo finalmente en La Coruña. ${ }^{100}$

— zabra San Juan (propietario Diego Marmolejo de Sevilla, maestre Martín de Solórzano $\left.{ }^{101}\right)$.

La actuación de esta nave resulta un tanto enigmática, pues, como acabamos de decir, un bajel con el mismo nombre, propietario y maestre había ido a Lisboa con marineros cántabros en agosto de 1586, bajo las órdenes de don Antonio Hurtado de Mendoza, hundiéndose en Cascais, no lejos de la capital lisboeta. Hemos visto cómo el lombardero Colunga fue pasado a la Capitana tras el naufragio de dicha nave ${ }^{102} \mathrm{y}$, sin embargo, también hemos mencionado cómo Tomás de Llano había servido en la nave de Solórzano como contramaestre, yendo a tomar lenguas a Inglaterra. ${ }^{103}$

Pero es que hay más testimonios. Gonzalo de Santa Clara, vecino de Castro, aseguraba haber servido de escribano en esta nave:

100 1594/05/02. Castro Urdiales (AHPC, prot. 1.699, poderes, doc. 35). Da la sensación de que esta señora, María de Olea, no andaba muy bien informada, pues el dueño del patache La Concepción de Lastero era Francisco de Lastero Valverde —o tal vez es que había vacilaciones en la atribución del segundo apellido- y Juan de Hornoas fue maestre de la zabra La Trinidad, no de la de san Juan de Carasa.

Pedro otorgó testamento en 1599, por hazer ausencia en servicio de S.M. y en los galeones que ban y salen de la rya y canal de Vilbao, y temiéndose de la muerte, que es cosa natural (AHPC, prot. 1.701 (1599), doc. 70).

${ }^{101}$ También los hijos del capitán Martín de Solórzano hubieron de reclamar los salarios del padre, siendo finalmente recompensados con una merced especial:

1604/01/07. Castro Urdiales. Pedro de Solórzano menor, hijo del capitán Martín de Solórzano, otorga poder para cobrar lo adeudado de los servicios de ambos en las armadas reales de Felipe II (AHPC, prot. 1.704 (1604), fol. 10-11).

En 11/06/1605, en Castro, se hace constar que S.M. había concedido 400 ducados para los hijos del capitán Martín de Solórzano, por los servicios prestados en las armadas reales (AHPC, prot. 1.704 (1604), fol. 83).

${ }^{102}$ Caso similar fue el de Juan de San Marco, vecino de Castro.

1594/03/20. Castro Urdiales. Juan de San Marco, vecino de Castro, que se había alistado en esa villa para servir en la armada de S.M. (04/05/1586) en una zabra (maestre Martín de Solórzano), como piloto, yendo a Lisboa, donde estuvo seis meses hasta que la zabra se hundió en Cascais; luego, por cédula del Marqués de Santa Cruz, sirvió de entretenido en los navíos que iban a la Tercera de aviso y a otras partes durante un año; más tarde le mandaron pasar a la zabra San Andrés, maestre Domingo de Somarriba, como piloto, por haber fallecido el que llevaban, yendo por cabo el capitán Esteban Ochoa de Pilas, en la que sirvió en la Jornada de Inglaterra, mar de Noruega y demás ocasiones, y últimamente en el galeón Santiago el maior de la Corona de Castilla. Durante los cinco años de su servicio había actuado con puntualidad, sin hacer ausencia (AHPC, prot. 1.699, poderes, doc. 4 y 42 bis). El segundo poder, de 14 de julio, similar al primero.

${ }^{103}$ Ver nota 74. 
Gonzalo de Santa Clara, vecino de Castro, alistado como escribano en la zabra San Juan (maestre Martín de Solórzano, dueño Diego Marmolejo de Sevilla): fue a Lisboa, Isla Tercera, Lisboa, Jornada de Inglaterra, y, estando en el Canal, se les hordenó llevasen al capitán Pedro de León con enbaxada a Dunquerque al Príncipe de Parma, y le llebaron; y después le mandó don Jorje Manrique, beedor general, fuesen a Nantes y le aguardasen alli; $y$ en el Canal pelearon con las henemigos, y fueron a la dicha Nantes y tomaron un barco, de que se tomó avisso, y esperaron en Nantes como dos meses y al cabo truxeron al dicho don Jorje y a Bernabé de Pedrosa y a Juan de Huerta y al secretario del Duque de Medina Sidonia a la villa de Santander; luego se volvió a casa con licencia.

Más tarde, acudió en pocos días en el mismo navío a llevar plomo y cuerdas a La Coruña, donde dieron a Martín de Solórzano la zabra Santa Ana, capitán Ojeda, y asentó plaza de escribano, fue a la costa de Inglaterra de aviso y andubo en ella asta que los yngleses le tomaron.

Exactamente la misma hoja de servicios presentó Rodrigo Tonelado, vecino de Castro, enrolado en la misma nave como marinero en mayo de 1586. ${ }^{104}$ Tonelado, hombre de 20 años en 1587, era de buen cuerpo y gesto, poca barba y roja, cuando fue reembarcado para Lisboa en la zabra de Solórzano, que se perdió. Martín de Barduntes, vecino así mismo de Castro, a la hora de reclamar sus salarios atrasados también esgrimió los mismos servicios prestados en esa misma nave, supuestamente perdida. ${ }^{105}$

Si Llano, Santa Clara, Tonelado y Barduntes no mentían - y considero difícil que pudiesen engañar a los pagadores del ejército- esa nave debió de existir y hacer la Jornada de Inglaterra, al menos, en sus inicios, para luego ser destinada, como las otras dos zabras ya comentadas, para correo entre España, Flandes y Francia. La única explicación plausible es que Marmolejo de Sevilla, luego del naufragio de su zabra en Portugal, botase una nueva con el mismo nombre y la entregase al mismo Solórzano. Ahora bien, ¿cómo es posible que nadie hiciera constar su existencia en los registros regios? Al menos, los que han llegado hasta nosotros. No tengo respuesta para esta incógnita.

El expediente personal de Gaspar de Avero - Aveiro-, vecino de Castro, tampoco arroja mucha luz sobre este problema. Según el poder otorgado a Marecheaga en 1594, se alistó como artillero en la nave de Francisco de Martiarto, vecino de Portugalete - supongo que uno de los pataches de la misma flotilla, de los que no tenemos otras noticias-, en el que hizo el trayecto completo y continuó luego en otros lugares, hasta ser despedido. ${ }^{106}$ Pero, cuando dos años más tarde revocó dicho poder, para atribuírselo a Otañes, relató que había sido piloto en la nave de Martiarto, donde realizó la Jornada, volviendo de Inglaterra y yendo luego al encuentro de la flota de Indias, más tarde se había embarcado en la zabra de Martín de Solórzano. ${ }^{107}$

\footnotetext{
${ }^{104}$ 1594/07/24. Castro Urdiales (AHPC, prot. 1.699, poderes, doc. 46).

105 1594/07/24. Castro Urdiales (Ibidem, doc. 47).

106 1594/07/24. Castro Urdiales (Idem, doc. 45).

107 1594/04/02. Castro Urdiales. Gaspar de Avero, vecino de Castro, alistado en mayo de 1586 como artillero en la nave de Francisco de Martiarto, vecino de Portugalete; partiendo de Castro fueron a Lisboa,
} 
Por último, las gestiones para cobrar sus salarios atrasados por parte de García de Ampuero, vecino de Castro, nos informan también de la existencia de otra nave vascongada, además de la de Martiarto: la del capitán Juan Pérez de Mutio, vecino de San Sebastián, perdida en Francia tras regresar de la Jornada; Ampuero tomó dos nuevos destinos en galeones reales en los años siguientes. ${ }^{108}$

\section{- zabra San Martín de Santander.}

Esta nave se incorporó a la armada real en marzo de 1588, en Laredo; participó en los combates y se hundió en las costas irlandesas. Tampoco consta en los registros manejados, si bien sabemos de su existencia por el poder otorgado por Aparicio de Llantada y su mujer, María de Carasa, para cobrar los sueldos de Rodrigo y Antón de Carasa, piloto y grumete de la zabra, padre y hermano de María. ${ }^{109}$

- marineros sin adscripción conocida a nave.

Como es lógico suponer, a medida que pasaba el tiempo desde que sucedieron los combates de la Gran Armada fueron desapareciendo los interesados y sus causahabientes fueron perdiendo memoria de los servicios prestados por éstos. Así, en los poderes que se otorgaron pasados más de 20 años los datos aparecen muy simplificados, de modo que, de no haberse conservado otro poder otorgado anteriormente, es imposible saber la nave concreta en que los marineros sirvieron. Esto ocurre en cinco ocasiones.

Diego de Trucíos, vecino de Castro, había servido de marinero y en otros oficios entre $06 / 05 / 1586$ y $08 / 11 / 1590 .{ }^{110}$

San Juan de Hazas, alistado como artillero, contramaestre y piloto en distintos bajeles de la Gran Armada. ${ }^{111}$

Isla Tercera y Lisboa, donde invernaron; en 1588 fue a la Jornada de Inglaterra, Noruega y vuelta a España, hasta Santander; volvió a El Ferrol, siguiendo en guarda de la flota de Indias a las Islas de Faial y Flores (en las Azores), adonde encontraron al henemigo y de alli con tiempo contrario arribaron al puerto de Portugal, donde fueron despedidos y los marineros tornaron a sus casas (AHPC, prot. 1.699, poderes, doc. 26).

${ }^{108}$ 1596/09/09. Castro Urdiales (AHPC, prot. 1.700 (1596), doc. 113). Este personaje tiene una larga trayectoria documental, pues consta en 1576 cuando participó en la armada que patrulló el Cantábrico desde la zabra Santa María de Castro (AHPC, prot. 1.695, fol. 384), así como en 1598, cuando en La Coruna presentó ante la justicia el testamento de Pascual Beltrán (AHPC, prot. 1705, fol. 187-190).

109 1594/05/02. Castro Urdiales. García de Ampuero, vecino de Castro, alistado en mayo de 1586 en la nave del capitán Juan Pérez de Mutio, vecino de San Sebastián, que partió de allí con la armada del general Juan Martínez de Recalde, fue a La Coruña, Isla Tercera y se juntó con la armada para la Jornada de Inglaterra, vuelta de Noruega y después a Francia, donde la nave se perdió.

En 1589 se alistó en Santander con Juan de las Suertes, maestre de uno de los galeones de la escuadra de Sevilla, donde sirvió de lombardero. En 1591 se alistó en el galeón Santo Tomás, maestre Francisco de la Sierra (AHPC, prot. 1.699, poderes, doc. 37).

${ }^{110}$ 1594/03/28. Castro Urdiales (AHPC, prot. 1.699, poderes, doc. 19).

111 1609/04/27. Castro Urdiales. Diego de Trucíos, vecino de Castro, como heredero de su hijo otorga poder (AHPC, prot. 1.705, fol. 95-96). 
Antón de Manzanal, vecino de Castro, enrolado como grumete y marinero en la Jornada de Inglaterra. ${ }^{12}$

Agustín Cacho, vecino de Castro, contramaestre y calafate durante dicha Jornada, sirvió hasta 14/05/1589. ${ }^{113}$

Agustín Cacho, vecino de Castro, marinero durante la Jornada. ${ }^{114}$

Cuentan algunos guías turísticos turcos, en su intento por minimizar la importancia de la batalla de Lepanto, que el sultán, cuando supo de su derrota, exclamó con notable petulancia que sin demora haría reconstruir en oro todos los navíos perdidos. Sin llegar a los extremos propios de la imaginación oriental, puede decirse que la reacción suscitada en el ánimo de Felipe II, una vez supo del desastre que se había producido en torno a las Islas Británicas, fue similar, si no en bravatas, sí al menos en cuanto a la determinación de no darse por derrotado y seguir manteniendo la defensa de los intereses de la Corona, frente a un revés que, probablemente, prefería considerar momentáneo y puntual.

A través de las fuentes conservadas en Castro Urdiales sabemos de esa determinación, reflejada en la construcción de nuevos navíos, ${ }^{116}$ en el alistamiento de marineros -y las medidas tomadas para hacer efectivo el cumplimiento de su compromiso de servir en la armada- y en el continuo embargo real de naves mercantes. No estoy interesado en desarrollar lo sucedido después de 1588, tan sólo aportar algunos datos que vienen a corroborar lo ya sabido en este punto.

De nuevo, los poderes para cobrar salarios atrasados nos ilustran de los servicios de marinería; por sólo citar una decena de casos, mencionemos las siguientes hojas de servicio:

112 1609/09/14. Castro Urdiales. María de San Martín, viuda de san Juan de Hazas, e hijos otorgan poder (AHPC, prot. 1.705, fol. 201-202).

${ }^{113}$ 1609/09/26. Castro Urdiales. Inés Martínez del Portillo, vecina de Castro, viuda de Julián de la Puerta, otorga poder. Inés era heredera de Antón, pues como prima suya era su pariente más cercano (AHPC, prot. 1.705, fol. 209-210). Creo que este Antón es distinto del grumete que sirvió con Sancho de Somarriba.

114 1609/09/27. Castro Urdiales. Juana de Bispo, viuda de Andrés de Cabañas, vecina de Castro, otorga poder a Miranda. María Escobedo, primera mujer de Cabañas, había sido heredera forzosa de los Cacho (AHPC, prot. 1.705, fol. 213-214).

${ }^{115}$ 1609/10/04. Castro Urdiales. García del Atalaya y Catalina de la Colina, vecinos de Castro, otorgan poder a Miranda. Cacho fue el primer marido de Catalina (AHPC, prot. 1.705, fol. 218-219).

${ }^{116}$ 1607/03/08, 12 y 28. Castro Urdiales. El veedor Diego de Noja Castillo contrata con Antón de Talledo, vecino del Valle de Otañes, Pedro de Herrada, vecino del Valle de Sámano, y Ochoa Ortiz de Mioño, vecino de Castro, el suministro para la armada real de 4.000, 1.500 y 13.000 codos de tabla, respectivamente (AHPC, prot. 1.704 (1607), fol. 315-316, 317-318 y 313-314).

Previamente, se incluye relación de los árboles tallados en la zona (fol. 304-312).

1618/10/02. Castro Urdiales. El concejo y cabildo de mareantes de Castro Urdiales nombra procurador para juntarse en Bárcena (Trasmiera) con los representantes de las otras tres villas de la costa, que se habían ofrecido a servir al Rey con 6 galeones y 2 pataches con sus tripulaciones, tal y como había hecho el Señorío de Vizcaya (AHPC, prot. 1.709 (1618), doc. 88).

Siguen instrucciones al procurador (doc. 89) 


\author{
Sancho de Pontejo, vecino de Mioño. ${ }^{117}$ \\ Fabián de la Herrán, vecino de Mioño. ${ }^{118}$ \\ Martín Ruiz de Hozpín, vecino de Santullán. ${ }^{119}$ \\ Juan de Guzmán, vecino de Santullán. ${ }^{120}$ \\ Francisco Cacho, vecino de Lusa. ${ }^{121}$ \\ Diego de la Pedrueca, menor en días, vecino del Valle de Otañes. ${ }^{122}$ \\ Domingo de Carranza, vecino del Valle de Sámano. ${ }^{123}$
}

117 1594/03/21. Castro Urdiales. María de Villaviciosa, viuda de Sancho de Pontejo, vecina de Mioño, asentado para servir en los galeones nuevos fabricados en Santander (11/06/1590), en los que fue a El Ferrol; de allí le llevaron en una zabra en Felipote, que se decía El Cavallero de la Mar, de cargo de Pedro de Zubiaur, yendo a Francia y de vuelta a Santander murió en el trayecto (AHPC, prot. 1.699, poderes, doc. 9).

118 1594/03/21. Castro Urdiales. Catalina de Hoz, viuda de Fabián de la Herrán, vecina de Mioño, que en abril de 1591 se había asentado para servir en los galeones nuevos hechos en Santander, general Antonio de Urquiola, donde partieron para El Ferrol; allí le pasaron a una zabra, maestre Juan de Valmaseda, para ir a Francia, muriendo a su vuelta a Santander (AHPC, prot. 1.699, poderes, doc. 10).

119 1594/03/22. Castro Urdiales. Martín Ruiz de Hozpín, vecino de Santullán, que se había asentado en 20/07/1589 en Castro Urdinales, llegado a Santader le alistó don Juan Maldonado, general de la armada, en el galeón San Cristóbal como marinero-carpintero, bajo el general don Alonso de Bazán; fue a La Coruña, reconocieron la Isla Tercera y volvió a Lisboa y El Ferrol, de donde con licencia se volvió a invernar a su casa (AHPC, prot. 1.699, poderes, doc. 13).

${ }^{120}$ 1594/03/22. Castro Urdiales. María de Horno, vecina de Santullán, viuda de Juan de Guzmán, alistado en 20/07/1589 como marinero en un barco que salió de Santander, en el galéon San Cristóbal, maestre Juan de las Suertes, para La Coruña y Lisboa e invernar en El Ferrol; luego volvió a embarcar en el mismo galeón y le pasaron al filibote La Hilandera, donde fue a Francia, donde estuvo un año y allí murió (AHPC, prot. 1.699, poderes, doc. 14).

${ }^{121}$ 1594/03/23. Castro Urdiales. María Ortiz Gómez, vecina del concejo de Lusa, madre y heredera de Francisco Cacho, alistado en 1589 como marinero y lombardero, salió de Santander el día de la Magdalena en la compañía de don Alonso de Bazán, capitán general; fue a El Ferrol, Isla Tercera y Lisboa, retornando a El Ferrol e invernando en su casa; en 1591 tornó a embarcar en los galeones nuevos hechos en Santander, con el general Urquiola, y le pasaron al filibote El Cavallero del Mar, a cargo de Pedro de Zubiaur, y murió sobre Baublet (AHPC, prot. 1.699, poderes, doc. 15).

122 1594/03/31. Castro Urdiales. Juan de la Pedrueca, tutor de Magdalena de la Pedrueca, y María de las Herrerías, viuda de Diego de la Pedrueca, menor en días, vecinos del Valle de Otañes, alistado en 11/04/1591 entre la gente que levantó don Luis Fajardo, corregidor que fue, para atripolar los galeones nuevos que salieron de la ría y canal de la villa de Santander, el cual Diego goçaba de ventaja por su abilidad, fue a El Ferrol, Lisboa e Isla Tercera, donde sirvió un año (AHPC, prot. 1.699, poderes, doc. 21). ${ }^{123} 1594 / 04 / 09$. Castro Urdiales. Pedro de Carranza, vecino del Valle de Sámano, padre del difunto Domingo de Carranza, alistado en abril de 1590 como grumete en el galeón Santiago, luego con plaza de lombardero, más tarde en el filibote León Nepio, en Francia; en el galeón San Andrés fue como artillero a Pasajes y sirvió en La Calamandria y en la urca San Lorenzo y, viniendo con el general Bertendona en enero de 1594, se perdió la urca junto a Pasajes y se ahogó en ella (AHPC, prot. 1.699, poderes, doc. 31$)$.

1590/05/08. Castro Urdiales. Diego de Carranza, vecino de Castro, por cuanto a su ruego Martín Sáenz de Villanueva, también vecino, había salido por fiador de Domingo de Carranza, natural del Valle de Sámano, de que serviría en la armada real sin ausentarse, Diego también se obliga (AHPC, prot. 1.697 (1590), doc. 47). 
Francisco de Villanueva, vecino de Castro. ${ }^{124}$

Pedro de Somarriba, vecino de Castro. ${ }^{125}$

Bartolomé de Comillas, vecino de Castro. ${ }^{126}$

Esta pequeña muestra viene a completar los servicios ya conocidos, desempeñados por los supervivientes de la Gran Armada, que se reengancharon después.

Sería largo y prolijo relacionar aquí el listado de personas que, tras cobrar sus pagas adelantadas, dejaron de acudir a cumplir con su cometido, así como las medidas que tomó la Corona para asegurar su concurso, en los años que median entre $1590 \mathrm{y}$ 1617. ${ }^{127} \mathrm{La}$ alta mortalidad sufrida por los marineros en las armadas anteriores y los peligros que se arriesgaban a correr hacían que el acudir al servicio de marinería ya no fuera tan atrayente como cuando se coronó con éxito la campaña de la Isla Tercera.

Finalmente, relacionar sólo las zabras castreñas que, arrestadas para el servicio real de armada, prestaron fianza en marzo de 1591, a fin de obtener licencia para llevar las naves a sus destinos y desembarcar sus cargamentos, obligándose a retornar en breve a su base para incorporarse a dicha armada. Como se puede apreciar, aunque en la Jornada de Inglaterra sólo se habían perdido un patache y una zabra castreñas, en este caso se impuso la rotación y de las siete enroladas ninguna repitió servicio.

— zabra San Pedro (maestre Colás Gómez, vecino de Castro).

- zabra Santa Ana (maestre Pedro de Llantada).

— zabra La Trinidad (maestre san Juan de Herrado). ${ }^{128}$

124 1594/04/20. Castro Urdiales. Francisco de Villanueva, vecino de Castro, alistado en 1590 en una de las nueve pinazas besugueras que había salido de la ría y canal de Santander a cargo de Domingo Núñez de Avendaño, junto con la armada de don Alonso de Bazán para El Ferrol; éste le repartió en el galeón San Juan Colorado, de la Corona de Portugal, maestre Pedro de Bringas y capitán Pablo de Aramburu; fueron a la vuelta de las naves de Indias y a Lisboa; luego le pasaron al navío San Clemente, maestre Pedro Prieto, donde fue a Francia a conducir infantería y bastimentos y estuvo en otras ocasiones; más tarde estuvo en el galeón San Pablo, fabricado en Santander, y anduvo en él (AHPC, prot. 1.699, poderes, doc. 32).

${ }^{125} 1607 / 04 / 26$. Castro Urdiales. Pedro de Somarriba, cabo de la parte marinera que salió del puerto de Castro Urdiales por mandato de Fernando de la Riba Herrera y Diego de Noja Castillo, en nombre de los marineros y artilleros (que detalla), los cuales se embarcaron en una pinaza besuguera de Castro en Santander e ido a La Coruña a servir en los galeones del portugués Juan Núñez Correa, donde estuvieron embarcados sin socorro 28 días, y luego pasaron debajo de la bandera del general Pablo de Aramburu, general de dichos galeones, que fueron a Lisboa a abastecerse y luego en socorro de don Luis Fajardo, general de la Armada del Mar Océano, hasta que lo dejaron en salvo, otorga poder para cobrar sus sueldos atrasados (AHPC, prot. 1.704 (1607), fol. 333-334).

${ }^{126}$ 1607/04/26. Castro Urdiales. Catalina de Avellaneda, viuda de Bartolomé de Comillas, vecina de Castro, el cual en 1606 se había embarcado como artillero en los galeones de la escuadra del general Bertendona, fue a Sevilla y de ahí en la armada del general don Luis Fajardo, en compañía del Almirante Vallecilla para las Indias, y en el camino encontráronse con el henemigo y los abordó y puso fuego al galeón del dicho Ballecilla, donde se quemó el dicho su marido con otra mucha gente. Otorga poder para cobrar atrasos (AHPC, prot. 1.704 (1607), fol. 341-342).

${ }^{127}$ Ver documentos del Apéndice III.

${ }^{128}$ Esta nave ya había estado arrestada en junio de 1587, cuando estaba cargada de sal rumbo a Portugal. 
— zabra Santa Ana (maestre Aparicio de Trucíos).

- zabra La Esperanza (maestre Pedro de Avellaneda).

- zabra La Concepción (maestre Pedro de Vidania).

- zabra San Buenaventura (maestre Pedro de Somarriba, caucionero suyo Diego de las Cuevas). ${ }^{129}$

Sin embargo, a lo largo del año anterior ya se había tomado la misma providencia, destinada a todas las naves existentes, ${ }^{130}$ de las que documentamos las siguientes:

— navío de Juan de Manzanal (maestre Toribio del Mar). ${ }^{131}$

— zabra San Juan, de Antón de Ampuero. ${ }^{132}$

— zabra La Concepción, de Sancho de Lastero Valverde. ${ }^{133}$

— zabra Santa Ana, de Diego de Marrón (maestre Pedro de Llantada). ${ }^{134}$

1587/06/01. Castro Urdiales. San Juan de Herrado, dueño, maestre y parcionero del navío La Trinidad, cargado de sal traída de Portugal, arrestada por el alcalde para la armada real, se obliga y da fianzas de volver en 10 días, tras vender la sal (AHPC, prot. 1.697 (1587), doc. 63).

${ }^{129}$ AHPC, prot. 1.698 (1591), doc. 13-19 y 21; el último documento es, en realidad, el salvoconducto para La Concepción.

130 1590/02/12. Castro Urdiales. El capitán Martín de Irigoyen Olazábal requiere al alcalde mayor de Castro que obedezca y cumpla cédula real que prohibía que saliesen navíos del puerto.

El corregidor ordena lo mismo.

El alcalde mayor la obedece y cumple.

Había dos pinazas, que finalmente son destinadas a llevar calafates a El Ferrol (AHPC, prot. 1.697 (1590), doc. 32).

131 1590/03/09. Castro Urdiales. El comisario Francisco de Velasco exhibe cédula para requisar navíos a fin de llevar bizcocho para la armada de El Ferrol (Ibidem, doc. 22).

En el día ordena a Toribio del Mar, maestre del navío surto en el puerto, propiedad de Juan de Manzanal, que no salga, pues quedaba requisado para el transporte del bizcocho. A pesar de ello, el barco largó vela y se fue a Portugalete a descargar su mercancía. El comisario pide testimonio para castigar a su maestre (Idem, doc. 23).

132 1590/04/25. Castro Urdiales. Antón de Ampuero, vecino de Castro, dice que un bando había prohibido que navío ni barco saliese del puerto, y él tenía necesidad de ir con su zabra San Juan a San Sebastián a cargar de brea para el Reino de Galicia, y llevaba en su compañía a Toribio de la Helguera, Domingo de Escobedo, Pedro de Resámano y Juan de la Quintana, y había pedido licencia a la justicia para salir. En virtud de la misma se obliga a ir a San Sebastián y, truxéndole Dios en salvamento, a volver y presentarse ante la justicia. Da fiador (AHPC, prot. 1.697 (1590), doc. 41).

1590/05/17. Castro Urdiales. Juan de Bendesu, vecino de Castro, se obliga a que Antón de Ampuero, vecino también, volverá del Reino de Galicia, a donde va con hierro y otras mercancías, en 4 meses, no sucediendo caso fortuito, y estará a las órdenes que se le diesen (AHPC, prot. 1.697 (1590), doc. 42).

133 1590/05/01. Castro Urdiales. Sancho de Lastero Valverde, vecino de Castro, dueño y maestre de la zabra La Concepción, surta en el puerto, dice que, estando arrestados los navíos por orden real, él había pedido licencia para salir al capitán Diego del Pontón, alcalde de Castro, y se lo había concedido para ir a San Sebastián a cargar hierro y otras mercancías para el Reino de Galicia, dando fianzas. Las da de volver de San Sebastián en 20 días (AHPC, prot. 1.697 (1590), doc. 43).

134 1590/05/04. Castro Urdiales. Pedro de Llantada, vecino de Castro y maestre de la zabra Santa Ana (su dueño Diego de Marrón), que había salido para San Sebastián, con condición de constituir fianzas de que volvería (AHPC, prot. 1.697 (1590), doc. 43bis).

El día 17 se obliga a volver de Galicia en 4 meses (idem). 


\title{
— pinaza de Juan de Sevilla y Diego Marmolejo de Sevilla (maestre Aparicio de Mena). ${ }^{135}$
}

— nave de Antón de Peñarredonda. ${ }^{136}$

— patache Espíritu Santo, dueño y maestre Martín de Cuartas. ${ }^{137}$

— zabra San Juan, de san Juan de Carasa. ${ }^{138}$

- carabelas portuguesas Santo Antonio (dueño Pedro Alvares, maestre Domingo Sinois, de Buarcos) y La Fermosa (dueño Pedro Fernandes, maestre Cristóbal Alonso, de Buarcos). ${ }^{139}$

\author{
— carabela (maestre Pablos González). ${ }^{140}$ \\ — patache San Pedro (maestre Bernardo de Villota). ${ }^{141}$
}

${ }^{135}$ 1590/05/08. Castro Urdiales. Juan de Sevilla, como principal, y Diego Marmolejo de Sevilla, como fiador, se obligan a que su pinaza volvería al puerto, pues debía partir para San Sebastián y habían pedido licencia; iba de maestre Aparicio de Mena. Volvería en 30 días (AHPC, prot. 1.697 (1590), doc. 49). 136 1590/05/17. Castro Urdiales. Antón de Peñarredonda, vecino de Castro, que había dado fianzas para ir a San Sebastián, llevar luego hierro a Galicia y volver después, ratifica la fianza (AHPC, prot. 1.697 (1590), doc. 50).

${ }^{137}$ 1590/05/18. Castro Urdiales. Martín de Lastero, vecino de Castro, dice que Martín de Cuartas, dueño y maestre del patache Espíritu Santo, estaba de partida para Galicia con hierro, acero y otras mercancías. Se obliga a que en 4 meses, salvo caso fortuito, volverá con Cuartas, Francisco de Herrado, Diego de la Quintana, Íñigo de Vidania, Melchor de Mamurga y Martín de Lastero (AHPC, prot. 1.697 (1590), doc. 52).

138 1590/12/15. Castro Urdiales. García de Peñavera, escribano de armadas de las Cuatro Villas, en la nave San Juan, propiedad de san Juan de Carasa, vecino de Castro, donde venían el general Martín de Bertendona y Juan Martínez de Zurbarán, su alférez, toma lista de todas las personas que allí iban (sólo los nombres) (AHPC, prot. 1.697 (1590), doc. 88).

139 1590/02/09. Castro Urdiales. Juan García de Tineo, alguacil de Juan de Valcárcel, comisario de Bernabé de Pedroso, proveedor general de la armada y ejército, encargado de averiguar la duela que las avenidas de agua habían echado al mar, para llevarlas a El Ferrol, ordena a las dos carabelas portuguesas, surtas en el puerto de Castro, Santo Antonio (dueño, Pedro Alvares; maestre Domingo Sinois, portugués, natural de Buarcos) y La Fermosa (dueño, Pedro Fernandes; maestre Cristóbal Alonso, también de Buarcos), que no abandonen el puerto sin su licencia (pues quería usarlos para llevar la duela a El Ferrol). Los portugueses piden se les deje llevar a San Sebastián la carga de linaza que traían y prestan obligación de volver (AHPC, prot. 1.697 (1590), doc. 13).

140 1590/03/15. Castro Urdiales. Diego Rubín de Celis, vecino de Suances (marquesado de Santillana), encargado de los alfolíes de la sal de Suances y Puentesolía, requiere al alguacil Juan García de Tineo, creado para la inquisición de la duela que se perdió en Ribadeo, y se opone al embargo de la carabela de sal que tenía comprada para llevarla a los de S.M., pues se la quería embargar para llevar la duela. Tineo le da licencia para llevar la sal y le ordena traer el barco para cargar la duela de Bermeo.

Mandato y notificación al maestre Pablos González (AHPC, prot. 1.697 (1590), doc. 24).

${ }^{141} 1594 / 01 / 27$. Castro Urdiales. El capitán Domingo de Villota, vecino de Laredo, otorga poder a Carlos de Peñavera el mozo, estante en La Coruña, para sacar de poder de Juan Frexo y María Fouxo, vecinos de El Ferrol, ciertos papeles que dicho capitán y Juan de Noja les habían entregado en custodia, tocantes al patache San Pedro, maestre Bernardo de Villota, que anduvo en servicio real (trataban de lo recibido y gastado por el patache y otras cartas de pago y recaudos de vino y otras cosas que se entregaron en Santander y El Ferrol a maestres de naves y navíos, para dar cuenta de ello a S.M.) (AHPC, prot. 1.699, doc. 10). 
A partir de ese año 1591 se aprecia cómo los castreños experimentados en la navegación son atraídos al servicio real, no sólo para tripular sus propias naves mercantes debidamente artilladas, sino también para embarcarse en las naves de propiedad regia, galeones y zabras, como maestres o despenseros. Citemos algunos casos de fianzas otorgadas por éstos al hacerse cargo de las naves:

— galeón nuevo (maestre Diego de Pando). ${ }^{142}$

— zabra real Santa Clara (maestre Bartolo de Palacio). ${ }^{143}$

— filibote real Rodamundo (maestre Pedro del Cerrillo). ${ }^{144}$

- galeón San Simón (capitán Juan de la Sierra Salazar, maestre Santiago de Rasines). ${ }^{145}$

\section{— galeón Santa Catarina (capitán Pedro de Trucíos). ${ }^{146}$}

142 1591/12/31. Castro Urdiales. Diego de Pando, vecino de Castro, como principal, y Juan de Pando, morador del lugar de Allendelagua, como fiador, se obligan y dan fianza por las velas, aparejos, jarcia, artillería y munición de un galeón nuevo que el Rey había entregado a Diego para que lo llevara donde le mandara, por mandador y maestre (AHPC, prot. 1.698 (1591), doc. 44).

${ }^{143}$ 1595/07/24. Castro Urdiales. Bartolo de Palacio, vecino de Castro, dice que Fernando de la Riva Herrera, vecino de Santander, criado de S.M. y proveedor real, le había entregado en su real nombre una zabra para que le llevara como maestre y mandador a cosas de su servicio; por ello se obliga a dar buena cuenta de la zabra, artillería, municiones, bastimentos y pertrechos, presentando como fiador a Juan de Jimeno, vecino de Castro (AHPC, prot. 1.700 (1595), doc. 94).

1596/03/23. Castro Urdiales. Bartolomé de Palacio, como principal, y Francisco de Palacio, su hijo, Juan Galván y Juana de la Hoz, viuda de Antón de la Llana, vecinos de Castro, como fiadores, se obligan a pagar a Fernando de la Riva Herrera, criado de S.M. y proveedor de la costa de Poniente, que había encargado a Bartolomé la zabra Santa Clara, una de las que estaban en la ría y canal de Santander, para el real servicio, lo resultante de la cuenta de Bartolomé, si éste no lo hiciese (AHPC, prot. 1.700 (1596), doc. 34). 144 1595/10/18. Castro Urdiales. Pedro del Cerrillo, vecino del Valle de Sámano, dice que Fernando de la Riva Herrera, criado de S.M. y proveedor en la costa de Poniente, le había entregado el filibote Rodamundo, con cantidad de vituallas, municiones, pertrechos, además del navío, jarcia y aparejos, para andar por mandato real; por ello se obliga juntamente con Juan Treto, Miguel de Palacio y Domingo de Larrea, vecinos del mismo Valle (AHPC, prot. 1.700 (1595), doc. 95).

Tal vez sea éste el filibote que hubo de ser auxiliado por chalupas a su retorno de Francia, pocos meses después:

1596/01/12. Castro Urdiales. Juan de Vergón, vecino de Castro, maestre de la chalupa Santa Catarina, que había servido con ella y con 7 personas en dos días atuando, amarrando y favoreciendo un philibote de S.M. que venía del puerto de Blauet, con xarcia, remos y otras cosas de las galeras de Bretaña, en que se havían ocupado noche y día, por cuyo trabajo Diego de Noja Castillo, en nombre del Rey, les había pagado 40 reales, por los que dan carta de pago (AHPC, prot. 1.700 (1596), doc. 58).

145 1599/03/21. Castro Urdiales. Santiago de Rasines, vecino de Castro, dice que el general Martín de Bertendona y el proveedor en el Señorío de Vizcaya, Baltasar de Lezama, a cuyo cargo están las cosas de la guerra y provisión del dicho servicio, le habían nombrado maestre del galeón San Simón, capitán Juan de la Sierra Salazar, vecino de Castro, uno de los que se havían fabricado en la ría y canal de Vilbao [nombramiento, Bilbao, 19/03/1599], dando fianzas de 400 ducados de vituallas, xarcea, aparejos y munición, como lo demás de su cargo.

Se obligan de mancomún Santiago, Diego de Bringas, san Juan de Llantada y Juanche de Hornoas, vecinos de Castro (AHPC, prot. 1.701 (1599), doc. 95).

146 1604/01/06. Castro Urdiales. Pedro de Solórzano menor, vecino de Castro, como principal, y Pedro de Solórzano mayor y Andrés de Manzanal, como fiadores, por cuanto el general Martín de Bertendona 


\section{— galeón nuevo (Julián de Quirós). ${ }^{147}$}

No obstante, siguen aprestándose naves particulares para servicios de armas y traslado de suministros:

— zabra La Concepción (dueño y maestre Sancho de Lastero Valverde). ${ }^{148}$

— navío San Felipe (dueño san Juan de Carasa, maestre Juan de la Sierra). ${ }^{149}$

— zabra La Concepción (dueño y maestre Diego de Santa Clara). ${ }^{150}$

Como puede apreciarse, la mayoría de las medidas documentadas son de carácter ofensivo, siendo muy escasas las referidas a una política defensiva, para el caso de un contragolpe enemigo. En el último documento del primer apéndice recogemos cédula real a don Luis Fajardo, corregidor de las Cuatro Villas, en abril de 1590, encomendándole nombrase cabos de la infantería que había de ejercitarse en la defensa costera; la orden ya se le había remitido el 16 de marzo, pero ahora añade que el corregidor nombre los cabos por distritos, dependientes de los sargentos mayores, y que le remita relación de los nombrados.

le había nombrado maestre de raciones del galeón Santa Catarina, surto en la ría y canal de Portugalete, capitán Pedro de Trucíos, vecino de Portugalete, se obligan a estar a lo que resultare de su gestión como tal maestre de raciones (tachado: maestre de jarcia, que llevaba ésta, además de la artillería y munición).

Añade que sus fiadores son suficientes para los 400 ducados que se le piden (AHPC, prot. 1.704 (1604), fol. 7-9).

147 1618/04/08. Castro Urdiales. Julián de Quirós y Catalina de la Sierra, su madre, viuda de otro del mismo nombre, como principales, y Juan de Alcedo, Julián de Hornoas y san Juan Sierra Salazar, como fiadores, vecinos de Santullán y Lusa, por cuanto Julián había sido nombrado maestre de uno de los galeones que se estaban aparejando en las rías y astilleros de Bilbao y Portugalete, y era preciso que para asegurar el sustento de la gente de guerra y de mar que llevaría, que afianzase por valor de 500 ducados, en caso de quiebra suya, otorgan fianzas (AHPC, prot. 1.709 (1618), doc. 42).

148 1595/05/04. Castro Urdiales. Diego de Noja Castillo, en nombre de Juan Macatene, mayordomo de la artillería real de las Cuatro Villas, sostenedor de bastimentos en ella, y Sancho de Lastero Valverde, vecino de Castro, maestre y dueño de la zabra La Concepción, surto en el puerto, celebran contrato de fletamento para llevar bizcocho a Pasajes (AHPC, prot. 1.700 (1595), doc. 48).

149 1595/11/13. Castro Urdiales. San Juan de Carasa, vecino de Castro, dueño del navío San Felipe, que está cargado de birrio y otras mercancías para la villa de Blauet, del Reyno de Francia, y provisión del exército español que en Bretaña asiste, por mandado del Rey don Phelipe, que Dios guarde, otorga poder a Juan de la Sierra, vecino de Castro, para ir como maestre a vender su mercancía en Blauet y en el término del maestre de campo don Juan del Águila; con poder para cargar mercancías lícitas y fletarlo a naturales católicos.

Poder a Domingo Montes Vigil, criado de S.M., estante en Blauet, y a Juan de Mena, vecino de Castro, para actuar ante los jueces de Bretaña o Francia, católicos. Especialmente, para el proceso por el corso hecho por el difunto Melchor Cacharro con una galizabra suya (AHPC, prot. 1.700 (1595), doc. 106).

${ }^{150}$ 1602/03/07. Castro Urdiales. Diego de Santa Clara, maestre y dueño de la zabra La Concepción, dice que el proveedor Francisco de la Riva Herrera le había embargado su zabra para el servicio real y, como estaba cargada y fletada para el Reino de Galicia, pidió licencia para enviarla, obligándose a traerla en dos meses, o dar otra zabra similar para dicho servicio, ofreciendo como fiador a Juan de Lastero, vecino de Castro (AHPC, prot. 1.702, doc. 102). 
En virtud de dicha comisión, Fajardo nombró cabo de la gente de la Junta de Sámano a Gregorio de Otañes, vecino del Valle de Otañes, que podría nombrar subalternos -alférez, sargento y cabos de escuadra-, llevando cajas y bandera y realizando los alardes correspondientes; dependería del sargento mayor Diego de Velasco; se especifica que deberían acudir al socorro de Santander a la menor señal de rebato. Una anotación posterior, cuya referencia he perdido, indica que el sistema introducido en estas fechas resultó poco efectivo, por lo que se volvió a la práctica anterior, siendo general, alférez y sargento, respectivamente, el alcalde mayor, un regidor y el procurador general de la villa. ${ }^{151}$

La otra noticia de carácter defensivo con que contamos son las órdenes dictadas, en la primera mitad de agosto de 1592, por el corregidor de las Cuatro Villas, Diego de Orellana de Chaves, a la villa de Castro Urdiales para ponerse en defensa, ante el avistamiento de naves enemigas en la costa. ${ }^{152}$

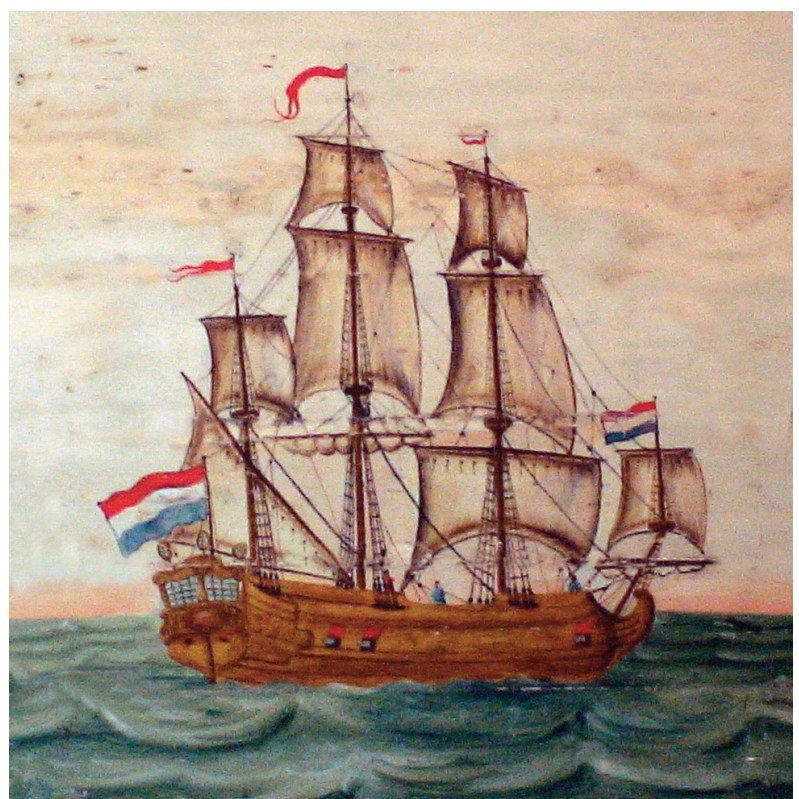

Buque holandés

\footnotetext{
${ }^{151}$ Apéndice I, doc. 3.

152 1592/08/02 y 12. Laredo. Sendas órdenes de Diego de Orellana de Chaves, corregidor de las Cuatro Villas, a Castro Urdiales para estar aprestados para la defensa, pues se habían avistado navíos de guerra enemigos de 50, 60 y 80 toneladas, que venían a causar daños en los puertos de Laredo y Castro (sello de placa) (AHPC, prot. 1.698 (1592), doc. 39).
} 


\section{APÉNDICE I}

\section{Documento 1}

1587/04/02. Laredo y 1587/04/04. Castro Urdiales

Treslado de un mandamiento y requerimiento que se hiço a don Antonio Hurtado de Mendoça por la parte de don Ordoño de Çamudio corregidor.

AHPC, prot. 1.697 (1587), doc. 53, 54 y 56.

\section{Documento 1/a}

1587/04/02. Laredo (doc. 53/1)

Don Ordoño de Zamudio, corregidor de las Cuatro Villas de la Costa de la Mar, ordena al alcaide de Castro Urdiales que requiera a don Antonio Hurtado de Mendoza que le remita a examen los marineros necesarios para la armada real, de acuerdo con las instrucciones regias.

Don Hordoño de Çamudio, cuyas son las casas de Çamudio y Çugasti, Martiarto y Guecho, cavallero de la Horden de Alcántara, corregidor en este Corregimiento de las Quatro Villas de la costa de la mar por el Rey, nuestro señor, y en virtud de las zédulas reales y cartas misibas que de S.M. tengo para lo que de yuso se conterná, hago saber a bos, el alcaide de la villa de Castro de Urdiales o vuestro lugarteniente, en cómo al serbicio de S.M. conbiene que requiráis como por la presente os lo mando a don Antonio Urtado de Mendoça que procure y enbíe ante mí todos los marineros suficientes a exsamen, que allare, para que se alisten y resciban sus pagas, las quales, conforme a lo que S.M. me tiene mandado, está presto y cierto de se las dar y conforme a lo que S.M. manda, siendo tales que las merezcan y con seguridad que las yrán a serbir, cómo e quando y adonde por S.M. les fuere mandado, sin poner dubda ni ostáculo de que no ay dinero para les dar las dichas sus pagas, porque yo estoy presto y cierto de se las dar, el qual dicho requerimiento me enbiad signado en pública forma, por ante escribano público, juntamente con su respuesta, porque ansí conbiene al serbicio del Rey, nuestro señor. Fecho en Laredo, a dos días del mes de abrill de mill e quinientos e ochenta y siete años. Don Hordoño de Çamudio. Por mandado del corregidor, Juan de Sant Martín.

\section{Documento 1/b}

1587/04/04. Castro Urdiales (doc. 53/2)

Antonio de Olarte Otañes, alcaide de Castro Urdiales, en cumplimiento del mandamiento anterior del corregidor, notifica a don Antonio Hurtado de Mendoza dicho mandamiento y pide al escribano García de Peñavera que le dé testimonio de su contestación.

Sigue la contestación del juez comisionado, denunciando la falta de colaboración en su misión por parte del corregidor Zamudio.

En la villa de Castro de Urdiales, a quatro días del mes de abrill de mill e quinientos e ochenta y siete años, Antonio de Olarte Otañes, alcaide en la dicha villa, en virtud de lo contenido en el mandamiento desta otra parte, exmanado de don Hordoño de Çamudio, su corregidor y de las quatro villas, mandó a mí, García de Peñabera, escribano público del número y ayuntamiento de la dicha villa, se le hiziese notorio y requiriese lo en él contenido a don Antonio Urtado de Mendoça, vezino de la dicha villa, y en el dicho cumplimiento yo el dicho escribano se lo notefiqué.

El qual, abiendo oydo lo que el dicho requerimiento contenía, dixo que, como al dicho corregidor le consta, él partió de la cibdad de Lisboa por mandamiento de S.M. y bino a estas quatro villas y señorío de Vizcaya con zédula y comisión particular, dada en Madrid, a veynte y dos de diziembre del año pasado, para prender y castigar y hazer bolver a su real serbicio todos los marineros que de la armada de 
su cargo se binieron de la cibdad de Lisboa y del Andalucía y del Reino de Galycia, la qual dicha comisión originalmente a mostrado a s.m. del dicho corregidor en sus propias manos para que la leyese y biese lo que en ella se contenía y la boluntad de S.M.; en virtud de la qual él ha ydo y ba procediendo por el horden que conbiene al serbicio de S.M. y que lo hubiera hecho y haría con más bentaja, como al serbicio de S.M. conbiene, si s.m. del dicho corregidor no le hubiera ydo y fuese a la mano, haziéndole estorbo, como se le haze, para que no se execute lo que por el dicho don Antonio a seído probeído e probey hechando bandos y pregones por las calles públicas destas villas para que no se haga ni cumpla lo que el dicho don Antonio ha probeído.

Y que en los diez y nueve de febrero deste año S.M., por una su real carta y por otras primero le ha ynbiado a mandar que lebante todos lo más marineros que fuere posible y procure recoxer todos los que se han benido de la dicha armada y que no alze la mano asta dar fin en ello, y en base de todo lo que fuere haziendo y, entre otras cosas que S.M. en dicha carta le escribe, es que por escusar ynconvinientes y porque no tenga que dificultar el dicho corregidor en ninguna cosa de las que tocaren a este despacho, le he mandado escrebir dexe al dicho don Antonio libremente entender en este negocio, dándole para ello el fabor e ayuda que le podiere para que se haga su real serbicio como conbiene, con el qual procure tener toda buena correspondencia y le dé parte de lo que fuere haziendo, que al dicho corregidor le ha mandado escrebir haga lo mesmo.

Y que la dicha carta mostró originalmente al dicho corregidor para que entendiese y le constase de lo que S.M. mandava, y le dio parte de todo lo que le parescía conbenía se hiziese, conforme y como S. M. se lo mandava.

Y que en tres de março por otra carta S.M. le escribe ansí mysmo que junte todos los marineros que se binieron de la dicha armada y lebante de nuevo todos los demás que le fuese posible, y baya con todo ello y con toda brebedad a la cibdad de Lisboa; que al dicho corregidor l'escribe probea de veinte mill quinientos y quarenta y ocho reales, que tiene en su poder, y que con ellos comience el dicho don Antonio ha hazer los bastimentos para la gente y socorra con parte dello a la gente que de nuevo se lebvantare, en el ynterin que S.M. manda prober del dinero qu'el dicho don Antonio le abisare que es necesario probersele.

La qual dicha carta mostré tanbién originalmente en la villa de Laredo al dicho corregidor y comunicó con él lo que le parescía conbenía se hiziese para que con toda brebedad hubiese efecto lo que S.M. mandava, y le dixe los ynconbenientes que se seguían y se podrían seguir contra el serbicio real si no daba horden de cobrar luego el dinero, pues dezía no lo tenía en su poder, y que desde treze del pasado que rescibió el pliego de S.M., e le escrebía lo que en el pliego que juntamente con el que para él bino, se contenía fuera justo que ubiera acabado de cobrar el dinero que S.M. dezía tenía en su poder.

Y de nuebe del dicho mes de março rescibió otra carta de S.M., por la qual le manda tome quatro patajes para llebar la gente que se bino de la armada, y lo que de nuevo más se lebantare, y, si paresciere al dicho don Antonio sea menester más nabíos, patajes y zabras, que los haga aprestar y tome los que fueren menester, y que tome de los beinte mill y tantos reales que se le ha abisado por S.M. en poder del dicho don Hordoño, y que ansí mysmo dé toda la prisa posible para que se ponga todo a punto con mucha brebedad y parta con todo ello para la cibdad de Lisboa.

La qual assí mysmo mostró en la dicha Laredo originalmente al dicho corregidor para que la diese y entendiese lo que S.M. mandava, la qual y todas las dichas cartas el mysmo corregidor a leydo y con él a tratado y díchole todo lo que conbiene para conseguir lo que se pretende del serbicio de S.M. con la brebedad que conbiene y le correspondiese con este dinero, porque en virtud de lo que S.M. le abía mandado abía capitulado y concertado, con que dueños de nabíos que se los abían de dar y poner a punto para los diez días deste mes de abrill, con duzientos marineros en ellos, suficientes y listados ante escribano, con que se les diese el dinero nescesario para ello, y, aunque se lo ha pedido por muchas vezes, no lo ha querido probeer, antes a dicho que el dinero no está en su poder y que está una parte en poder del depositario de la villa de Laredo y otra parte en la villa de Santander en poder de Hernando de la Riba Herrero, y la mayor parte en la villa de San Bicente en diferentes personas que lo deben por obligaciones, y que ha ynbiado a procurar de juntarlo y cobrarlo al Lcdo. Escalante y que ha tornado a ynbiar 
a Pedro del Casal para dar más prisa y que traya el dinero, y que asta tanto que él no tiene con qué poder acudir a nada.

Y por otra carta de S.M. de veinte e tres del mes pasado que rescibió a los beinte e ocho d'él l'escribe al dicho don Antonio que ponga luego a punto todo lo que se la ha ynbiado a mandar y que lo comience ha hazer con los dichos beinte mill y tantos reales que ay en poder del corregidor, y a la ora que la rescibió escribió al dicho corregidor a la villa de Laredo con el correo que llebó el pliego de S.M. para él, dándole quenta de lo que contenía la dicha su carta y lo mucho que conbenía la brebedad, y que luego le mandase prober destos dichos veinte mill y tantos reales para acudir a lo que se le manda ansí para lo que toca a los bastimentos como para començar a dar a los dueños de los dichos quatro patajes para que començasen a alistar la gente, y así mysmo que mirase conbenía al serbicio de S.M. que los marineros truxesen las armas a su poder, como se lo abía mandado; a lo qual le respondió que por el tienpo haber hecho malo entendía tardaba Pero del Casal, a quien abía ynbiado por este dinero a las villas de Santander y San Bicente, y que no podía consentir que las armas los marineros las traxesen a su casa, porque él tenía horden de S.M. para que no se hiziese; y después l'escribió el dicho don Antonio al dicho corregidor otra carta, en que le tornó a pedir lo mesmo y que mirase que hera mucha tardança y que S.M. se deserbía en ello; y que luego le probeyese del dinero para acudir con ello ha hazer todo lo que conbiene; y el dicho corregidor no le ha querido ni quiere responder a ella, aunque ha más de quatro días que rescibió la dicha carta, todo lo qual ha seído y es contra lo que S.M. tiene mandado al dicho corregidor y dar causa que no se consiga su real boluntad con la brebedad que al dicho don Antonio le manda y tanbién al mysmo corregidor, y que ynbiara aora a que se le haga el dicho requerimiento e, si querer tomar más dilación y causar más estorbo y que se ponga en papel y dibulgue entre todos lo que S.M. les manda hazer, y que esto no conbiene a su real serbicio, sino que cada uno dellos cumpla y haga lo que les está mandado con suma diligencia y que ansí el dicho corregidor lo haga, porque el dicho don Antonio está presto para executar y cunplir todo lo que S.M. le ha mandado, y pedir al dicho corregidor que el dicho don Antonio enbíe a Laredo los marineros a exsaminar y listarse y rescebir sus pagas, si las merescieren, es querer hazer lo que conbiene se haga en dos días, que nunca aya efecto, pues save y es notorio que delante del dicho Pero del Casal le dixo el concierto que ha hecho con los dueños de los dichos quatro nabíos con los duzientos marineros en ellos, y que asta tanto que el dicho don Antonio les diese el dinero para que pudiesen buscar y alistar los marineros que con él contrataron no podían llebar a alistar ningún honbre a la villa de Laredo, porque para listar los marineros en sus lugares, donde cada uno son, se alistan ante escribano y resciben su dinero ante todas cosas y aun los que los hazen gastan con ellos mucha copia de mrs. y les dan muchos reales adelantados, además de lo que S.M. les da y tan buen día que con todo esto se puedan allar los marineros que conbienen y, sabiendo esto y constándole al dicho corregidor, no sabe el dicho don Antonio de que sirbe si no es de quererse tener en su poder el dicho corregidor este dinero o dexarlo de cobrar de los que lo tienen o causar dilación mucho más de la que conbiene, todo lo qual se debe obiar y dar horden que se cunpla lo que S.M. le tiene mandado. Y, en quanto a lo que dize de los marineros que sean suficientes y bayan a exsamen ante él, esto al dicho don Antonio yncunbe, pues los ha de llebar a su cargo y nabegar y andar con ellos, que sean tales quales conbienen al serbicio de S.M., como persona que tiene esperiencia y conosce y sabe las personas que conbienen para tal ministerio y lo hará a su tienpo, que es quando se tome la lista general antes de enbarcar, como se suele y acostumbra hazer, y que pues S.M. ha mandado y manda al dicho corregidor que dexe al dicho don Antonio libremente entender en todo esto, se lo dexe hazer y le dé quando se le pida el fabor e ayuda que ubiere menester, si alguno fuere que no siente más de sólo que cunpla lo del dinero, como S.M. se lo ha mandado, y que, si desto no es contento, que el dicho corregidor haga lo que le parezca, que, como sea cosa que toque al serbicio de S.M., él está presto de serbirle y ocurrir a todo lo que le mandare de parte de S.M., para que con más brebedad se pueda hazer y haga lo que tiene mandado y a su real serbicio conbiene, y que no se ande en demandas y respuestas dilatándolo, y que, si no quiere acudir con los dichos reales al dicho don Antonio, acuda con ellos a los dueños de los nabíos que le están obligados a darles los dichos duzientos marineros, porque, si no se cunple con ellos lo que está contratado, que es darles luego todo el dinero necesario para los poder alistar, los quales dichos dueños 
de nabíos están obligados a darle los dichos duzientos marineros suficientes, y el que no fuese tal al tienpo de la lista general, antes del enbarcar se podrá escluir, y estarán obligados a dar otros en lugar de los que se deshecharen, y así lo que aora el dicho corregidor pide y requiere ni conbiene ni se puede hazer por las causas que dichas tiene, y que, si luego no le da y manda ynbiar a esta villa todo el dinero que S.M., ni se podrá cunplir ni hazer por los dueños de los dichos nabíos lo que están obligados ni se podrían apremiar a ello, pues de su parte del dicho don Antonio no se lee e cunple lo que está contratado, que pues dize que tiene en su poder el dicho dinero, le requiere las vezes que debe y es obligado, lo mande ynbiar luego aquí a esta villa de Castro para que le pueda acudir con ello a los dueños de los dichos nabíos y començar a hazer las bituallas y a lo demás que conbiene y, de no lo hazer ansí, protesta contra el dicho corregidor lo que en tal caso protestar le conbiene y de dar quenta dello a S.M para que probea lo que más conbenga a su real serbicio.

Y esto dixo que daba y dio por su respuesta y pidió a my el dicho escribano no dé al dicho corregidor ni a la parte d'él ni a otra persona alguna el dicho requerimiento sin ésta su respuesta todo debaxo de un signo, y todo ello se lo dé tanbién al dicho don Antonio signado en pública forma, en manera que haga fee, que siendo para ello nescesario requerimiento me le haze en forma a my, el presente escibano, y lo pidió por testimonio y a los presentes dello sean testigos.

Don Lope Urtado de Mendoça y y Antonio de Oyando y Diego de la Puente, vezinos y estantes en la dicha villa, y el dicho don Antonio Urtado lo firmó de su nonbre.

Don Antonio Urtado de Mendoça.

Fuy presente García de Peñabera. Ba hemendado «bos», «en», «el», bala, y testado «quede», «en», «a», «res», «quando», «conbiene» y «a él», no bala.

E yo, el sobredicho García de Peñavera, escrivano público del Rey, nuestro señor, y del número e ayuntamiento de la villa de Castro de Urdiales, presente a lo que diche es este dicho treslado hize sacar del oreginal que se entregó a Antonio de Olarte Otañes, alcaide en la dicha villa, para que le enviase a don Ordoño de Çamudio, corregidor en estas cinco fojas y una plana de papel en ésta en que va mío signo, que lo entregué de pedimiento e requerimiento de don Antonio Hurtado de Mendoça, que doy fee conocer, y en testimonio dello fize mío signo qu'es atal de verdad. García de Peñavera. Gratis.

\section{Documento 1/c}

1587/05/02. Castro Urdiales (doc. 54)

El corregidor de las Cuatro Villas contesta al requerimiento de don Antonio Hurtado de Mendoza, que le es notificado en persona, insistiendo en que el responsable del retraso en el cumplimiento de los mandatos reales era aquél.

Escrivano presente dará por testimonio signado en manera que haga fee a mí, don Ordoño de Çamudio, cuya es la casa de Çamudio, cavallero de la Horden de Sanctiago, corregidor y justicia mayor en las Quatro Villas de la costa de la mar por el Rey, nuestro señor, en como requiriendo digo a don Antonio Hurtado de Mendoça, que presente estava, y por quanto le es manifiesto S.M. le escribe por una carta que [...] que García de Arce, su capitán general de la provincia de Guypúzcoa, envarge navíos o levante marineros o haga otras cosas que el dicho García de Arce le cometiere. Y, estando él en esta dicha villa de Castro de Urdiales, en prosecución de lo que el dicho García de Arze le havía dicho para que levantase marineros, ayudando para ello a el capitán Hernando de Muñoz, que fue venido con dinero para la paga de los marineros que se levantasen, es público y notorio que el dicho don Antonio Hurtado de Mendoça rescivió a primero deste mes una carta de S.M., en que dizen que le manda aprestar quinze pinaças con marineros para servir en lo que se le mandare y que ha dicho que en las dichas pinaças les está mejor yr a los dichos marineros por las ventajas que se le darán y comodidad[es] que se les harán, por lo qual los dichos marineros se an ynclinado a yr más en las pinaças propias de su tierra que venirse a alistar en otra forma, y por tanto requiere al dicho don Antonio que huse de la comisión que tiene de S.M. y comience a tomar las pinaças y alistar la gente que conbienbe para ellas, porque, como todo se 
para su real servicio, el dicho Ordoño de Çamudio suspenderá lo que ha començado a hazer, visto que la dicha gente tenga más ánimo de yr en las dichas pinaças, que no en navío de fuera, y le ayudará a ello en lo que pudiere y le fuere pedido por el dicho don Antonio, y podrá dar licencia ante el dicho capitán Hernando de Muñoz con el dinero que para pagar la gente de mar que se quiera alistar, y que, si no tiene horden el dicho don Antonio, le dé e engañe a las tales gentes para que se vengan alistar y a rescebir las pagas de mano del dicho capitán Hernando de Muñoz, protestando de lo [...] y de todo protestando.

Don Hordoño de Çamudio.

En la villa de Castro de Urdiales, a dos días de mayo de mill e quinientos e ochenta y siete años, por ante y en presencia de mí, García de Peñavera, escrivano público y escrivano, paresció don Ordoño de Çamudio, corregidor de las Quatro Villas de la costa de la mar, e hizo el requerimiento de suso a don Antonio Hurtado de Mendoça en su persona, el qual dixo que lo oya e pedía testimonio.

Testigos, Antonio de Olarte Otañes, Jullián de Otañes y otros vecinos de la dicha villa.

García de Peñavera.

Después de lo susodicho, en la dicha villa de Castro de Urdiales, a los dichos dos días del dicho mes de mayo y del dicho año, en presencia de mí, el dicho escrivano, y testigos, paresció don Antonio Hurtado de Mendoça, vezino desta dicha villa, dando respuesta al requerimiento desta otra parte a él echo, dixo que lo que al dicho requerimiento tiene que responder es que, como el dicho don Ordoño save y es notorio por havello visto, el Rey, nuestro señor, envió a mandar al dicho don Antonio por carta firmada de su real nonbre, su fecha en tres de março, entre otras cosas que procure levantar muchos marineros de nuevo para le yr a servir a la ciudad de Lisboa, y que el dicho don Ordoño le proverá para ello de veynte mill quinientos quarenta y ocho reales, y que por no se los haver proveydo como S.M. por dicha carta lo envía a mandar, y después lo mismo por otras dos cartas de nueve [y] veynte y tres del dicho mes de março, ha dexado y dexa de tener alistado para el día de oy de trecientos marineros arriva y las vituallas para todos ellos y para los que se han recogido de los que se venieron de la dicha armada echas y los navíos para los dichos marineros por estar a punto aparejados y adereçados como conbenía y bergados para poder pasar la buelta de Lisboa, como S.M. lo a enviado a mandar, lo hiziesse y que todo se a dexado de hazer porque el dicho don Ordoño no le a dado los dichos beynte mill e quinientos y tantos reales y todo lo demás nezesario, como S.M. se lo a enviado a mandar, lo haziendo, y por dichas causas y tanbién por la que escrivió de catorze de abril, que por otra parte en la dicha carta de tres de marzo S.M. enbía a mandar al dicho don Antonio avisse si se podrán sacar desta villa y llevar a Lisboa catorze o quinze pinaças tripoladas de jente marinera por el orden que S.M. dize.

En birtud de lo qual el dicho don Antonio habló y como [...] luego con muchos dueños de las dichas pinaças sobre este particular y con otros muchos marineros muy buenos para que quisiesen yr en ellas, los quales dixeron al dicho don Antonio que holgarían de yr a servir en las dichas pinaças a S.M. y tripolar en ellas los más amigos y parientes que pudiesen, como se les diesen sus pagas, como en las ocasiones passadas. Y, bista su boluntad, escrivió a S.M. que en esta villa abrá hasta beinte pinaças y que yrían las que fuesse servido dellas a Lisboa y que escogiendo las mejores se podrían llevar tripoladas de buena jente, como dinero no faltare, y S.M. mandasse probeer dello con brebedad.

Y tanbién tuvo carta del Marqués de Santa Cruz, su fecha de 21 de febrero, en que escrivió al dicho don Antonio que si S.M. le enbiare a mandar tome algunos pataches, que los escoja que sean muy grandes veleros, fuertes y nuebos y que tengan buenas maneras en el gobernar y todo lo demás y que sean crecidos para yr con ellas, se pueda hazer buen hefecto topando cosarios. Y que así mismo, si S.M. le mandaba tomar algunas pinaças, procure que se tripolen de buenos bogadores y que en cada una bayan 20 a 22 personas y mande las dichas pinaças por el orden qu'el dicho Marqués le escrivió y que en todo esto usse de estraordinaria diligencia para que S.M. sea dello muy servido, con lo qual a ydo siempre esforçando a la gente para que baya a servir a S.M. en esta ocassión en dichos pataches e pinaças y bogándoles, que no saliesen a bogar porque con brevedad S.M. le proveerá de dinero y que ellos ganarían de comer muy más [salario] andado sirviendo a S.M. que en otra parte. 
Demás de lo qual recibió el dicho don Antonio otra carta despacho, su fecha onze de abril, en que le manda y dize, entre otras cosas, que, visto lo que le a escripto sobre lo tocante a las pinaças y pues dize que como aya dinero se podrán llevar, porque conviene para proberlo azerse luego el número de las pinaças que serán y marineros que en ellas se podrán tripolar, para que se le provea luego de todo lo nezesario, y asy tornó a hablar y esforçar más a al jente, diziéndoles cómo S.M. luego provería de dinero y que no se saliesen a navegar y aguardasen hasta ber lo que S.M. mandava, que sería con mucha brebedad.

Y que en primero de mayo rescibió el dicho don Antonio otra carta del Marqués de Santa Cruz, su fecha de diez y ocho de abrill, en que le escribe que en todo lo que le escrivió en la de beinte y uno [de] febrero no haga falta y que haga estraordinaria diligencia en todo ello, como S.M. se lo abía mandado, assí en lo de los pa[ta]ches y jente como en lo de las pinaças y que las lleve de la orden que el dicho Marqués le escrivió y que assí a tornado de hablar dello acá a los dueños de las pinaças y muchos marineros, dándoles a entender S.M. será servido en que en esta ocasión y todas las demás le sirvan como siempre lo tienen de costumbre.

Y que en los 27 del passado escrivió a S.M. cómo se lo avía mandado, avisándole de todo el diner que hera nezesario mandar probeer, assy para toda la jente que de nuevo está levantada por el dicho don Antonio y los cient marineros del capitán Johán de la Puebla, como para los ducientos marineros de los que por el dicho don Ordoño y sus ministros y el dicho don Antonio han seydo pressos de los que se venieron de las armadas, como para las doze pinaças que escrivión se podrían tomar y gente que en ellas se atripolaría, assy para el sueldo de la gente y vajeles como para las vituallas necessarias para un mes, y para que fuese con más vrevedad y S.M. lo entendiese, les partir para ello a las veynte leguas.

Y, en quanto a lo que dize el dicho don Ordoño que le es manifiesto al dicho don Antonio estar aquí en virtud de una carta de S.M., que le dirijió García de Arce, su capitán general de la provincia y alcayde de Fuenterravía, para enbargar navíos y levantar marineros y hazer otras cossas, qu'el dicho García de Arze le cometería, hasta agora a noticia del dicho don Antonio no ha venido tal cossa ni ha entendido que el dicho don Ordoño aya venido a esta villa para otro hefecto que para que él y el dicho don Antonio pongan a punto los setenta marineros que el corregidor de Vizcaya pide para los dos patajes, y que en esta conformidad partió el dicho don Antonio de sin el dicho don Ordoño de la villa de Laredo el sávado próximo veinte y cinco de abril, y que el martes depués llegó a esta villa el dicho don Ordoño y luego estuvo con él y le dixo venía a lo tractado y que despachase el correo que por su orden el dicho don Antonio havía echo detener en esta villa, y porque él havía ya escripto a S.M. por otra vía, y que después acá no le ha dicho ni dado a entender al dicho don Antonio tener la orden de S.M. y dicho García de Arze que refiere hasta esta tarde, que se lo dixo estando presentes algunas personas prencipales, vezinos desta villa e yo, el presente escribano, que dixo don Antonio, en presencia de los susodichos, tenía dicha orden, y dize que pues en executallo obrándola el hazer mucho servicio a S.M. y le estará muy vien al dicho don Ordoño el procurar que se haga todo lo que conbiene al servicio real con suma brevedad y diligencia, que es lo que en este caso se requiere, pues dize tiene escrito para ello, no le quede faltar nada que lo cumpla y [obligue] que, si el dicho don Antonio huviera tenido y el dicho don Ordoño se los huviera proveydo, como S.M. le ha mandado, ya el dicho don Antonio estuviera sirviendo a S.M. en la ciudad de Lisboa y a donde más se le ha mandado y quitado y apartado de andar en tantos requerimientos como el dicho don Ordoño le ha hecho, que se deviera de obiar porque es en deservicio de S.M., sino que cada uno acuda a lo que le está mandado, obrándolo como conbiene.

$\mathrm{Y}$ en lo que dize que hise en quanto a lo de las pinaças de la comisión que tiene y aliste la gente y si no la tiene que la debengava y dize que él ha husado y echo y haze con toda lealtad lo que por S.M. le está mandado, sin discrepar en nada y que él no haze ni engaña a nayde, ni lo ha tenido ni tiene de costumbre, ni por el presente puede hazer otra cossa de la que tiene hecha, que es conforme a lo que por S.M. se le ha mandado, como aquí tiene dicho y respondido de dicho requerimiento, salbo si don Ordoño no le probee luego del dinero para poder alistar luego la gente que tiene lebantada y socorrer a los dueños de los patajes para que los pongan a punto y hazer todas las vituallas nezesarias, como S.M. ha mandado lo haga, que en hazello así hará particular servicio a S.M., lo qual le pidí e requerí cumpla y dejándolo 
de hazer assí, protesta contra el dicho don Ordoño todo lo que en tal casso puede y debe y pidió y requirió a mí, el presente escrivano, dé al dicho don Ordoño el dicho requerimiento, sin escluir [nada], todo devajo de un sino y que assí mismo le dé un tanto de todo ello, signado del dicho don Antonio en pública forma, y que los dichos don Ordoño y capitán Fernando Muñoz no alzen la mano ni suspendan ni dejen por esto de lebantar todos los marineros que puedan, que, pues todo es para el servicio de S.M., él está presto de los favorescer y ayudar en todo lo que se le pide, lo qual hará con todo cuidado y diligencia, no faltando en nada a lo que por S.M. le está mandado.

Y esto dijo que dava y dio por su respuesta, no consintiendo en lo demás requerido y dicho por el dicho don Ordoño en este dicho y su requerimiento, y a los presentes pidió sean testigos, e lo firmó de su nonbre. Ba testado do dize «de». Después de lo qual escriovió el dicho don Antonio otra carta de S. M., su fecha el onze de abril, y no vala. Testigo, don Lope Hurtado de Mendoça [...] vezinos de la dicha villa. Don Antonio Hurtado de Mendoça. Fuy presente, García de Peñavera. Gratis.

\section{Documento 1/d}

1587/04/28. Castro Urdiales (doc. 56)

Pregón dado de orden del corregidor para que acudieran a alistarse todos los marineros de la villa que habian ido con don Antonio Hurtado de Mendoza a Lisboa para participar en la armada real y se habian vuelto a Castro.

Al día siguiente comparecen los marineros y son alistados. Finalmente, los 71 alistados son embarcados el 4 de mayo rumbo a Portugalete, de donde serían expedidos a Lisboa con don Antonio Hurtado de Mendoza.

Lista de don Ordoño de Çamudio

En la villa de Castro de Urdiales, a veynte y ocho días del mes de abril de mill y quinientos y ochenta y siete años, por ante y en presencia de mí, García de Peñavera, escrivano público del número y ayuntamiento de la dicha villa, don Ordoño de Çamudio, cuyas son las casas de Çamudio y Zugasti, Guecho y Martiarto, cavallero de la Orden de Alcántara, corregidor y justicia mayor en las Quatro Villas de la costa de la mar por el Rey, nuestro señor, dixo que él havía llegado a esta dicha villa a cosas de su servicio y procedía a hazer envarcar en los navíos que estavan en la ría y canal de neo de partida para la ciudad de Lisboa a cargo del corregidor del señorío [de Vizcaya], los marineros que en esta dicha villa estavan y que se havían venido de la dicha ciudad de los navíos que havían ydo a cargo de don Antonio Hurtado de Mendoça, vecino desta dicha villa, y porque los navíos en que havían de yr estavan para salir al primero tiempo, por tanto que mandava y mandó echar vando y pregón que todos los marineros que asy se havían venido y que havían seydo pressos por ello y dado fianças de que servirían cada que les fuesse mandado, paresciesen ante él en las casas de la governación para mañana [a] las ocho de la mañana para tomar quenta y reseñar de sus personas señales y armas y que los fiadores traygan a los que faltan dellos mesmos, parezcan so pena de que se procedería contra ellos a captura y otras mayores penas, y assy lo proveyó, mandó y firmó.

E yo, el dicho escrivano, doy fee que Luys Romero, pregonero público, a altas vozes en la plaça pública dio el dicho pregón y fue discurriendo con él por los demás lugares acostumbrados.

Don Hordoño de Çamudio. Fuy presente, García de Peñavera.

Después de lo susodicho, en la dicha villa de Castro de Urdiales, a veynte y nueve días del mes de abrilo de mill quinientos y ochenta y siete años, ante mí, el dicho escrivano, y testigos el dicho don Ordoño de Çamudio corregidor, en virtud del pregón de suso y de otro que este dicho día mandó dar, de que yo doy fee, hiço ajuntar en las casas del ayuntamiento de la dicha villa a muchos de los marineros que se havían venido de la dicha ciudad de Lisboa, a los quales les tomó la lista y reseña siguiente:

- Primeramente, passó ésta Rodrigo de Galván el moço, hijo de Sancho Galván, vecino desta villa de Castro, que estava en la çabra de Francisco Galván, su tío, moço de quinze años, robusto, sin barba. 
— Johán de Rueda, en el navío de Pero [de] Sevilla, de hedad de veynte e cinco años, corto de cuerpo, vien ajestado [asiento interlineado].

— Fortuno Díaz, vecino desta villa, en el pataje de Pero de Sevilla, de hedad de 40 años, barbinegro y le pesa corto de cuerpo.

- Martín de Quintana, vecino de Sámano, jurisdición desta villa, en la pinaça de Francisco Galván, de hedad de treynta y quatro años, buen cuerpo, barbinegro y le pesa un lobanillo en el ojo yzquierdo.

- Johán de Hoz, vecino desta villa, en la çabra de Francisco de Galván, de hedad de veynte y dos años, corto de cuerpo, barbiroxo y seco de rostro.

— Johán de Alexos, vecino desta villa, en la çabra de Francisco Galván, de hedad de treynta y cinco años, bermejo, buen cuerpo y flaco de los ojos.

- Domingo de Colunga, vecino desta villa, en la pinaça de Martín de Solórçano, perdida, de hedad de quarenta y quatro años, flaco de rostro, corto del cuerpo.

— Domingo de Allende, vecino desta villa, en la çabra de Francisco de Galván, de hedad de treynta años, seco de rostro, poca barba, largo de cuerpo.

- Antón de Lastero, vecino desta villa, en el navío de Pero de Sevilla, de hedad de veynte y cinco años, de buen cuerpo, barbiroxo, de una pierna mala.

- Domingo de Larrategui, vecino desta villa, en el navío de Pero de Sevilla, de hedad de veynte años, desbarbado, corto de cuerpo y reecho.

- Francisco de Dueñas, vecino desta villa, el de los de la provincia, fue en la nao de Johán Pérez de Amurio, de hedad de veynte y tres años, de buen cuerpo, barbiroxo [al margen: Los de la provincia].

- García de Ampuero, vecino desta villa, en las naos de la provincia, de hedad de quarenta años, buen cuerpo, barbi el pelo y roxo [al margen: provincia].

- Díez de Villegas, vecino desta villa, en la pinaça de Domingo de Somorriva, de hedad de treynta años, un poco barbado, alto de cuerpo.

— Johán de Helguera, vecino de Mioño, jurisdición desta villa, en la pinaça de Diego de La Garanda, de hedad de quarenta y seys años, de buen cuerpo, barbispeso y cano.

— Johán de la Quintana, vecino de Sámano, jurisdición desta villa, en la pinaça de Francisco Galván, de hedad de quarenta años, barbiroxo, entrecano, buen cuerpo y medrosas las piernas.

— Johán de Hormillas, natural desta villa, en el navío de Johán Gordon, de hedad de diez y ocho años, desbarbado y buen cuerpo.

- Bartholo de Palacio, vecino desta villa, en el navío e Francisco Lastero, de hedad de treynta años, corto de cuerpo, barbiroxo, vien cojestado.

- san Juan de Quartas, vecino desta villa, en el navío de Francisco Lastero, de hedad de treynta y seis años, corto de cuerpo, barbinegro y manco.

- Pero Ballibián, vecino desta villa, en el navío de Johán Gordon, de hedad de treynta años, seco de cuerpo y corto.

— Johán de la Fuente, vecino desta villa, en el navío de Antón de Carasa, de hedad de veynte y seis años, buen cuerpo, barbinegro.

- Estevan d'Escovedo, en la pinaça de Domingo Somorriva, de hedad de diez y ocho años, moço desbarbado, alto y seco, natural desta villa.

— san Juan de Enveres, vecino desta villa, en la çabra de Juan de Balmaseda, de veynte y quatro años, moço de buen cuerpo, robusto, barbiroxo.

- Pero de Udalla, vecino desta villa, en la çabra de Martín de Solórçano, perdida, de hedad de treynta años, corto de cuerpo, barbiroxo.

- Johán de Ogaña, vecino desta villa, en el navío de Sancho de Somorriva, de hedad de veynte y quatro años, moço de buen cuerpo, barbiroxo.

- Pero de Somolusa, en el navío de Sancho de Somorriva, de hedad de veynte y un años, de buen cuerpo, seco de rostro, poca barba y roxa, es vecino desta villa.

- Rodrigo Tonelado, vecino desta villa, en el navío de Martín de Solórçano, que se perdió, de hedad de veynte años, de buen cuerpo y jesto, poca barba y roxa. 
- Gonçalo de Santa Clara, vecino desta villa, en la pinaça de Diego de Sevilla, perdida, de hedad de veynte y cinco años, ympedido de la espalda.

- Rodrigo de [Santa María], vecino desta villa, en la pinaça de Domingo Somorriva, de hedad de veynte años, moço de buen cuerpo, desbarbado.

- Pero de Villanueva, vecino desta villa, en la pinaça de Juan de Valmaseda, de veynte y cinco años, poca barba y corto de cuerpo.

- Bastián de la Bárcena, vecino desta villa, en el navío de Juan de Valmaseda, de veynte y quatro años, corto de cuerpo, poca barba.

— Torivio Gómez, vecino desta villa, en el navío de Johán de Valmaseda, de veynte y seis años, de buen cuerpo y jesto, poca barba y roxa.

— Martín de Salaçar, natural desta villa, en el navió de Diego de Sevilla, perdido, de hedad de diez y ocho años, buen cuerpo y jesto.

- Juan Ramos, natural desta villa, en la çabra de Juan de Valmaseda, moço de diez y ocho años, buen cuerpo, poca barba roxa, bien ajestado.

- Tiso d'Escovedo, vecino de Mioño, jurisdición de Castro, en el navío de Pero de Sevilla, de hedad de veynte y un años, desbarbado, pecoso en el rostro y seco.

- Andrés Gómez, llamado en la lista «Laredo», en el navío de Pero de Sevilla, vecino desta villa, de hedad de veynte y tres años, buen jesto y cuerpo, poca barba y roxa.

- Johán Blanco, vecino desta villa, en el navío de Antón de Carasa, de hedad de veynte y un años, moço desbarbado, buena persona y jesto.

- Domingo Suárez, vecino desta villa, en el navío de Antón de Carasa, de veynte y dos años, de buen cuerpo, alto y barbiroxo.

- Juan de Herrera, estante en esta villa, en el navío de Francisco Galván, de hedad de veynte años, de buyen cuerpo, poco barbado y roxo.

- Johán de Colunga, vecino desta villa, en el navío de Francisco Galván, de treynta años, alto de cuerpo, seco, barbiroxo y cojea un poco.

- Bastián de la Antigua, vecino desta villa, en el navío de Francisco Lastero, de hedad de veynte y dos años, buen cuerpo, barbiroxo y poca [barba] y una señal en el rostro.

- Martín de Alday, vecino de Otañes, jurisdición desta villa, en el navío de Johán Gordon, de hedad de treynta años, honbre corto, flaco de rostro, barbiroxo.

- Sancho Barba, vecino desta villa, en el navío de Pero de Sevilla, de hedad de veynte y ocho años, buen cuerpo, barbinegro, seco de rostro.

- Francisco de Montellano, vecino desta villa, en el navío de Domingo de Somarriva, de hedad de veynte y dos años, poco más o menos, de buen cuerpo, alto talle y jesto, poca barba y roxa y un dedo de menos.

- Gonçalo de Carasa, vecino desta villa, en el navío de Diego de Carasa, de hedad de veynte y quatro años, corto de cuerpo, poca barba en el carrillo y nada por los lados.

- Antón de Rasines, vecino desta villa, en el navío de Francisco de Galván, de hedad de veynte y dos años, moço de buen cuerpo, alto, robusto, barba roxa.

- Antón de Xijón, vecino desta villa, fue en la Almiranta de Guypuzcua, de hedad de treynta años, barba negra, corto de cuerpo [al margen: provincia].

- Antón de Montellano, vecino de Lusa, en la çabra de Alonso de Lastero, de hedad de veynte y seis años, seco de rostro, barba roxa.

- Johán de Prado, vecino de Otañes, en el navío de Johán Galván, de hedad de veynte y dos años, moço de buen cuerpo, corto y roxo.

- Pero de Gana, natural desta villa, en el navío de Juan Gordon, de hedad de veynte años, buen cuerpo y desbarbado [al margen: de don Antonio].

- san Juan de Llantada, vecino de Santullán, en el navío de Alonso de Lastero, de hedad de veynte y nueve años, buen cuerpo, seco de rostro, mal barbado por los lados.

- Pero Ximeno, vecino desta villa, en el navío de Johán de Balmaseda, de hedad de cinquenta años, corto de cuerpo, speso de barba, moreno. 
- Juan de Llantada, vecino desta villa, en el navío de Juan de Sant Martín Garbijos, de hedad de treynta años, buen cuerpo, barbanegra [al margen: ojo].

- Juan de Dios, vecino de Sámano, en la pinaça de Juan de Valmaseda, de hedad de quarenta años, corto de cuerpo y un poco lesiado de la pierna.

- Lope de Quartas, hijo de Juan de Quartas, natural desta villa, de hedad de honze años, mochacho moreno, en el navío de Francisco Lastero [al margen: buen soldado].

La qual dicha reseña se tomó en mi presencia, de que doy fee. Fuy presente, García de Peñavera.

- En dicho día Francisco Vélez, natural de Valle de Guriezo, en la pinaça de Johán de Valmaseda, de hedad de veynte años, buen cuerpo, desbarbado.

García de Peñavera.

— En treynta de abril de dicho año paresció Sancho de Obares, vecino de Hontón, como fiador de Juan de Quintana para le traer y servir, y havía ydo con Pero [de] Sevilla [al margen: ojo].

- Martín de Quintana, natural de Hontón, jurisdición desta villa, en el navío de Pero de Sevilla, moço de hedad de diez y ocho años, alto, desbarbado y suto de cuerpo [al margen: ojo].

- En treynta de abril de quinientos ochenta y siete fue en el navío de Johán de Sant Martín, Domingo Otero, vecino de Placencia, de hedad de veynte y tres años, buen cuerpo, desbarbado y vien ajestado.

- Dicho día Martín de la Andayda, vecino de Armença, en Vizcaia, fue en el navío de Pero Garbijos de Puerto, de hedad de quarenta años, corto de cuerpo, espeso de barba castanica.

- Dicho [día] Pero de Udía, vecino de Loxen, en Vizcaia, fue en el navío de Antón de Carasa, de hedad de veynte y cinco años, señalado en la frente y en el lado yzquierdo en la sien.

— Johán de Prado, vecino de Otañes, jurisdición desta villa de Castro.

- Juan de Arze, vecino del Valle de Sámano, jurisdición de la villa de Castro, en el navío de Johán de San Martín, de hedad de veynte y dos años, alto de cuerpo, poca barba y moreno.

- En dicho día Pero Gómez de Hinojedo, natural de Ynojedo, cava Sant Martín de la Arena, en la çabra de Francisco de Galván, de hedad de veynte y quatro años, buen cuerpo, poca barba, moreno, no tenía sino un po[co] de vigote.

- En dicho día Juan Guitar, vecino desta villa, en el navío de Juan de Valmaseda, de hedad de treynta años, corto de cuerpo, roxo, en la cabeça una señal como de tiña.

— En primero de mayo de quinientos y ochenta y siete, Johán del Hoyo, vecino de Colindres, estava en el navío de Johán de Sant Martín Garbijos, de hedad de treynta años, buen cuerpoi y talle, varbaroxa.

— En dicho día, Johán de Albehar, vecino de Colindres, en el mesmo navío de Johán de Sant Martín, de hedad de veynte y seis años, un poco de bigote, bien ajestado y cuerpo.

- En dos de mayo de quinientos y ochenta y siete, Francisco del Corro, vecino de la villa de Laredo, en el navío de Johán de Sant Martín, de hedad de veynte y cinco años, buen cuerpo, jesto y talle.

- Dicho día, Gregorio de Bedia, vecino de la villa de Laredo, en el navío maestre Alonso de Lastero, vecino desta villa, de hedad de quarenta años, corto de cuerpo, robusto, la boz un poco ronca.

- En dicho día, Llorente de Galiciano, vecino de la villa de Laredo, en el navío de Francisco de Lastero, alto de cuerpo, de veynte y quatro años, un poco vizco de los ojos.

- En dicho día, Phelipe d'Escalante, vecino de la villa de Laredo, en el navío de Johán de Sant Martín, de hedad de veynte años, un poco de loco, patituerto y corto.

- En tres de mayo de quinientos y ochenta y siete se alistó Juan Díaz de Villegas, vecino de la villa de Laredo, havía ydo en la çabra de Diego de la Gándara, de hedad de diez y nueve años, alto de cuerpo, vuen talle y desbarbado.

- Pero de la Serna, vecino de Colindres, en el navío de Johán de Sant Martín, de hedad de veynte y dos años, buen cuerpo y talle, moreno.

- Francisco de Layseca, vecino de Mioño, en la çabra de Juan de Valmaseda, de hedad de veynte y quatro años, buen cuerpo y desbarbado, moreno.

- Juan de Arze, vecdino desta villa, en el navío de Juan de Sant Martín, de hedad de veynte y quatro años, poca barba, moreno, buen talle. 
- Juan de Marrón, natural de Marrón, junto de Laredo, moço de hedad de veynte años, corto, robusto, moreno y desbarbado.

- Johán de Liendo, vecino de Laredo, de edad de veynte y seys años, corto de cuerpo, barba roja.

- Bastián Fierro, vecino de Laredo, en 4 de mayo, en la pinaça de Diego de Carasa, de hedad diez y nueve años, bien ajestado y sin barba.

— En dicho día, Pero de Francos, vecino de Laredo, en el navío de Johán Gordon, de veynte y dos años, robusto y moreno.

Va entre renglones en esta lista o dize «Sant Juan de Rueda, en el navío de Pero de Sevilla, de hedad de veynte y cinco años, corto de cuerpo, vien ajestado y robusto», valga, y testado «Johán de Guitar, vecino desta villa» y una partida de tres renglones, que comiença «Johán de Arze» y acava «buen talle», no valga.

1587/05/04. Muelle de Castro Urdiales

Entrego de marineros

Después de lo susodicho, en la villa de Castro de Urdiales y a la punta del muelle de la dicha villa, a quatro días del mes de mayo de mill e quinientos y ochenta y siete años, por presencia de mí, García de Peñavera, scrivano público, y testigos, estando enbarcados todos los marineros contenidos en la lista de atrás, excepto los ojeados en la margen, que no pudieron ser havidos, y don Antonio Hurtado de Mendoça, vezino de la dicha villa, dentro de la dicha pinaça que les llevava a la villa de Portugalete a los entregar al corregidor de Vizcaia, en nonbre del Rey, nuestro señor, y delante de muchas personas que a la mira estavan, don Ordoño de Çamudio, corregidor de las Quatro Villas, pidió por testimonio a mí, el dicho escrivano, de cómo él, en nonbre del Rey, nuestro señor, entregava setenta y un marineros, que estavan metidos en la dicha pinaça, que heran los contenidos en la dicha lista, menos los ojeteados, para que el susodicho los lleve a la dicha villa de Portugalete, a donde le estava sperando el Licenciado Duarte de Acuña, corregidor del señorío de Vizcaia, para los envarcar en dos navíos que allí estavan prestos para la ciudad de Lisboa, y el dicho don Antonio Hurtado de Mendoça los tornó a numerar y pasar uno a uno por la lista y parescieron el número de los dichos setenta y uno, y el susodicho don Antonio se dio por entregado de ellos, y movieron para la dicha villa de Portugalete. De [...] de todo ello yo, el dicho scrivano, doy fee por me haver allado a ello presente y es[tuvieron] por testigos, don Johán de Otañes, el capitán [Hernando] de Muñoz, vezino de San Sebastián, y el capitán Puebla, [vecino de] Santander, don Antonio de Arze, vezino de Guriezo, prior de [...], el Licenciado Rasines vicario y otras m[uchas] personas, vecinos de la dicha villa, y de todo doy fee. García de Peñavera.

\section{Documento 2}

\section{7/04/23. San Sebastián}

García de Arce Cabeza de Vaca, capitán general de Guipúzcoa, ordena al capitán Fernando de Muñoz reclute marineros par la armada de 5.000 o 6.000 toneladas ordenada hacer por el Rey, la cual estaba en Pasajes.

Siguen autos en Castro.

AHPC, prot. 1.697 (1587), doc. 73.

Lista del capitán Hernando Muñoz

García de Harze Caveça de Baca, capitán general desta probincia de Guipúzcoa por el Rey, nuestro señor, y su alcayde de la villa de Fuenterravía, por quanto S.M. me ha mandado que en esta provincia en el puerto del Pasaje junte e ponga en horden con mucha brevedad una harmada de cinco o seis mill toneladas para efectos ynportantes a su servicio, e por no haver en la dicha provincia e lugares de su costa el número y cantidad de gente de mar que conbiene para tripolar las naves, es nescesario lebantar la más della en el Señorío de Bizcaya e Quatro Villas de la costa de la mar, y por conbenir que para este 
efecto aya persona de espiriencia y plático, concurriendo éstas en bos, el capitán Fernando de Muñoz, por la presente hos he querido nombrar y hos nonbro para que desde el día de la fecha desta comisión, la qual se hos entregará, bayáis al Señorío de Bizcaya y Quatro Villas de la costa de la mar y dando a los corregidores de ellas las cartas de S.M. e mías que para ellos llebáis, ayáis de entender y entendáis en lebantar y alistar la dicha gente de mar que sea útil y de servicio y pláticos en la navegación, dándoles las cinco pagas que S.M. manda, y que la gente que se conduciere y listare sea abonada para que sea seguro el dinero que se les diere, los quales dichos marineros se alisten ante las justicias de la villa o lugar donde se listaren, declarando la bezindad cada uno dellos de donde son vezinos, e que la tal justicia apruebe y abone su bezindad de donde es bezino y que el scrivano dé fee dello y del dinero que se le diere al que ansí se listare, el qual dicho dinero se entregará delante de la justicia e con ynterbención suya, allándose presente el dicho capitán Fernando de Muñoz, en presencia del escrivano, de lo qual dará fee, obligando a los que así se listaren que sirbirán a S.M. en la presente harmada sin hazer falta ninguna y acudirán a ella quando se les mandare así enbarcar, pidiendo para todo lo susodicho favor y ayuda a los dichos corregidores y justicias, para que hos le den, a los quales, de parte de S.M., pido que ansí lo hagan, pues cunple tanto a su servicio, que para todo ello y lo dello anexo y dependiente bos doy poder y comisión en forma, en virtud de la que yo he e tengo de S.M. Fecho en San Sebastián, a veinte e tres días del mes de abril de mill y quinientos y ochenta y siete años, García de Arce. Por mandado de García de Harze, Martín Pérez de Huarte.

Hecho, sacado, corregido y concertado fue este dicho treslado del original, que se entregó a la parte por mí, García de Peñavera, escrivano del Rey, nuestro señor, y del número de la villa de Castro de Urdiales. Fue fecha en ella a quatro días del mes de mayo de mill y quinientos y ochenta y siete años. Y en testimonio dello fize mi sygno qu'es atal de verdad. García de Peñavera.

E luego, yn continente, a los dichos quatro días del mes de mayo y del dicho año de mill y quinientos y ochenta y siete años, en presencia de mí, García de Peñavera, escrivano público, y husando de la comisión de suso, el capitán Fernando de Muñoz, vecino de la villa de Sant Sebastián, estante en esta dicha villa, con yntervención de don Ordoño de Çamudio, corregidor de las Quatro Villas, començó a tomar lista de alguna gente marinera que se quisiere asentar por las villas y lugares en la dicha comisión contenidas, la qual dicha lista el susodicho tomó y es a hazer en la forma y manera siguiente:

- en quatro de mayo de mill quinientos y ochenta y siete ante don Ordoño de Çamudio, corregidor destas Quatro Villas, y por presencia de mí, García de Peñavera, scrivano público del número de la dicha villa, se havía listado para servir en la armada que se junta en la villa de Sant Sebastián, del cargo de García de Arze, capitán general de la provincia, Francisco del Tojo, vecino del lugar de San Martín de Hontón, jurisdición de la dicha villa de Castro, hombre alto de cuerpo y marinero suficiente, de hedad de cinquenta y cinco años, pocos más o menos, cano y vien dispuesto; recivió del capitán Hernando de Muñoz, en nonbre del dicho García de Arce, quinze ducados en horo, de que yo, el dicho escrivano, doy fee por haverme allado a la dicha paga.

Corre el sueldo desde oy día del asiento adelante.

- en dicho día, mes y año de suso se alistó por orden del dicho capitán Hernando de Muñoz, delante del dicho don Ordoño de Çamudio, para servir en las ocasiones al thenor y forma de la comisión en caveça desta lista prelenotada, Martín de Martiarto, vecino de Guecho, moço de veynte y dos años, de buen talle, roxo, seco de rostro, un poco de mostacho, y le fio Rodrigo de Luyçaga, vecino desta villa, que se obligó a que serviría o que bolverá el sueldo que rescive, que fueron quinze ducados en reales, que montan cinco pagas, de la qual paga y rescivo yo, el dicho scrivano, doy fee hiço el dicho Hernando Muñoz.

Rodrigo de Luyçiga [firma tosca].

— en dicho día se alistó por marinero con el dicho Hernando de Muñoz, digo, en cinco de mayo de quinientos y ochenta y siete, Lucas de Arreguyti, vecino de Nuestra Señora de Arandio, en Vizcaya, de hedad de treynta años, corto de cuerpo, el cavello roxo y la barba, obligose de serbir a donde se le mandare por el dicho capitán Hernando de Muñoz, y le acreditó de que serviría Diego de Jáurigui galafate, 
vecino desta dicha villa, rescivió cinco pagas de contado por presencia de mí, el dicho scrivano, de que doy fee havérsele dado y pagado el dicho capitán Hernando de Muñoz, y el dicho Diego de Jáurigui se offresció que el susodicho serviría y en defecto de no lo hazer, que él bolvería el dinero luego y como mrs. y haver, y por no [saber] firmar rogó a Juan de Maricheaga lo firmase por él.

[al margen:] en 5 de mayo 1587.

Obligose Johán de Marecheaga por el dicho Domingo de Jáurigui a que servirá las cinco pagas que ha rescebido el dicho Lucas de Arreguyti, a tres ducados por mes, y en defecto que dará otra persona tam suficiente como el alistada o servirá él con la suya, y lo firmó el dicho Maricheaga.

Por testigo, Johán de Marecheaga.

- en dicho día cinco de mayo de quinientos y ochenta y siete, ante don Ordoño de Çamudio corregidor y el capitán Hernando de Muñoz, por mi presencia, se alistó para servir en esta ocasión Juan de Aresti, natural del puerto de Asua, de hedad de quarenta y seis años, corto de cuerpo, medio cano, rescivión del dicho capitán cinco pagas de contado, a tres ducados por mes, de que yo, el dicho scrivano, doy fee; aprovole el dicho corregidor y se obligó de servir cada que se le mande.

Juan de Arexti. [al margen:] Don Ordoño de Çamudio.

- en dicho día cinco de mayo del dicho año se alistó con el dicho Hernando de Muñoz y por asistencia del dicho don Ordoño de Çamudio corregidor, que le acreditó, Sancho de Asua, hijo de Johán de Asua, natural del puerto de Asua, de hedad de veynte y un años, y se alistó por marinero, moço alto, de buen rostro y desbarbado, recivió de contado del dicho capitán y por mi presencia, de que doy fee, cinco pagas a tres ducados por cada una en horo.

Córrele el sueldo a todos desde el día de la lista a éste y a los demás listados y que se listaren.

Firmó por el Gregorio de Otañes, vecino de Otañes.

Gregorio de Otañes

Don Ordoño de Çamudio.

\section{Documento 3}

1590/06/06. Santander

Don Luis Fajardo, corregidor de las Cuatro Villas, luego de insertar cédula real, de 8 de abril, dándole instrucciones para la creación de cabos de mar, que manden a los vecinos para que se ejerciten en la guerra, nombra cabo de la Junta de Sámano a Gregorio de Otañes, especificando sus atribuciones.

AHPC, prot. 1.697 (1590), doc. 59. ${ }^{153}$

Don Luys Faxardo, cavallero del ávito de Calatrava, corregidor y justicia mayor de las Quatro Villas de la costa de la mar, a cuyo cargo están las cossas tocantes a la guerra dellas y sus districtos por el Rey, nuestro señor, etc., por quanto me mandó escrevir una su real carta, del thenor siguiente:

\section{[1590/04/08. Madrid]}

El Rey

Don Luys Faxardo, mi corregidor de las Quatro Villas de la costa de la mar, aunque en la que os escreví a los diez y seys del pasado sobre la orden que havéis de dar para que se exerciten los naturales de los lugares de vuestros districtos en las armadas y acudan a la defensa de la costa de la mar se dize que an de tener cavos que los goviernen, no se declaró quién los ha de nombrar y porque parece lo más conveniente que vos los nombréys, porque estoy muy confiado que serán los más pláticos soldados y más acreditados que oviere entre ellos mismos, os encargo y mando que assy lo ordenéys y nombréys luego para que no se pierda tiempo en la execución, y acusarmeys de los que nombrásedes, para que yo lo tenga entendido, y advertid que los tales cavos han de obedecer a los sargentos mayores.

${ }^{153}$ Más adelante piden que no haya cabos, sino que se siga con la antigua costumbre de que, en caso de guerra, fueran general, alférez y sargento, respectivamente, el alcalde mayor, un regidor y el procurador general, pues con el sistema nuevo se habían producido inconvenientes. 
De Madrid, a ocho de abril de mill e quinientos y noventa años.

Yo el Rey. Por mandado del Rey, nuestro señor, Andrés de Prada.

Y en cumplimiento de la dicha cédula real suso yncorporada, haviéndome ynformado de la persona de Gregorio de Otañes, vecino del Valle de Otañes, y constándome que es tal persona benemérita y plático en las cosas de la milicia y buena diciplina della, y que concurren en él las demás calidades necesarias, mi boluntad es de le nombrar, como por la presente le nombro, por cavo de toda la parte que al presente ay y en adelante huviere en la Junta de Sámano y su districto y vezinos d'él, y como tal pueda nombrar en ella officiales como son alférez, sargento y cavos d'esquadra para que junten la dicha gente, y mando que para ello tenga bandera y caxas y se le entregue la que ay en la dicha Junta para que la dé al alférez que nombrare, y mando a los cavalleros, scuderos e hijosdalgo de la dicha Junta de Sámano le ayan y tengan por tal y le obedezcan y onren y acaten y acudan a sus llamamientos y hagan guardar todas las preheminencias, libertades y esenciones y todas las [cosas] que por raçón a el dicho officio le pertenezcan, al qual dicho Gregorio de Otañes mando que en las ocasiones que se ofrecieren del servicio de S.M. acuda con su persona y gente a la parte que por mí se le ordenare con mucha puntualidad, como d'él confío, y en los alardes y exercicio de la gente de la dicha Junta de Sámano salga con los vecinos della que an do el tal oficio obedesciendo en ello a Diego de Velasco, el sargento mayor deste mi districto, como S.M. lo manda, y no haviendo orden particular o de quién en nombre de S.M. se la pueda dar, la tendrá de acudir en qualquier revato a el socorro desta villa de Santander, sin aguardar otro aviso, más de entender que vienen henemigos sobre la dicha villa, o que sea tocado a el dicho revato en ella o en otra desta costa, y para esto se dará orden que los barcos de los pasajes estén muy a punto y aprestados para pasar la dicha gente, y ninguno de los dichos vezinos de la dicha Junta e avitantes en ella vayan contra esto ni desobedezcan ni desacaten al dicho Gregorio de Otañes, so las penas en que caen e yncuyrren los soldados que en los exércitos no obedecen a sus capitanes y officiales, contra los quales hará ynformación y me la enviará para que yo provea en ello lo que convenga al servicio de S.M., que para todo ello le hago este dicho nombramiento, tan cumplido y bastante como yo le tengo de S. M., y mando se publique y que García de Peñavera, scrivano de armadas, lo autorice, de lo qual mandé dar la presente firmada de mi nombre y sellada con mi sello y refrendada de mi secretario, en Santander, a seys días del mes de junio de mill quinientos y noventa años.

Don Luys Faxardo. Por s.m., Pero de Bargas Salaçar.

Es el tanto corregido y concertado y está de mí autoriçado. [Firma ilegible: ha de ser 'García de Peñavera'].

\section{APÉNDICE II}

1594/10/29. Bruselas (ducado de Brabante)

El Dr. Fernando de Salinas, comisario general de la armada de los Países Bajos, certifica cómo en 1590 los capitanes Juan de Castilla y Baltasar de Ortigosa, junto con el teniente Bernardino Cossío, habian armado una galeota en el puerto de Nieuport, con licencia del duque de Parma, para practicar el corso contra el enemigo; que en el curso de sus acciones prendieron un buque inglés, que transportaba al general William Winter, embajador de la Reina ante el príncipe de Bearn; tras varios avatares, Winter estuvo retenido en Amberes hasta febrero de 1593, en que fue canjeado por don Pedro de Valdés; Winter pagó su rescate, pero Valdés no, habiendo prometido abonar 10.000 escudos a dichos corsarios.

Archivo Histórico Nacional, Órdenes Militares, Archivo Histórico de Toledo, expte. 5.563 (Proceso seguido hasta 1609 por Bernardino Cossío contra don Pedro de Valdés, comendador de Oreja. Parece que hay sentencia condenatoria contra Valdés; en mal estado).

Certificado:

Yo, el doctor Fernando de Salinas, del consejo privado del Rey, nuestro señor, y commisario general de su armada nabal en estos sus Estados Baxos, certifico y doy fee verdadera a todos los que la presente vieren ser verdad que, haviendo los capitanes Juan de Castilla y Baltasar de Hortigosa y el teniente Ber- 
nardino Cossío en el año de mill quinientos y nobenta, con licencia y commissión del señor duque de Parma y Plasencia, que Dios aya, por entonces lugarteniente governador y capitán general por S.M. en dichos sus Estados, armado una galeota en el puerto de Nioporte, en el condado de Flandres, para con ella hazer la guerra a los rebeldes y enemigos de S.M., acertaron, tras diversos viages y salidas que dicha galeota avía hecho, a tomar en la costa de Yngalaterra un vajel passajero ynglez, en que yba un cavallero llamado Winter, enviado por su Reyna en embaxada al príncipe de Bearn, y por faltalles el viento fueron forçados tomar puerto en Francia, donde, con consentimiento del duque de Umena, dicho su prisionero fue entregado al marquez de Renty, que Dios aya, por entonces admirante de la mar en estos dichos Estados, que con buena guardia y a su costa lo embió a ellos, a requisición de dichos tomadores, donde por mayor seguridad dellos y de dicho admirante fue por orden del dicho duque de Parma embiado y guardado en el castillo de Anberes asta el mes de hebrero del año de mill y quinientos y noventa y tres, que por orden del señor conde de Mansfeld fue puesto en libertad en cambio y trueque de la persona de don Pedro de Baldez, preso en dicho Reyno de Yngalaterra, donde dicho Winter antes de su partida declaró aver dado satisfación de su rescate a los tomadores de dicho don Pedro de Valdez, mediante la qual fue puesto en libertad y al mismo tiempo dicho don Pedro fue encaminado a estos Estados, que de pocos días a esta parte se ha partido de aquí para España, sin aver dado alguna satisfación o equivalencia a los herederos del dicho marquez admirante difunto, de lo que se le devía por su dinero desembolsado y décima ny a los dichos armadores de la galeota por el rescate del dicho Winter, su prisionero, que pretenden averles hecho y prometido diez mill escudos [de allá], siendo uso y costumbre generalmente observada mientras esta guerra a durado en estos Estados que el amigo rescatado en cambio de algún enemigo paga a los tomadores la equivalencia del rescate prometido por el dicho enemigo, y por ser ansí verdad, a requerimiento y instancia del conde de Sore, al presente al marido de la marqueza viuda que fue del dicho admirante y de los demás interessados, les dy la presente firmada de mi nombre y sellada del sello de mis armas. Fecha en la villa de Bruxellas, ducado de Brabante, a veinte y nuebe de ottubre de mill quinientos noventa y quatro años. Salinas [sello de placa].

\section{APÉNDICE III}

Relación de documentos sobre incidencias de marineros alistados (1590-1617)

\section{0/01/27. Castro Urdiales}

Ochoa de la Torre, Juan de Úbeda y Juan de Ormaechea, vecinos de Lejona (señorío de Vizcaya), calafates, estantes en Castro, dicen que el capitán Ginés Jiménez, vecino de Úbeda, que por orden del señor Bernabé de Pedroso, proveedor general de la armada y ejército, había venido a Castro y al Señorío de Vizcaya a proveer de calafates la armada que estaba en El Ferrol, les había mandado comparecer allá, dándoles para el camino 100 reales a cada uno.

Se obligan a comparecer en El Ferrol dentro de 20 días, so pena de 50.000 mrs. para los gastos de la proveeduría de la armada cada uno, más 5 años de galeras al remo.

AHPC, prot. 1.697 (1590), doc. 10.

\section{0/03/17. Castro Urdiales}

El capitán Diego de Portillo, alcalde de Castro, conocedor de que Alonso Ruiz mimbrero, preso en la cárcel por orden de Luis de Padilla, como soldado que había de ir a El Ferrol; sabiendo por personas religiosas que el soldado estaba en mal estado, le manda un médico.

Éste certifica su mala salud y calentura, que no podría sanar en la cárcel.

El alcalde, a pesar de que era forastero y nadie le podía fiar, ordena ponerle en casa de la viuda de M. de Nanclares para que lo curase.

AHPC, prot. 1.697 (1590), doc. 25.

\section{0/03/22. Castro Urdiales}

San Juan de Carasa, vecino de Castro, dice que la justicia quería prender a Pedro de Aguirre, vecino también, por haberse quedado sin servir en la armada real, estando alistado en ella, y, como su nave era 
una de las que estaban en la ría de Bilbao, a sueldo del Rey, y necesitaba los sevicios de Aguirre como marinero, se obliga, por indicación de la justicia, a llevarle en el viaje ordenado a El Ferrol y allí entregarlo a don Alonso de Bazán para que le ponga en el navío que ha andado.

AHPC, prot. 1.697 (1590), doc. 33.

\section{0/04/20. Castro Urdiales}

Bastián de San Juan Herrermenten, vecino de Castro, dice que Pedro de Liendo, vecino también, había tomado para el servicio real a Pedro Ortega, vecino de Arcentales, que se había alistado en su lugar hoy, recibiendo sueldo de 30 ducados (20 del Rey y 10 suyos), obligándose Liendo a que Ortega serviría sin ausentarse. Así se obliga.

AHPC, prot. 1.697 (1590), doc. 34

\section{0/04/20. Castro Urdiales}

Martín del Tojo y Antón Treto, vecinos de Castro, presos en la cárcel hasta que dieren una persona marinero y suficiente para haver de yr a servir a S.M. en la ocasión que de presente tracta, según y de la manera que le havían dado los demás maestres de chalupas de la dicha villa, para salir y estar en víspera de Pascua de Resurrección, se obligan a traer en 3 días un marinero suficiente, de lo contrario ellos mismos volverían a la cárcel.

AHPC, prot. 1.697 (1590), doc. 35

\section{0/04/20. Castro Urdiales}

Juan de Alcedo y Magdalena de Guelda, vecinos de Isla, por cuanto Juan se había alistado para servir al Rey en los galeones nuevos, dándole 20 ducados más otros 6 después, y como Juan de Terreros, vecino de Isla, le había fiado de que serviría sin ausentarse, para su resguardo, ambos se obligan a ello.

AHPC, prot. 1.697 (1590), doc. 39.

\section{0/05/02. Castro Urdiales}

Pedro de Herrado, vecino de Castro, dice que Juan de la Maza, también vecino y morador en Campillo, estaba preso para que fuese a servir al Rey por ser marinero, y el dicho Juan de la Maça decía no lo ser ni haver entrado en la mar en toda su vida; se le había ordenado que diese fianzas de que, si se probase haber entrado en la mar, serviría.

Pedro sale por fiador de que, constando Juan ser marinero, serviría.

AHPC, prot. 1.697 (1590), doc. 44.

\section{0/05/04. Castro Urdiales}

Sancho de Santibáñez, vecino del Valle de Sámano, preso en la cárcel por tocarle servir como marinero y decir no serlo.

Francisco de Mioño, vecino del mismo Valle, da fianzas de que, de serlo, servirá.

AHPC, prot. 1.697 (1590), doc. 45.

\section{0/05/04. Castro Urdiales}

Diego del Cerrillo, vecino del Valle de Sámano, por cuanto la justicia había soltado de la cárcel a Francisco del Portillo, porque no era marinero, para ir en la armada real, se constituye en fiador por si se demostrase que sí era marinero.

AHPC, prot. 1.697 (1590), doc. 55.

\section{0/05/07. Castro Urdiales}

Diego Marroquín de Mioño se obliga a traer a la cárcel, de donde le saca, a Juan Carnero, vecino de Lusa, preso para ir a la armada real, el qual, por no ser pobre y tener muchos hijos y su lugar haver echo lo que devía en la ocasión pasada, se sobrelleva, y para quando otro se mande él le bolverá a la dicha cárcel ... [se refiere a que el pueblo ya había sufrido bastante durante la Jornada de Inglaterra].

AHPC, prot. 1.697 (1590), doc. 48. 
1590/05/08. Castro Urdiales

Diego de Carranza, vecino de Castro, por cuanto a su ruego Martín Sáenz de Villanueva, también vecino, había salido por fiador de Domingo de Carranza, natural del Valle de Sámano, de que serviría en la armada real sin ausentarse, Diego también se obliga.

AHPC, prot. 1.697 (1590), doc. 47.

\section{0/05/18. Castro Urdiales}

Juan de Pando del Río, vecino de Castro, fiador de Domingo de Ochoa, vecino del Valle de Sámano, enfermo, en tanto se buscaba sustituto.

AHPC, prot. 1.697 (1590), doc. 56.

\section{0/07/22. Castro Urdiales}

Tomás de Pando y Bartolo de la Calle, vecinos de Cerdigo, se obligan a buscar entre ambos una persona que sirva en la armada real, si para ello fueren requeridos, y, si no lo hallaren, que uno dará al otro 10 ducados, como sobresueldo.

AHPC, prot. 1.697 (1590), doc. 67.

\section{0/08/03. El Ferrol}

Fe y salvoconducto, por no tener plaza, a Pedro de Somarriba, vecino de Castro, maestre de la zabra San Andrés, en lugar de Domingo de Somarriba. Se expresan los efectos pasados por Domingo a Pedro.

AHPC, prot. 1.697 (1590), doc. 80.

\section{0/08/09 y 15. El Ferrol}

Fe y pasaporte del general don Alonso de Bazán a favor de Julián de Villar Otañes, vecino de Santullán, piloto de la zabra La Trinidad, de que no tenía plaza en la armada y orden a las guardas para que le dejen pasar.

AHPC, prot. 1.704 (1607), fol. 280r.

\section{0/08/10 y 12. El Ferrol}

Don Alonso de Bazán da fe y salvoconducto al marinero Pedro de Vitoria, por no tener asentada plaza en la armada.

AHPC, prot. 1.698 (1591), doc. 7.

\section{1/05/21. Castro Urdiales}

Diego de la Quintana tundidor y Pedro de la Quintana, vecinos de Castro, por cuanto Pedro estaba preso para ir a servir al Rey en los galeones nuevos y estaba enfermo de gota, se obligan a buscar quien vaya a servir en su lugar.

AHPC, prot. 1.698 (1591), doc. 23.

\section{2/01/04. Laredo}

Don Luis Fajardo, corregidor de las Cuatro Villas, por cuanto Diego Marroquín de Mioño, vecino del Valle de Sámano, protestó de no estar comprendido entre los reos de haberse vuelto de las jornadas de Portugal, El Ferrol y Aragón, por cuanto él había salido del ejército con las licencias pertinentes tras servir en las jornadas de Vitigudino, Hinojosa [de Duero, ambos en Salamanca] y Raya de Portugal, le impone que preste fianzas, que constituye en Castro Urdiales el 13 de enero.

AHPC, prot. 1.698 (1592), doc. 2.

\section{2/02/01. Castro Urdiales}

Juan de Larrea, vecino de Santullán, y Juan de Begoña, vecino de Castro, se obligan por Mateo de Larrea, vecino de Santullán, preso por se haver venido del servicio del Rey.

AHPC, prot. 1.698 (1592), doc. 6. 
1592/02/05. Castro Urdiales

Juan de Giraldo y san Juan de Aparicio, vecinos de Castro, se obligan por Juan Ramos de Giraldo, vecino también, por haberse venido de la armada real y esquadra del general Domingo de Cibiaur.

AHPC, prot. 1.698 (1592), doc. 7.

\section{2/02/17. Castro Urdiales}

Pedro de Helguera Resmanero fía a Lucas de Velasco, vecino de Mioño, por haberse vuelto de la armada.

AHPC, prot. 1.698 (1592), doc. 16.

1592/02/22. Castro Urdiales

Miguel de Lerín, vecino del lugar de Lusa, padre de Pedro de Lerín, alistado por marinero en la armada real, que se había salido de la armada en Santander y vuelto a Lusa, ofrece fianza carcelera.

AHPC, prot. 1.698 (1592), doc. 15.

\section{5/01/15. Castro Urdiales}

Fianzas prestadas por los sujetos que se habían vuelto de la armada sin licencia:

- Juan de Perea, marinero, vecino de Castro.

- Jerónimo de Olivares, marinero, natural de Castro.

- Martín de Altamira, marinero, morador en Castro.

- Juan Gutiérrez, criado de Juana de las Cuevas, viuda de Juan Gordon, marinero, vecino de Castro, que se había venido de Lisboa.

AHPC, prot. 1.700 (1595), doc. 5.

- el día 28, Toribio de Camus, vecino de Castro (doc. 58).

\section{6/04/30. Castro Urdiales}

Ochoa de Salazar, señor de las casas de Salazar, requiere a Agustín de Lizarza, juez ejecutor de la contaduría de cuentas de las armadas reales en las Cuatro Villas, Señorío de Vizcaya y Provincia de Guipúzcoa, con sede en San Sebastián, que le había ejecutado por varios marineros que se habían fugado del servicio real.

Pide que no se proceda contra él, sino contra los interesados, que eran de las Encartaciones.

Sin, embargo, se obliga a pagar a los comisarios reales 336 mrs., por buena obra que le habían hecho.

AHPC, prot. 1.700 (1596), doc. 43.

\section{6/11/15. Castro Urdiales}

Sancho de la Hoz, vecino del Valle de Sámano, otorga fianza de no ausentarse, pues se había alistado con el capitán Diego de Pando, que iba camino del puerto de El Ferrol.

AHPC, prot. 1.700 (1596), doc. 143.

\section{9/04/13. Castro Urdiales}

Miguel de Laredo, vecino de Castro, alistado en el galeón del capitán Julián de la Sierra, que había recibido 24 ducados a cuenta de sus pagas, al sobrevenirle enfermedad y no poder servir, nombra en su lugar a Domingo Rodríguez de Argüello, vecino de Candas (Asturias) y lo fía por ser forastero.

AHPC, prot. 1.701 (1599), doc. 63-64.

1599/12/05. Castro Urdiales

Andrés de Quintana, alcalde mayor, por cuanto para servir en los galeones nuevos hechos en Bilbao para la Jornada de Inglaterra, el pasado 15 de marzo se habían alistado distintas personas, entre ellos Pedro de Obares, vecino de Ontón, de 29 años, con una señal sobre la ceja izquierda, y cobrado al contado a cuenta de sueldo y ventaja 20 ducados, ausentándose luego; para dar un castigo ejemplar, otorga 
poder al alguacil mayor para prenderlo y poner en la red de la cárcel como desertor al servicio real y que restituya los 20 ducados.

AHPC, prot. 1.701 (1599), doc. 183.

\section{9/12/23. Castro Urdiales}

Francisca de Vitoria, mujer de Pedro de Obares, vecina del concejo de San Martín de Ontón, dice que éste se había embarcado, tras alistarse en la villa de Portugalete, en el galeón del capitán Julián de la Sierra, con licencia, para ir a San Sebastián y que en el ínterim partieron los galeones, razón por la que no había podido seguir viaje, y llevaba preso ya 3 semanas.

La mujer consigna los 20 ducados en persona abonada y pide soltura de la cárcel, dando fianzas. Fianzas.

AHPC, prot. 1.701 (1599), doc. 184

1604/10/30. Castro Urdiales

Pedro Fernández de Trasgallo, como principal, y García de Amor, como fiador, avalan a Juan de Trasgallo, hijo de Pedro, que se había alistado en la armada del general Martín de Bertendona, cobrado 13 ducados y se había vuelto de Lisboa.

Estaba preso, había devuelto el adelanto y ahora daba fianzas para que lo soltasen.

AHPC, prot. 1.704 (1604), fol. 179.

\section{6/01/02. Castro Urdiales}

Pedro de Somolusa y su mujer, María de Gari, como principales, y Martín de Liendo el mayor, vecinos de Castro, se obligan a pagar al veedor Diego de Noja Castilla 563 reales y 3 cuartillos que Pedro había recibido de sueldo y socorro para asistir a los galeones y armadas reales, no habiendo comparecido.

AHPC, prot. 1.710, fol. 688-689.

1617/01/08. Castro Urdiales

Juan de la Herrera y Catalina de Camus, vecinos de Castro, por cuanto Juan se había alistado como marinero en la armada real y se había vuelto por razones particulares antes de ser despedido, para no ser prendido se obliga a presentarse en Santander cuando fuere llamado.

El proveedor le havia mandado prender y sin proceder contra él a mayor castigo por causas que a ello le habian movido.

AHPC, prot. 1.709 (1617), doc. 9.

\section{7/08/23. Castro Urdiales}

Santiago de Rúa Herrera, caballero de Santiago, proveedor de armadas en las Cuatro Villas y castellano del castillo de Ano, por cuanto Francisco de Carmona, vecino de Portugalete, se había alistado para servir en la armada y tras recibir 24 ducados, para incorporarse a la misma, no había comparecido, comunica a Martín del Río, vecino de Castro, su fiador, que pague dicha cantidad.

Martín se allana y recibe del alguacil del proveedor, Juan de Salas, carta de pago. Sigue carta de pago del mismo día.

AHPC, prot. 1.709 (1617), doc. 95.

Nota sobre las ilustraciones recogidas en este trabajo. El retrato de Felipe II procede del incípit de una ejecutoria de hidalguía de un caballero extremeño de 1565 , de propiedad particular, a cuyo dueño agradezco las facilidades dadas para fotografiarlo y mostrarlo aquí. Por su parte, las reproducciones de los navíos proceden de la Sala de Barcos del Palacio Nacional de Sintra (Portugal), donde están pintadas sobre tabla en la bóveda naves portuguesas, holandesas y turcas. Todas las fotografias son de mi autoría. 